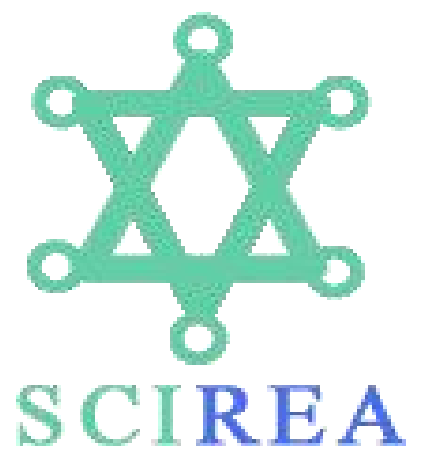

SCIREA Journal of Sociology

http://www.scirea.org/journal/Sociology

December 9, 2021

Volume 5, Issue 6, December 2021

https://doi.org/10.54647/sociology84691

\title{
The Legacy of the Hohenzollern
}

\section{Robert C. Moore}

Free Univerity of Berlin

Email: rcm31963@gmail.com

\begin{abstract}
Currently there is lively debate going on in Germany about the Hohenzollern legacy that is focused on the topic, if Crown Prince Wilhelm, and the family in general have supported National Socialism or not. When in November 2019 the four reports regarding the Hohenzollern claims for their 'lost' properties in former East Germany were made public, several historians since then have participated in a debate, that went from the material claims to examine the 'expert opinions' called 'reports' by historians for and against these claims, addressing a German law, that would exclude any claims of compensation, if Crown Prince Wilhelm had 'significantly advanced' the Nazis or not. The problem with these reports called Gutachten in German, equivalent to a neutral 'appraisal', is that specifically those in favor of the Hohenzollern claims, are anything but 'neutral', advancing arguments that are trying to excuse and justify the Crown Prince' support of the Nazis. This essay is examining the four reports for the first time and showing the differences in providing the reader with the historical context, that is specifically missing in those 'expert opinions' that are in favor of the Hohenzollern demands. Discussing the relevant issues along seven topics the author is trying to show the deficiencies of the reports and is interested to set the historical record straight
\end{abstract}


correcting the distortions and adding information that has been left out to boost the position of the Hohenzollern family in their fight with the Federal Government in Germany.

Keywords: Hohenzollern, Expert Opinion, Distortions, Crown Prince Wilhelm, Nazi seizure of Power

\section{Introduction}

Although mostly forgotten, the heirs of Kaiser Wilhelm II. and their claim to receive compensation for formerly owned properties has recently become a focus of a controversial discussion in Germany debating the involvement of the Hohenzollern family with the NSmovement. The debate to get compensation for properties previously located in East Germany merged into a discussion about the legacy of the Kaiser and his family and if they deserve compensation for their 'lost' holdings of the past. The topic of the debate ranged from the question if the claims of the heirs should be considered appropriate today in an age of democracy to a discussion of the issue why the current Government in Germany is negotiating with a "clan', whose legacy has been so disastrous for German history. One of the contributions even asked about the victims of the First World War and if they may have the right to ask for "reparations'2 if the Hohenzollern family wants to be compensated, implying that they might be responsible for unleashing the war.

\footnotetext{
${ }^{1}$ The term 'clan' is used by Bernd Stegemann, "Deutschlands erster Clan”, Cicero.de, July 30, 2019

${ }^{2}$ Sven F. Kellerhoff, "Und was ist mit den Toten des Ersten Weltkriegs, Prinz Georg Friedrich?", Die Welt.de, July 14, 2019
} 
The public debate about the Hohenzollern legacy originally initiated by historians ${ }^{3}$ is just at the beginning but was accelerated by the access to certain 'expert opinions' of historians as witnesses, which were used in the conflict between the Hohenzollern and the German state having been secret for a long time - now available to scrutinize regarding the activities of the Crown Prince and his support for Nazism. This topic also became an issue for the Committee on culture of the German Bundestag (Parliament) holding a hearing on January 29, 2020 and the Parliament debating the issue the same day. ${ }^{4}$ The discussion is still focusing somewhat narrowly on the current demands of the Hohenzollern and if these claims are legitimate. However, there is a more fundamental question lurking in the background: the question of continuity in German history between $1871-1945^{5}$ and the role of the conservative elites recognizing the fact that the claims of the Hohenzollern symbolizing that continuity provoking reflection about Germany's Sonderweg (special path) in the $20^{\text {th }}$ century. ${ }^{6}$

Part of that effort to rewrite history before and after 1945, is the Hohenzollern family and the quest to connect to the simple glory of the 'good old days' before the 'catastrophe' of 1945,

\footnotetext{
${ }^{3}$ The contributions by historians started in 2015 and accelerated with the publication of the four 'expert opinions' in November 2019, Stephan Malinowski, "Der braune Kronprinz", Die Zeit, August 13, 2015; Peter Brandt, Stephan Malinowski, "Ein Prinz im Widerstand?" Die Zeit, November 14, 2019; Stephan Malinowski, "Wir Stauffenbergs", Sueddeutsche Zeitung, August 7, 2019; Stephan Malinowski, "Die Selbstversenkung", Frankfurter Allgemeine Zeitung (hereinafter cited as 'FAZ.net'), July 22, 2019; Norbert Frei, "Die Hohenzollern deuten ihre Geschichte brachial um", Sueddeutsche Zeitung, Aug. 21, 2019; Christian Staas, "Der Kronprinz war ein reaktionaerer Opportunist", Interview mit Heinrich A. Winkler, Die Zeit, November 12, 2019; Richard Evans, "Das Gewissen eines Gutachters", FAZ.net, December 10, 2019; Winfried Suess, "Entschaedigung fuer die Preussen-Familie waere moralisch schwer begruendbar", Schaumburger Nachrichten, August 12, 2019; Ulrich Herbert, "Vier Gutachter, ein Kronprinz und die nationale Diktatur", FAZ.net December 1, 2019; David Motadel, "What do the Hohenzollern deserve?, New York Review of Books, March 26, 2020; Christopher Clark, "Helping Hitler", an Exchange, also a reply by David Motadel, New York Review of Books, April 9, 2020; Anja Reinhardt, "Weichgezeichnetes Kaiserreich", Interview mit Eckart Conze, Deutschlandradio Kultur, July 12, 2020; Eva Schlotheuber, Eckart Conze, "Die Ehre der Familie", FAZ.net, September 9, 2020; Karina Urbach, "Useful Idiots: the Hohenzollern and Hitler", in: Historical Research, 93 (261) 2020, 526-550; Andreas Kilb, "Kaiserbanner unterm Hakenkreuz", in: FAZ.net, 20. 5. 2021
}

\footnotetext{
${ }^{4}$ Speeches and statements during both events on Jan. 29, 2020 can be watched on video at 'parliamentary TV' at www.bundestag.de/parlamentsfernsehen; see also, "Bekommen die Hohenzollern, was sie wollen?" Frankfurter Allgemeine Zeitung, January 30, 2020; Jens Bisky, "Die Gefahr, dass alle am Ende verlieren", Sueddeutsche Zeitung, Jan. 30, 2020; Dirk Kurbjuweit, "Naeher waren sich Union und Rechtspopulisten selten," Spiegel.de, Jan. 16, 2020

${ }^{5}$ Joern Leonhard, "Sperrige Wiedergaenger", FAZ.net, December 21, 2019

${ }^{6}$ Regarding the discussion of the Sonderweg thesis and its validity, Juergen Kocka, "German History before Hitler: The Debate about the German Sonderweg", Journal of Contemporary History 23, no. 1 (1988): 3-16; Georg G. Iggers, "Review of Bernd Faulenbach, Ideologie des deutschen Weges", History and Theory 22, no. 1 (1983): 74-83; Geoff Eley, David Blackbourn, "The peculiarities of German History, an Interview", German History 22, no. 2 (2004): 229-245; Juergen Kocka, "Der 'deutsche Sonderweg' in der Diskussion" [The Discussion about the German special Path], German Studies Review 5, no. 3 (1982): 365-379; Hartwig Spenkuch, "Vergleichsweise besonders? Politisches System und Strukturen Preußens als Kern des 'deutschen Sonderwegs'" [Comparatively special? Political system and structures of Prussia as the core of the 'German Sonderweg'], Geschichte und Gesellschaft 29, no. 2 (2003): 262-293; Heinrich A. Winkler, "Der lange Schatten des Reiches" [The long Shadow of the Reich], Merkur 56, no. 635 (2002): 221-233
} 
discounting its share of the 'dark years' and dazzling the public with the alleged 'glamour' of the years before 1914. But the claim towards previously expropriated real estate, the demand for objects of art still on loan to German museums and a right to live rent-free in one of their former castles $^{7}$ as well as a legal muzzle ${ }^{8}$ for historians, who did not follow the Hohenzollern's line of argument, brought back the ugly tale of the family's legacy and the question of continuity in German history. The latest twist in this saga is the threat by the Hohenzollern family, if both parties to the conflict cannot agree to a deal, the Hohenzollern may pull back those objects of art that are on loan to German museums and display them in one of their own institutions trying to blackmail the German State. ${ }^{9}$ Meanwhile the Hohenzollern legal measures against historians amount to at least 70 cases $^{10}$ and the German associations of historians has put up an extensive website to inform the public about the Hohenzollern and the legal issues. ${ }^{11}$

The current head of the Hohenzollern family - as he confirmed in a recent interview ${ }^{12}$ - favors a description of history, and praises those historians, that will - like the authors of the reports

\footnotetext{
${ }^{7}$ Nikolaus Bernau, "Hohenzollern wollen abkassieren - hinter den Kulissen herrscht blanke Gier", Frankfurter Rundschau, July 24, 2019; idem., "Erneute Hohenzollern Besitzansprueche - warum gerade jetzt?", Interview, MDR-Kultur, July 15, 2019; Scott McLean, Nadine Schmidt, "Germany's ex-royals want their riches back, but past ties to Hitler stand in the way", CNN.com, September 26, 2020

${ }^{8}$ The Hohenzollern have sued several historians and media outlets to curb their statement legally, Julia Koeppe, "Hohenzollern gegen Historiker, der 250.000 Euro Satz", Spiegel.de, January 25, 2020; Klaus Wiegrefe, "Historiker wehren sich gegen juristischen Feldzug der Hohenzollern", Spiegel.de, December 13, 2019, Hans Monath, "Hohenzollern prozessieren weiter", Tagesspiegel, February 23, 2020; McLean, "Germany's ex-royals", CNN.com talks about the legal case against the historian Eckart Conze, who has said publicly that the Hohenzollern tried to suffocate the public discussion; now the Hohenzollern are getting help from some neoconservatives, who consider that the majority of historians in Germany want to usurp the Deutungshoheit (interpretative sovereignty), Andre Postert, "Geschichte vor Gericht", Cicero.de, September 17, 2020; Patrick Bahners, "Verbandspolitik", FAZ.net, September 17, 2020; Nicole Dittmer, "Das ist schon eine ziemliche Drohkulisse", Interview with Eva Schlotheuber, Deutschlandradio Kultur, September 9, 2020; Klaus Wiegrefe, "Der Prozesshansel", in: Der Spiegel No. 9, 28. 2. 2021; Patrick Bahners, "So schnell schiessen die Anwaelte der Preussen", in: FAZ.net, 17. 6. 2021
}

9 Sebastian Engelbrecht, "Kultursenator Lederer: 'Das klingt mir eher wie eine Drohung", in: Deutschlandradio.de, February 15, 2021

10 Klaus Wiegrefe, "Herr Prinz von Preussen lehnt sich sehr weit aus dem Fenster", Interview with Sophie Schoenberger, in: Spiegel.de, 14. 6. 2021

11 The website was created by Sophie Schoenberger, a professor of law at Duesseldorf University, https:/www.historikerverband.de/verband/veranstaltungen/die-klagen-der-hohenzollern-eine-

dokumentation.html

12 Patrick Bahners, Jan Bachmann, "Wir wollen nicht mehr scheinen, als wir sind", Interview mit Georg Friedrich Prinz von Preussen, FAZ.net, November 9, 2018, who described his view of the origins of the First World War as follows: "By examining the currents and political movements that have worked for decades on the event of the outbreak of war, a much more differentiated picture emerges regarding the question of guilt. (...) There are many reasons for the outbreak and the course of the First World War. In the meantime, research is moving away from the "sole guilt' of the former government or even the emperor. And I think that is justified." (all translations by author except otherwise noted) 
they hired - minimize the footprint of their ancestors from the unleashing of the first World War in 1914 to the activities of the Crown Prince in supporting Hitler seizing power in 1933. They prefer the type of 'history' ${ }^{13}$, as they facilitate in their own publications - anecdotal and full of 'glorious' pictures - that conform to their interest of a glamourous and apolitical past, being in contradiction with real events. Those historians that are set out to re-interpret German history in favor of the Hohenzollern having recently demonstrated their true allegiances, asking for sympathy of Crown Prince Wilhelm and his family who is pictured as beleaguered by relentless critics of the German Sonderweg. ${ }^{14}$

\section{Gutachten vs. Report}

The central issue of the current discussion is the question - according to a German law from $1994^{15}$ - if the Hohenzollern family and their ancestors, Wilhelm II. and his sons, 'significantly advanced' (erheblichen Vorschub leisten) National Socialism to reverse the unwelcomed developments of the Weimar Republic. All of this became the topic of discussion when the Hohenzollern heirs demanded compensation for their 'lost' properties, which forced them to look at their own history denying that their ancestors had anything to do with the 'ghosts' of the past, claiming that they had resisted the NS-movement before it came to power. To achieve this objective, they hired historians to act as crucial witnesses issuing an 'expert opinion' in support of these claims, that is called Gutachten in German.

And this is where the problem starts: the term Gutachten in German is more specific than the term 'report' in English and should be rather translated as 'appraisal', which means to give an

\footnotetext{
${ }^{13}$ William H. McNeill, "Mythhistory, or Truth, Myth, History, and Historians", American Historical Review 91, no. 1 (1986): 5: "Historians are therefore under perpetual temptation to conform to expectation by portraying the people they write about as they wish to be. A mingling of truth and falsehood, blending history with ideology, results."

${ }^{14}$ Benjamin Hasselhorn, "Und ewig gruesst der Sonderweg", Cicero.de, July 30, 2019; see also, "Wenn es um den Adel geht, scheint es in Deutschland keine Hemmungen zu geben", Neue Zuercher Zeitung, December 11, 2019; Hans-Christoph Kraus, "Das erklaerte Feindbild der NSDAP waren auch die Hohenzollern - weshalb man der Verlockung einer Abrechnung mit dem letzten deutschen Kronprinzen widerstehen sollte" [The declared enemy of the NSDAP was also the Hohenzollern - which is why one should resist the temptation to settle accounts with the last German crown prince], Neue Zuercher Zeitung, February 6, 2020; Niklas Weber, "Wie eng Konservative und Rechtsradikale verstrickt sind" [How close Conservatives and Right-wing Radicals really are], Sueddeutsche Zeitung, March 3, 2020; Ulrich Schlie, Thomas Weber, "Historiker entlasten den Hohenzollern Prinzen" [Historians exonerate the Hohenzollern Prince], Welt.de, April 15, 2021; Patrick Bahners, "Erheblich, das heisst nicht ganz unbedeutend" [Substantially, that is not entirely insignificant], FAZ.net, April 19,2021

${ }^{15}$ Regarding the Entschädigungs- und Ausgleichsleistungsgesetz [Law of Compensation] from 1994, there are several decisions by the high courts in Germany before and after, Bundesverfassungsgericht, 1 BvR 1170, 1174, 1175/90; Bundesverwaltungsgericht, 3 C 20.04; 8 B 1.17
} 
independent opinion on a certain type of transaction. A Gutachter in German is supposed to be a neutral 'appraiser' that is issuing a third party 'appraisal' to provide independent information that is not supposed to be in favor of the claims of one of the parties. In the case of the Hohenzollern the 'neutral' term Gutachten in German was used for a report that is not neutral: the authors were asked by the attorneys of either side to write up a report according to the legal framework of the law and give an 'expert opinion' in favor of the respective party.

The neutral term Gutachten in German is a misnomer covering up the party affiliation. It seems more appropriate to call these reports 'opinions' instead of Gutachten, because they are designed like legal briefs with historical examples that are set to prove a given point and should not be treated as 'appraisals' that were 'independently' conceived and written. The reports in question and their specific arguments are not designed to be 'open-ended' considering that the authors were hired to argue for a certain point of view. Christopher Clark's report is the best example for the subordination of historical evidence to legal requirements, that are expected to be answered in a certain way - in this case - denying any support of Crown Prince Wilhelm towards the Nazis and make the former look as harmless as possible.

But historians should also know that it is not inevitable to draw specific conclusions from the presentation of factual events ${ }^{16}$, and to do so may be a misinterpretation because conclusions logically have nothing to do with facts. ${ }^{17}$ Historians can claim that they have derived their conclusions from the facts at hand but - as the four reports show and confirm - different conclusions are possible because they are independently drawn from the factual basis. Somebody who is very fond of Germany and its elites, will always excuse the Hohenzollern, while somebody on the opposite will come to a different conclusion. But it is unscientific to base a presentation of facts and its judgements purely on sympathies or antipathies for a certain subject. Scientist need to give reasons and they should somehow match the factual basis their drawing on. Especially in the case of Clark's report it seems very questionable to present the negative facts about the Crown Prince but ignore them when the time comes to draw a conclusion. In a case of an 'appraisal' - as Richard Evans ${ }^{18}$ has pointed out -

\footnotetext{
${ }^{16}$ Max Black, "The Gap Between 'Is' and 'Should', Philosophical Review 73, no. 2 (1964): 165-181; John Searle, "How to Derive "Ought" from "Is", Philosophical Review 73, no. 1 (1964): 43-58; Rachel Cohon, Hume's Moral Philosophy, Stanford Encyclopedia of Philosohy (Stanford, CA 2018)

${ }^{17}$ David H. Fischer, Historians' Fallacies, Toward a Logic of Historical Thought (New York: Harper \& Row, 1970)

${ }^{18}$ Evans, Gewissen, FAZ.net, December 10, 2019
} 
historians should be careful signing up for a certain case, asking themselves if they can support the claims before them. Clark's report is an example for an 'expert opinion' that acknowledges the negative facts somehow, but is ignoring them when it is presenting its conclusions.

\section{Two sets of expert 'opinions' and the topics of inquiry}

To conform to the law of 1994 and avoid a refusal of their claims in court, the Hohenzollern family in 2011 looked around to search for a historian who would issue them a positive evaluation and negate the Crown Prince' support for National Socialism, considering that not only a potential compensation of 1.2 Million Euros (plus interest) was at stake but also about 7,000 objects of art on loan to public museums, altogether worth several hundred million Euros ${ }^{19}$. They didn't have to look that far, as a professor from Cambridge University, Christopher Clark, offered himself as the right choice, whose books on Wilhelm II. ${ }^{20}$ and Prussia $^{21}$ became back then all the rage, and who, as he himself has stated, does enjoy a foreigner 'bonus' and a certain amount of 'fools freedom'22 in Germany becoming a darling of all the national conservatives who long for a revival of Prussia and the Hohenzollern. ${ }^{23}$ And Clark had delivered what they had longed for: a picture of Prussia and the Kaiserreich that was cleansed of negative information, that could have provoked different conclusions.

Therefore, Clark, who has also received the prize of the Historisches Kolleg ${ }^{24}$ for his book on Prussia in 2010, naturally became a top candidate, considering his favorable view of the German elites before 1914 and the prestige being a professor from a leading university like Cambridge. He was identified a positive defender of the Hohenzollern legacy who would

\footnotetext{
19 Thorsten Metzner, "Hohenzollern erheben Ansprueche auf tausende bedeutende Kunstwerke", Tagesspiegel, July 13, 2019; Andreas Kilb, "Hohenzollern wollen in eines ihrer Schloesser zurueck", FAZ.net, July 24, 2019

${ }^{20}$ Christopher Clark, Wilhelm II., Die Herrschaft des letzten deutschen Kaisers (Muenchen: DVA, 2008) [engl. original, Kaiser Wilhelm II, Life in Power (London 2000)]

${ }^{21}$ Christopher Clark, Preussen, Aufstieg und Niedergang 1600-1947 (Muenchen, DVA 2007) [engl. Original: Iron kingdom: The rise and fall of Prussia 1600-1947 (London: Penguin Books, 2006)]

22 Christopher Clark, "Preussenbilder im Wandel" [Changing Images of Prussia], Historische Zeitschrift 292 (2011): 307-321, 308: "Man genießt also einen Ausländerbonus und damit ein gewisses Maß an Narrenfreiheit." [engl. transl.: "So you enjoy a foreigner bonus and thus a certain amount of fool's freedom."]

${ }^{23}$ Motadel, "Hohenzollern", New York Review of Books

${ }^{24}$ See Clark receiving the Prize of the Historisches Kolleg, Dokumentation zur Verleihung des Preises des Historischen Kollegs an Professor Dr. Christopher Clark [Documentation on the award of the prize of the Historisches Kolleg], November 5, 2010; also the Laudatio by Helmuth Neuhaus, "Laudatio auf Christopher Clark", Historische Zeitschrift, 292 (2011): 297-305
} 
probably not disappoint a client in providing the necessary Persilschein ${ }^{25}$, a 'getting out of jail free card'. When the deal was struck, Clark, of course, has stated the opposite: he claims in an interview in 2019 that he - from the beginning - has told the Hohenzollern attorneys, that his assignment could only be open-ended. ${ }^{26}$ Although Clark may have lately made some amends towards the overwhelming evidence of Wilhelm's interactions with the Nazis (claiming as an excuse that 'new' evidence was discovered lately), he is not retracting his overall judgements in his report of $2011 .^{27}$

The calculation paid off in the short run: the local Government agency in Beeskow (State of Brandenburg) issued a Vorbescheid (preliminary notice) of approval in January 2014 based on Clarks report on Crown Prince Wilhelm. ${ }^{28}$ It is not surprising that Clark's conclusion in his report reads that the Crown Prince (although he was a "man of a reactionary mind" 29 ) did not 'significantly advance' National Socialism, his actions were not to help spreading the NSmovement nor was he helping to suppress resistance against the NS-regime. His random actions of support were not facilitated on a steady basis, although Clark himself provided a lot of evidence to the contrary. What the Hohenzollern heirs on the other hand were not counting on, was, that the Minister of Finance of the State of Brandenburg did not buy into Clark's conclusions and ordered two additional 'appraisals' by the historians Peter Brandt and Stephan Malinowski. ${ }^{30}$ Both stated in their reports - in line with the overwhelming evidence they provided - that Wilhelm's actions without a doubt 'significantly advanced' the NS-

25 This term was used by the historian Wolfgang Wippermann in his Interview with Susanne Fuehrer, "Antidemokraten nicht fuer ihr Handeln belohnen", Deutschlandfunk Kultur, February 26, 2014

${ }^{26}$ Klaus Wiegrefe, “The Man was a Twit. Historian Christopher Clark on the Hohenzollern Dispute”, Spiegel.de, October 26, 2019

${ }^{27}$ Andreas Kilb, "Wilhelm wollte Hitler nicht zaehmen, Interview with Christopher Clark", FAZ.net, November 4, 2020

${ }^{28}$ Katharina Wiechers, "Der Adel soll jetzt Geld zurueckbekommen", Potsdamer Neueste Nachrichten, February 25, 2014; Klaus Wiegrefe, "Prinz mit Schuss", Der Spiegel no. 37 (2014): 38-40

${ }^{29}$ Christopher Clark, Hat Kronprinz Wilhelm dem nationalsozialistischen System erheblichen Vorschub geleistet? [Did Crown Prince Wilhelm significantly advance the National Socialist system?] (Cambridge, 2011) [quoted hereinafter as 'Clark, Report'], the report can be downloaded at www.hohenzollern.lol

30 Peter Brandt, Gutachten zur politischen Einstellung und zum politischen Verhalten des ehemaligen preussischen und reichsdeutschen Kronprinzen Wilhelm [Expert opinion on the political attitudes and behavior of the former Prussian and Imperial German Crown Prince Wilhelm] (Hagen, 2014): 70p.; Stephan Malinowski, Gutachten zum politischen Verhalten des ehemaligen Kronprinzen (Wilhelm Prinz von Preußen, 1882-1951) [Expert opinion on the political behavior of the former Crown Prince] (Edinburgh, 2014): 107 p. (quoted hereinafter as 'Brandt, Report', and 'Malinowski, Report'); both can be downloaded at www.hohenzollern.lol; Stepan Malinowski, Die Hohenzollern und die Nazis (Berlin: Ullstein, 2021) 
Movement which caused the government to issue a final decision to the Hohenzollern to be negative, prompting them to go to court to undo it in $2016 .{ }^{31}$

But the Hohenzollern heirs found another set of historians, who issued an extensive 'appraisal', that is to refute the findings of Brandt and Malinowski, pointing out that Crown Prince Wilhelm's activities were designed to prevent Hitler and the NS-Movement from getting to the levers of power and that he was also opposed to the regime after January 30 , 1933. The additional report by Wolfram Pyta and Rainer Orth ${ }^{32}$ wants to challenge the other historians with further arguments and new sources, to demonstrate that the Crown Prince not only did not support Hitler in his quest for power but was - together with Chancellor Kurt von Schleicher - actively set out to thwart the 'Fuehrer' and the NS-movement. As Richard Evans has pointed out, normally there is nothing wrong for historians to participate as an expert witness in trials and issue reports, but it is necessary in each case to look at the merits and think about if one may be asked to vouch for things that cannot be proven. ${ }^{33}$

And that is the decisive factor of an 'appraisal' a historian is asked to write. Is he free to deliver a report that is 'open-ended' meaning the outcome is not set from the beginning, or is he required with an eye on the client to perform a task that is constrained from the start and needs to confirm a foregone conclusion? In the case of the two reports in favor of the Hohenzollern, written by Clark and Pyta/Orth, this inquiry will demonstrate that they are following a pre-conceived conclusion, and that this restriction has limited the historical presentation to avoid unwelcome evidence that in the eyes of the reader could change those conclusions. No doubt that the other two 'reports', by Peter Brandt and Stephan Malinowski, may also suffer certain limitations (they seem incomplete), but they are different considering that they are not set out to limit the historical evidence to provide a restricted picture of the relevant events. They can argue with the historical evidence instead of going against it and do not have to distort their conclusions.

\footnotetext{
31 Thorsten Metzner, “Keine Steuermillionen fuer Hohenzollern”, Potsdamer Neueste Nachrichten, January 15, 2016

${ }^{32}$ Wolfram Pyta, Rainer Orth, Gutachten über die politische Haltung und das politische Verhalten von Wilhelm Prinz von Preußen (1882-1951), letzter Kronprinz des Deutschen Reiches und von Preußen, in den Jahren 1923 bis 1945 [Expert opinion on the political stance and behavior of Wilhelm Prince of Prussia (1882-1951), last Crown Prince of the German Empire and of Prussia, in the years 1923 to 1945] (Stuttgart, 2016), (quoted as 'Pyta/Orth, 'Report'): 157p., this report can also be downloaded at www.hohenzollern.lol; Wolfram Pyta, Rainer Orth, "Nicht alternativlos. Wie ein Reichskanzler Hitler haette verhindert werden koennen" [Not without an alternative, how a Chancler Hitler could habe been prevented], in: Historische Zeitschrift 311, 2021

${ }^{33}$ Evans, "Gewissen", FAZ.net, December 19, 2021
} 
The reports by Brandt and Malinowski are trying to enlarge the historical evidence in showing that there were plenty of incidents where the Crown Prince interacted with the NS-movement, while the reports of Clark and Pyta/Orth are trying to limit and reduce the evidence to shorten the scope of inquiry and avoid unwelcome discussions. As we will see, Clark and Pyta/Orth not only limit the presentation of historical facts but are trying to advance a thesis - either the Crown Prince was a harmless Mitlaeufer or his efforts were geared to prevent Hitler from coming to power - which is - given the historical record - a distortion of what has happened that only suits the general argument of their client. Only if the other reports by Brandt and Malinowski are added, the reader will get a more complete picture with crucial information that seems highly relevant for the understanding of the Crown Prince' activities between 1930 and 1945.

A new study by Lothar Machtan ${ }^{34}$ has also added new evidence that points out again - like Brandt and Malinowski - how much the Crown Prince has supported Hitler and National Sozialism. The only odd thing about Machtan's study is the fact that this study was supported by the current head of the Hohenzollern family, Prinz Georg Friedrich von Preussen, who has paid for the research, has rewarded Machtan with a 5-figure salary ${ }^{35}$ (that is not disclosed) and that Machtan - at the end of his study - is giving a special thanks to the Prince. ${ }^{36}$ In his introduction Machtan is claiming that an "unbiased consideration" and not a "moral evaluation" is at stake, but, it seems like his conclusions - slightly in favor of the Crown Prince - are already build in. Not that he his shy to furnish "generalizable conclusions" (whatever that means), there are several characterizations of Wilhelm, that seem in contradiction to the materials that he has found in the archives, which by itself does not cast any doubt that the Crown Prince supported Hitler. But here and there he manages to throw in certain remarks that put his depiction of what happened in question and can let to different conclusions. It starts at the beginning, where he speaks of a "political entanglement"37 (Verstrickung) of the Crown Prince and regarding the results of his inquiry he points out "I

\footnotetext{
${ }^{34}$ Lothar Machtan, Der Kronpirnz und die Nazis [The Crown Prince and the Nazis] (Berlin: Duncker und Humblot, 2021)

${ }^{35}$ Klaus Wiegrefe, "Der Kronprinz und der liebe 'Don Adolfo'”, in: Der Spiegel No. 32, August 6, 2021, is also puzzled, that Georg Friedrich von Preussen has paid for a study that has brought in further evidence against the Crown Prince und is assuming that Georg Friedrich is trying to boost his image with a critical study, considering that all the lawsuits against historians since 2015 are not helping his main case to get restitution

${ }^{36}$ Machtan, Kronprinz, 295-296

${ }^{37}$ Machtan, Kronprinz, 10, 240
} 
don't know if it really happened like this" or that "other narrative perspectives are possible, and therefore different results", and that "judgemental certainty" cannot be achieved. ${ }^{38}$

Machtan sees rather a "conglomerate of fear, cowardness, and perhaps naïve hope" and that Wilhelm in his propaganda for the 3 . Reich became - instead of a conscious supporter out of convictions - a "fellow traveler" (Mitlaeufer), a reactionary opportunist, with similarities just like other Germans at the time, who felt like "lighthouses" of political culture, but became effectively, in the case of the Crown Prince, with their kow-tow to Hitler the death knell of the monarchy in Germany. ${ }^{39}$ Machtan likes to think in terms of "trials and tribulations" (Irrungen und Wirrungen $)^{40}$ and emphasizes that even Hitler - before January 1933 - was exposed to "changing groups of people, who helped each others careers (Seilschaften), intrigues, and strokes of good and bad luck without an overarching determinant" 41 . According to Machtan, all the events, that led to transfer of power to Hitler, actually had no direction, as if Hindenburg's acquiescence happened out of a process of decision making, that had all the alternatives exhausted. There is another issue that constantly is part of Machtans depiction of the Crown Prince: that Wilhelm's actions for the Nazis were just based on opportunism, that he was constantly 'adapting his activities to the whims of the Fuehrer' ("sein Faehnchen nach dem Wind haengen") making it look like as if the Crown Prince had no convictions and therefore thought differently about Hitler's program then he would otherwise admit (“zumindest optisch") ${ }^{42}$.

Machtan is trying to ascertain an ambiguity ("Doppelboedigkeit") in Wilhelms public appearances ${ }^{43}$, that seems artificial and unwarranted, and his doubts regarding the Crown Prince actions, that he has 'significantly advanced' National Socialism and Hitler ${ }^{44}$, is a case, considering the evidence he is providing, that is only 'open' to him. In his conclusions Machtan is following not the evidence he has provided but the needs of his clients, who have paid his salary and will appreciate his 'unbiased considerations' that in the end wants to leave the conclusions to the decisions of the court. At the end of the day the Hohenzollern want to

\footnotetext{
${ }^{38}$ Machtan, Kronprinz, 10

${ }^{39}$ Machtan, Kronprinz, 242

${ }^{40}$ Machtan, Kronprinz, 10

${ }^{41}$ Machtan, Kronprinz, 242

${ }^{42}$ Machtan, Kronprinz, 216

${ }^{43}$ Machtan, Kronprinz, 217

${ }^{44}$ Machtan, Kronprinz, 244-245
} 
win their case in court and need the help from a respectable historian like Machtan. The way he is approaching the Crown Prince and the Nazis - with a thorough search of all the German archives leaving no stones unturned - is still more credible that the outright denials of Clark Pyta/Orth. Also, besides his sole focus on the period between 1931 and 1935, Machtan is leaving out an important chapter in which the Crown Prince - despite his negative experience in 1934 - still showed enthusiastic support when Hitler from 1938 on invaded neighboring countries in Europe, a factor, that shouldn't be left out when it comes to judging Wilhelms support for the 'Fuehrer'.

With these conclusions - despite all the new evidence provided - Machtan in his results is following Clark, who also saw the Crown Prince just as a 'fellow traveller'(Mitlaeufer) emphasizing his 'fatal entanglement' with the Nazis and his insignificant role in Hitler's seizure of power. Machtan wants to start the discussion about all this now, but the discussion begun two years ago, and the question if the Crown Prince has supported Hitler and the Nazis or not seems for the public already decided. ${ }^{45}$ Prince Georg Friedrich, as the head of the Hohenzollern, will feel very comfortable in having Machtans study as a third 'appraisal' (in their favor), that sees randomness in the actions of the Crown Prince and Hitler and explicitly refusing to conclude that the Crown Prince supported National Socialism or that he was 'significantly advancing' it, stating, that it is better for historians to leave this judgement to the courts. ${ }^{46}$

Therefore the following inquiry is set up to discuss the relevant issues discussed in the four reports. It will accentuate the differences between them and demonstrate how they are providing or omitting the relevant information that need to be added to complete the historical picture. ${ }^{47}$ Therefore, the two sets of 'appraisals' in this case should not be judged by the stated

\footnotetext{
${ }^{45}$ Machtan, Kronprinz, S. 245; Andreas Kilb, "Die braune Blume der Monarchie”, FAZ.net, August 11, 2021

${ }^{46}$ Machtan, Kronprinz, 244-245

47 The historical context of this inquiry is based on the following studies, Heinrich A. Winkler, Weimar 19181933, die Geschichte der ersten deutschen Demokratie [Weimar 1918-1933, the History of the first German Democracy] (Muenchen: C. H. Beck, 2018): 375-616; Hans Mommsen, Aufstieg und Untergang der Republik von Weimar, 1918-1933 [Ascent and Downfall of the Republic of Weimar] (Berlin: Ullstein, 1998): 483-644, Hans Mommsen, Von Weimar nach Auschwitz, Zur Geschichte Deutschlands in der Weltkriegsepoche [From Weimar to Auschwitz, the History of Germany during the Epoch of the World Wars] (Stuttgart: DVA, 1998); Wolfram Pyta, Hindenburg, Herrschaft zwischen Hohenzollern and Hitler [Hindenburg, Rule between Hohenzollern and Hitler] (Muenchen: Siedler, 2007): 555-874; Ian Kershaw, Hitler 1889-1936 (Stuttgart: DVA, 1998): 399-662; Karl-Dietrich Bracher, Die Aufloesung der Weimarer Republik: eine Studie zum Problem des Machtverfalls in der Demokratie [The dissolution of the Weimar Republic: a study on the problem of the Decline in Power in a Democracy] (Villingen: Ring Verlag, 1971, 5 ${ }^{\text {th }}$ Print.): 205-638; Volker Hentschel, Weimars letzte Monate, Hitler und der Untergang der Republik [Weimar's last months, Hitler and the downfall of the Republic] (Duesseldorf: Droste, 1978): 31-101; Gerhard Schulz, Von Bruening zu Hitler, Der Wandel des politischen Systems in Deutschland 1930-1933 [From Bruening to Hitler, the Change of the Political System in
} 
conclusions, but by the evidence and the historical context they are providing.

\section{The Presidential elections of 1932}

Beginning with the presidential elections of 1932, Clark's report is providing the reader with a picture that is constrained from the start, only covering the second ballot, that the Crown Prince stated publicly on April 3, 1932, that he believed in a united 'national front' and therefore would vote for Adolf Hitler, leaving out the whole story how the Wilhelm got to this point. And - focusing on the usefulness of his activities for the Nazis - Clark sees no signs that this statement helped Hitler to get any additional votes and asserts that there was nobody else except the Crown Prince, who believed that his proclamation to vote for Hitler in 1932 had any impact on the public. Wilhelm's bragging two years later in his letter to Lord Rothermere, where he is stating - compared to the first ballot - that his proclamation brought in two million more votes to the Fuehrer, Clark considers as exaggerated and pure speculation. ${ }^{48}$

Pyta/Orth concur and add another argument in favor of the Crown Prince that is surprising: because Hitler had lost the election at the second ballot Wilhelm's recommendation had no impact whatsoever. They point out that his public image as an 'aristocratic reactionary' may have even had a negative effect on 'normal' voters, because the recommendation of the Crown Prince may have cost Hitler more votes than it brought in. ${ }^{49}$ In short, they want to demonstrate that any conclusions about the effectiveness of Wilhelm's support is pure speculation and therefore it is also possible to conclude that Hitler and National Socialism may even were at a disadvantage. For Brandt/Malinowski the Crown Prince's statement of support is a home run, even if Wilhelm's bragging about him having brought Hitler the 2 Million votes is discounted.

In many ways, the Presidential election of March 1932 constituted a special event against the republic. First, looking at the candidates (compared to 1925) the choice was only limited between different shades of 'black'. Hindenburg, Duesterberg, and Hitler were all determined

Germany, 1930-1933] (Berlin: Walter de Gruyter, 1992); Thilo Vogelsang, Staat, Reichswehr und NSDAP, Beitraege zur deutschen Geschichte 1930-1932 [State, Army and NSDAP, Contributions to German History, 1930-1932] (Stuttgart: DVA, 1962): 65-404; Die deutsche Staatskrise 1930-1933, Handlungsspielraeume und Alternativen [The German State Crisis, 1930-1933, Scope of Action and Alternatives], ed. Heinrich A. Winkler (Muenchen: Oldenbourg, 1992); Volker Ullrich, Adolf Hitler, die Jahre des Aufstiegs [Hitler, Years of Ascent] (Frankfurt/M.: Fischer, 2013): 324-420, 458-567; Volker Ullrich, Adolf Hitler, die Jahre des Untergangs [Hitler, Years of Downfall] (Frankfurt/M.: Fischer, 2018): 19-333

${ }^{48}$ Clark, Report, 3, 9-10

${ }^{49}$ Pyta/Orth, Report, 45-56 
to abolish the Republic ${ }^{50}$, while Thaelmann, the candidate of the Communist Party, was not a serious alternative to sustain or rejuvenate democracy. The parties of the Weimar coalition from 1919 (SPD, Zentrum, BVP, DVP), in contrast to $1925^{51}$, had no candidate of their own and supported Hindenburg as the lesser evil ${ }^{52}$, as an assumed alternative to Hitler. Hitler by himself had to overcome an additional problem, because his status would not allow him to run for President. He had to become a naturalized German citizen, a process that had failed in the past, but was achieved now in the last minute by his comrades in the small state of Braunschweig, where the NS-party provided the Minister of the Interior. Hitler became a citizen of Germany because the Nazi-Minister Klagge appointed him overnight as a Regierungsrat in a governmental position. ${ }^{53}$

The politicians of the Weimar coalition were betting on a candidate of the Right, ${ }^{54}$ and that the future of democracy was left to Hindenburg, who was clearly opposed to the republican system he had served since 1925 . His ideal was a cabinet of 'national concentration' based on the forced unity of August 1914 that would be calibrated towards the elimination of the Parliament and an authoritarian regime like the one during the Kaiserreich. Or even worse, in appointing Hitler as a Chancellor on January 30, 1933, he helped to install a one-party dictatorship $^{55}$ forgetting his objections against Hitler he had brought up many times previously. ${ }^{56}$ Hindenburg's inclinations to appoint the leader of the largest faction in the

\footnotetext{
${ }^{50}$ Fredrick T. Birchall, "Republic is in Balance, Opponents of Hindenburg seek to overthrow Democratic Rule", in: New York Times, March 13, 1932

${ }^{51}$ Noel D. Cary, "The Making of the Reich President, 1925: German Conservatism and the Nomination of Paul von Hindenburg", Central European History 23, no. 2 (1990): 179-204; Peter Fritzsche, "Presidential Victory and Popular Festivity in Weimar Germany: Hindenburg's 1925 Election", in: Central European History 23, no. 2 (1990): 205-224

${ }^{52}$ Larry E. Jones, "Hindenburg and the Conservative Dilemma in the 1932 Presidential Elections", in: German Studies Review 20, no. 2 (1997): 235-259; Erich Matthias, "Hindenburg zwischen den Fronten 1932", in Vierteljahrshefte für Zeitgeschichte 8, no. 1 (1960): 75-84; Larry E. Jones, Hitler versus Hindenburg: The 1932 Presidential Elections and the End of the Weimar Republic (Cambridge, MA: Cambridge University Press, 2015): 357, states that Hitler was the real winner of the election in the long run, while Hindenburg's authority
} had been eroded

53 The details by Rudolf Morsey, "Hitler als braunschweigischer Regierungsrat", in: Vierteljahrshefte fuer Zeitgeschichte 8, no. 3 (1960): 419-448; Donald C. Watt, "Die bayrischen Bemuehungen um Ausweisung Hitlers 1924”, in: Vierteljahrshefte fuer Zeitgeschichte 6, no. 2 (1958): 270-280

${ }^{54}$ Wolfgang Pyta, "Hindenburg and the German Right", in: The German Right in the Weimar Republic, Studies in the History of German Conservatism, Nationalism, and Antisemitism, ed. Larry E. Jones (New York: Berghahn, 2014): 25-47

${ }^{55}$ Bracher, Aufloesung, 392-423

56 Hindenburg's objections to Hitler in August 1932, Walter Hubatsch, Hindenburg und der Staat, aus den Papieren des Generalfeldmarschalls und Reichspraesidenten 1878-1934 [Hindenburg and the State, from the Papers of the Field Marshal and President of the Reich, 1878-1934] (Goettingen: Musterschmidt, 1966), Doc. 87-88, 335-339, Doc. 88 (recorded by State Secretary Otto Meissner), 338: "By God, his conscience and the 
Reichstag were not really a surprise: before January 30, 1933 - leaving all the objections aside - he already commissioned Hitler in November 1932 to form a new government based on a parliamentary majority. That would not materialize because Hitler could not form an administration based on parliamentary majority without the help of the President granting him access to the 'emergency' powers to initiate new elections, that would have been necessary to rely on a majority of the Reichstag. ${ }^{57}$ At this point in time it would not work, because Hindenburg - compared to two months later - still refused to do that.

Chancellor Bruening's policies (as well those of his successors) were subjugated to the doctrine of the Primat der Aussenpolitik ${ }^{58}$ ('primacy of foreign policy') which meant in this case that all policies were subject to a process to overcome the Versailles order, ending reparations and reestablishing German sovereignty that included a new army and unlimited rearmament to become a great power again like France, Great Britain or the US. Bruening as a National Conservative - even during the economic crisis - was determined to follow a course of non-deficit spending to demonstrate to the Allies that he was doing all he could to fulfill Germany's obligations under the Versailles Treaty, hoping to demonstrate that economic circumstances required him to ask for an end to reparations. ${ }^{59}$ The Chancellor got progressively under fire and was only kept in office by Hindenburg, because of his usefulness in foreign policy hoping that he, in his ongoing negotiations with the Allies in Lausanne, would deliver the expected termination of reparations and the equality in armaments with France and Great Britain. ${ }^{60}$

fatherland, he could not be responsible for transferring all government power to one party, especially a party that was unilaterally opposed to dissenters. There are also a number of other reasons against this, which he does not want to explain individually, such as concerns about major unrest, the effects on foreign countries, etc."

${ }^{57}$ Hentschel, Weimar, 74-76; Bracher, Aufloesung, 580-586, Hubatsch, Hindenburg, Doc. No. 91-103, 345-366

58 The doctrine of the 'primacy of foreign policy' in Germany goes back to Ranke, Ernst-Otto Czempiel, "Der Primat der Aussenpolitik: Kritische Würdigung einer Staatsmaxime" ["The Primacy of Foreign Policy: critical appreciation of a state maxim], in: Politische Vierteljahresschrift 4, no. 2 (1963): 266-28; Heinrich Heffter, "Vom Primat der Aussenpolitik" [The Primacy of Foreign Policy], in: Historische Zeitschrift 171, no. 1 (1951): 1-20; Karl Dietrich Bracher, "Kritische Betrachtungen über den Primat der Außenpolitik" [Critical Reflections on the Primacy of Foreign Policy], in: Faktoren der politischen Entscheidung, Festgabe für Ernst Fraenkel zum 65. Geburtstag, ed. Gerhard A. Ritter and Gilbert Ziebura (Berlin: Walter de Gruyter, 1963): 115-148; Hans Rothfels, "Sinn und Grenzen des Primats der Aussenpolitik" [Meaning and Limitations of the Primacy of Foreign Policy], in: Aussenpolitik 6, no. 2 (1955): 277-285

59 One of the best descriptions of Bruening's economic policies see Ursula Buettner, "Politische Alternativen zum Brüningschen Deflationskurs. Ein Beitrag zur Diskussion über 'Ökonomische Zwangslagen' in der Endphase von Weimar'[Political Alternatives to Bruening's Path of Deflation, a Contribution to the Discussion about Economic Predicamanets], in: Vierteljahrshefte für Zeitgeschichte 37, no. 2 (1989): 209-251

${ }^{60}$ Heinrich Bruening, Memoiren (Stuttgart: DVA, 1970): 417-606 shows the process of his retreat 
One of the National Conservatives that demanded a cabinet that would initiate a further turn to right (that possibly included individuals from the Nazi Party) was Crown Prince Wilhelm. He had already sent letters to Hindenburg and the generals of the Reichswehr (Army) complaining about 'leftist' activities that needed to be curbed protesting against the rather mild ban on uniforms in $1931^{61}$. In this situation where the future of the republic was at stake, Wilhelm - after his own candidacy had failed - announced publicly on April 3, 1932, that he (at the second ballot) would vote for Hitler trying to boost the candidacy of the most rightwing candidate shunning the National Conservative Duesterberg. ${ }^{62}$ The Crown Prince' failed candidacy (which Clark and Pyta/Orth are not mentioning in their reports) was a strong indicator for Wilhelm's cooperation with Hitler. It is telling that his candidacy - three days before the deadline - was initiated by the NS-party member, Joachim von Ostau, who specifically flew to Munich to negotiate the terms of the candidacy with Hitler, Goebbels, Hess and Frick. ${ }^{63}$ Hitler's conditions for the candidacy were straightforward: his interest was focused on the current President to resign because they all thought Hindenburg would not run against a Hohenzollern Prince, and Wilhelm had promised to appoint him Chancellor ${ }^{64}$ after he would be elected.

The calculation behind this move was as follows: if Hitler also withdrew, Wilhelm at the second ballot would only face the communist candidate Ernst Thaelmann against whom - they all fairly assumed - he would win handsomely. Klaus Jonas has pointed out that Hitler even came to see the Crown Prince before the deadline on March 31, 1932 and advised him to become a candidate to throw off Hindenburg ${ }^{65}$. In a letter delivered by Ostau, Wilhelm is asking the Fuehrer and his party for support of his mission and to be the candidate of unity of the "national front" 66 , that as a conglomerate of right-wing parties had difficulties to agree on a common one. In other words: the whole candidacy depended on the support of the NS-

\footnotetext{
${ }^{61}$ Johannes Huerter, Wilhelm Groener, Reichswehrminsiter am Ende der Weimarer Republik, 1928-32 [Minister of the Reichswehr at the End of the Weimar Republic] (Muenchen: Oldenbourg, 1993): 320

62 Volker R. Berghahn, "Die Harzburger Front und die Kandidatur Hindenburgs fuer die Praesidentschaftswahlen 1932", in Vierteljahreshefte fuer Zeitgesschichte 13, no. 1 (1965): 64-82

${ }^{63}$ Wolfgang Stribrny, "Der Versuch einer Kandidatur des Kronprinzen Wilhelm bei der Reichspraesidentenwahl 1932"[The Candidacy of Crown Prince Wilhelm at the 1932 Presidential Election], in: Geschichte in der Gegenwart, ed. Ernst Heinen, Hans J. Schoeps (Paderborn, Schoeningh, 1972): 199-210, 201, 205-207

${ }^{64}$ Julius Friedrich, Wer spielte falsch? Hindenburg, Hitler, der Kronprinz, Hugenberg, Schleicher [Who is playing false? Hindenburg, Hitler, the Crown Prince, Hugenberg, Schleicher] (Hamburg: Laatzen, 1949): 12; Stribrny, "Kandidatur", 202

${ }^{65}$ Klaus W. Jonas, Der Kronprinz Wilhelm (Frankfurt/M.: Fischer, 1962): 224

${ }^{66}$ Jonas, Kronprinz, 226
} 
leadership and if the Crown Prince' emissary, former Field Marshal August von Mackensen ${ }^{67}$, would be able to convince Hindenburg to withdraw from the second ballot. It seems logical that Hitler actually only promoted the Crown Prince' candidacy to eliminate Hindenburg form the race knowing that it would be difficult for any candidate to beat him at the polls. A candidate - as Pyta/Orth are suggesting - who wanted to prevent Hitler from coming to power, would have refused to be part of this game, but Wilhelm acquiesced and stayed in the race until his father said 'no'. For Wilhelm none of the required prerequisites materialized and his candidacy had to be considered a failure, but even after that, Wilhelm did not give up and demonstrated that he was solidly in Hitler's camp. He wrote to one of the supporters of his failed campaign stating, "through the negotiations of late the relations between me and the leadership of the NSDAP were certainly consolidated". 68

Although Clark and Pyta/Orth try to downplay Wilhelm's public statement by merely questioning its effectiveness ${ }^{69}$ - leaving his motives aside - several historians have pointed out that the Crown Prince' vote for Hitler caused a public uproar and had a significant impact on the election. The National Conservative candidate Duesterberg who had received 2.6 million votes at the first ballot dropped out of the race and these votes became potentially available for either Hindenburg or Hitler. Although it may be difficult to assess the exact voter fluctuation, a detailed analysis of the different counties by Juergen Falter has shown that about 60 percent of former Duesterberg voters crossed over to Hitler, roughly 1.4 Million, 13 percent came from Thaelmann and the rest came from the non-voter pool, while Hindenburg received only 700,000 new votes. ${ }^{70}$ Even if we consider the Crown Princes's statement in his letter to Lord Rothermere in 1934, that he provided Hitler with 2 Million additional votes as an exaggeration, it seems logical that Wilhelm's public call to vote for Hitler - unusual as it was - must have had a significant impact on the electorate, and may have have swayed 1.4 Million Duesterberg voters to choose Hitler. ${ }^{71}$

\footnotetext{
${ }^{67}$ Stribrny, "Kandidatur", 203; Jonas, Kronprinz, 225; Theo Schwarzmueller, Zwischen Kaiser und Fuehrer, Generalfeldmarschall August von Mackensen (Paderborn: Schoeningh, 1996): 246-253

${ }^{68}$ Stribrny, "Kandidatur", 208

${ }^{69}$ Clark, Report, 12, 16-17; Pyta/Orth, Report, 53

${ }^{70}$ Juergen Falter, "The Two Hindenburg elections of 1925 and 1932: A total reversal of Voter Coalitions", Central European History 23, no. 2 (1990): 225-241, 236-241; for a further discussion of the different factors which influenced voter fluctuation and the reasons for that, Juergen Falter, Hitlers Waehler [Hitler's Voters] (Muenchen: C. H. Beck, 1991): 67-135, 325-373

${ }^{71}$ Jonas, Kronprinz, 231-232, Falter, Hitler's Waehler, 325-373
} 


\section{The SA-Ban and the 'national opposition'}

The next issue in the long line of Wilhelm's support for the Nazis, is the letter on April 14, 1932 he had sent to the Minister of the Interior and the Reichswehr, Wilhelm Groener. In this letter the Crown Prince informs Groener, a former member of the General Staff during the War, that he is concerned about the future of Germany, because he can only consider the ban on SA and SS in connection with the ban on uniforms on all paramilitary organizations as a "big mistake" and a 'danger' for the domestic peace in Germany. In addition, Wilhelm is pointing out that - as a result of the SA-ban - the 'wonderful' human material of the SAmembers' would be wasted and might also have a negative influence on vital foreign policy issues in the East. Therefore, Wilhelm is speculating about a 'dark' scenario of preventive war $^{72}$ - not unusual in right-wing circles at the time - where Polish forces might intervene against East Prussia and Danzig and could use this alleged 'weakness' to their advantage for an invasion of Germany. The Crown Prince is also aware of the lack of recruits at the Reichswehr and wants to save the members of the SA for future army divisions as part of the of the Reichswehr he would like to see increase. In short, Wilhelm is telling Groener that his SA-Ban ${ }^{73}$ - like the one on the uniforms - is doing severe damage to the country (domestically as well as internationally) and should not have been issued in the first place. ${ }^{74}$

Clark in his report is partially depicting the content of the letter but does not want to view it as an act of support or sympathy for the Nazis, rather as an expression of the so-called 'taming concept' of the conservatives we will address later. He is also stating that Wilhelm's letter had no impact on Groener considering that the SA-Ban was canceled by Franz von Papen, Bruening's successor two months later, and the Crown Prince' letter had nothing to do with the later repeal by Bruening's replacement. Therefore, Clark is concluding that the letter had no direct impact on the cancellation of the ban and should be considered negligible. In Clark's

\footnotetext{
72 The background of the 'preventive war' discussion, Zygmunt J. Gasiorowski, "Did Pilsudski Attempt to Initiate a Preventive War in 1933?”, in: Journal of Modern History 27, no. 1 (1955): 135-151

73 The primary sources on the SA-ban, Akten der Reichskanzlei. Die Kabinette Bruening I und II, 3 Vol., ed. Karl-Dietrich Erdmann [Files of the Reich Chancellery, The Bruening Cabinets] (Boppard/R.: Boldt, 1990), Vol. 3, Doc. 706.1, 710, 714, 716, 717, 722, 728, 733.1, 739.2

74 Wilhelm's letter is documented by Friedrich Wilhelm von Preussen, Das Haus Hohenzollern 1918-1945 (Muenchen: Langen Mueller, 1985): 203-204; Gerhard Schulz, Staat und NSDAP - Quellen zur Aera Bruening [State and NSDAP - Sources of the Bruening Era], ed. by Gerhard Schulz (Duesseldorf: Droste, 1977), Doc. 68, and Groener's answer, Jonas, Kronprinz, 233
} 
view, it is another incident where it seems obvious that the activities of the Crown Prince were not in support of the Nazi-party. ${ }^{75}$

Pyta/Orth are trying to mitigate this issue, stating that Wilhelm did not write the letter on his own speculating that it was initiated by his friend Kurt von Schleicher. Schleicher, head of the Reichswehr ministry at the time and a schemer for the President behind the scenes, thought that the SA-ban was tactically not a wise decision and needed to be prevented. Pyta/Orth are also speculating further about Schleicher's motives to support the absurd conclusion that canceling the SA-ban was supposed to be a blow to the Nazis. The logic goes as follows: a cancellation of the ban would have forced the NS-leadership to continue paying the SAmembers, and because the NS-party was financially constantly in dire straits, that issue would have worked as a constraint, reducing their window of opportunity to come to power soon. In other words: cancelling the SA-ban would have helped to ruin the Nazi-party that was constantly short of funds, and therefore a clear sign of being in opposition to the NSmovement. Although this is an absurd construction which is completely speculative without any evidence and completely unproven regarding Schleicher's motives, Pyta/Orth using this 'unconventional' conjecture to set the stage for their general thesis that Wilhelm and his circle were not supporters but staunch adversaries in opposition of the Nazi-party. ${ }^{76}$

The reports by Brandt and Malinowski are telling a different story. Brandt points out that the impact of Wilhelm's letter was twofold: on the one hand trying not only to push for the cancellation of the ban but in criticizing Groener Wilhelm was contributing to the overall goal of the 'national opposition' to get rid of the Bruening government, which was already contemplated by Hindenburg and his advisors. On the other hand, arguing against the SA-ban meant to support a paramilitary organization that was mostly responsible for those civil war clashes on the street. The SA was an important tool of the Nazis to threaten the established order with chaos and violence based on the proposition that Hitler was the only 'savior' of law and order, and only he would be able to end the current situation, if Hindenburg would appoint him Chancellor of the Reichsregierung ${ }^{77}$ (Federal Government). Malinowski concurs and adds that Wilhelm's letter was less a critique of the SA-ban then a calculation to put pressure on Hindenburg to dismiss Bruening and Groener who were supported by the social democrats and were not effectively moving to the Right. The actual cancellation of the SA-

\footnotetext{
${ }^{75}$ Clark, Report, 3-4, 7, 10-11

${ }^{76}$ Pytha/Orth, Report, 56-58

${ }^{77}$ Brandt, Report, 40-41
} 
ban during the election campaign of July 1932 caused 300 deaths and 1,100 wounded people that can be mostly traced back to the activities of the SA. ${ }^{78}$

The reports in favor of the Hohenzollern are missing the point that since the critical election of September 1930, where the Nazi-Party reached a significant percentage of the votes for the first time (from $2,4 \%$ in 1928 to $18 \%$ in 1930), a fundamental shift of the political landscape had occurred. In relation to this crucial shift, the Bruening Government struggled with the problem of how to deal with the Nazi movement and its paramilitary organization, the SA, which typically campaigned through violent clashes that ended up with the death of a certain amount of their opponents. It was well understood that the authority of the state and its monopoly of violence was at stake, considering that the NS-party seemed to operate on the brink of legality (or sometimes crossed over to illegality like at the putsch in 1923) and internal reports both at the Reich and the Prussian Ministry of the Interior concluded that Hitler's strategy of 'legality' was just a cover for an illegal takeover of power in the Reich and the Laender (German States). ${ }^{79}$

Although Hitler had pointed out at several occasions, that he was following a 'legal' strategy ${ }^{80}$ (as a witness before the German Reichsgericht ${ }^{81}$ [High Court] in 1930), several times between 1930-33 searches of SA-facilities in Prussia, Hessen, Bavaria and other German States had unearthed documents, that definitively showed plans to implement a putsch in order to seize power. This was conceived in a scenario that their candidate at the President's election would not be elected, that was supposed to start a violent crusade against their former adversaries. ${ }^{82}$ Also, the sign was on the wall, that Hitler's 'legal' strategy to seize power, was not accepted at the regional level of the SA despite the fact that he had issued an internal decree, that labeled these activities as wrong and self-serving if not damaging to the cause and threatened

\footnotetext{
${ }^{78}$ Malinowski, Report, 76-78

79 Der verpaßte Nazi-Stopp, die NSDAP als staats- und republikfeindliche, hochverräterische Verbindung; Preußische Denkschrift von 1930 [The missed Nazi stop, the NSDAP as a hostile anti-state and anti-republic, treasonable Association; Prussian memorandum from 1930], ed. Robert M. W. Kempner (Frankfurt/M. 1983); the diverse reports about the danger of the Nazi-party by the Reichsinnenministerium (Interior Ministery) and the Prussian Innenministerium, Schulz, Staat und NSDAP, Doc. 6, 7, 12, 13, 44, 59a, 59b

${ }^{80}$ Regarding Hitler's strategy of legality, Roy J. Hulbert, Hitler's Idea of a 'Legal Revolution' and the Triumph of Nazism, A study of Politics and Moral Anarchy (Ph. D. Diss., University of Washington, 1975)

${ }^{81}$ See Hitlers Statement as a witness at the Reichsgericht and the problem of legality, in: Akten der Reichskanzlei, Kabinett Bruening [Files of the Reichskanzlei, Bruening Administration], Vol. 1, Doc. 118.2, 163.1.-2., 206.1; Hulbert, Legal Revolution, 68-135, Hitlers statement at the trial, 79-96; Vogelsang, Reichswehr, 90-93; Guido Enderis, "Hitler would scrap Versailles Treaty and use Guillotine," in: New York Times, September 26, 1930

82 The Boxheim Documents and the reaction, in: Akten der Reichskanzlei, Kabinett Bruening, Vol. 3, Doc. 572, 574; Hulbert, Legal Revolution, 185-230, Vogelsang, Reichswehr, 145-147; Schulz, Staat und NSDAP, Doc. 58, 60
} 
to exclude everybody from the NS-party who participated in conspiracy cases like the Boxheim documents in the State of Hessen. ${ }^{83}$ SA-members seemed discontent with Hitler's 'legal' strategy and were tired of just playing the part of the Rollkommando, that had to do the dirty work against the political opponents.

At the same time, the Bruening Government developed a plan (or better had the idea) for integrating the Nazi-party into the state, anticipating that at some point in time the participation of the NS-Movement at the Reich government level might be unavoidable, a process aiming at the paramilitary activities of the Nazis hoping that they would drop violence and murder and become 'civilized'. The first contacts between Hitler, Hindenburg and Bruening were initiated in October $1931^{84}$ when the right-wing 'national opposition' tried to unite in the town of Bad Harzburg against the Young-Plan. The NS-party leadership was convinced that at the next election they would easily pass the $50 \%$ mark, envisioning to seize power in the spring of $1932^{85}$, which made them immune to any compromise position with the National Conservatives that were present. In addition, since October 1931, Hitler and the Nazi-party had all the reason to believe that they were taken seriously by the Bruening Government who had made the decision to encourage the "recognition and legalization of the Nazis" $"$ (comparing them to the Social Democrats during the Kaiserreich in the 1880s).

The first test came, when Bruening realized that he needed a two-third majority in the Reichstag including the votes of the 'national opposition' (mostly DNVP and NSDAP) for a special ballot to increase the term of the President instead of exposing him to the risk of another election where the outcome was questionable. In the beginning Groener had a very favorable impression of Hitler and was so smitten by his personality that he later admitted his positive impressions at a meeting of Reichswehr commanders. He advised that Hitler's motives and goals were good intentioned but - in Groener's mind - Hitler was a 'glowing utopist', a 'multitalented' politician that needed support and guidance by more experienced colleagues. In addition, Groener pointed out that he believed the Government needed to "let justice prevail and only fight the extremes, but not the movement as such" and that he would

\footnotetext{
${ }^{83}$ Schulz, Staat und NSDAP, Doc. 47, 258-259; Robert H. Frank, Hitler and the National Socialist Coalition, 1924-1932 (Ph. D. diss., Johns Hopkins University, 1969), 532-541

${ }^{84}$ Huerter, Groener, 307-314; Bruening, Memoiren, 460-473, 461

${ }^{85}$ Hulbert, Legal revolution, 185-186

${ }^{86}$ Huerter, Groener, 316; Bruening, Memoiren, 500-516; Dorothea Groener-Geyer, General Groener, Soldat und Staatsmann (Frankfurt/M.: Societaets-Verlag, 1955): 281-322, Vogelsang, Reichswehr, 135-202
} 
support "all legal aspirations of Hitler", but not those of the troublemakers, the SA, that the Fuehrer needed to bring under control. ${ }^{87}$

After the negotiations with the 'national opposition' failed, the disappointment was big and Groener slowly changed his tune. He now believed that the 'unreliability' of the statements made by the 'national opposition', who had only their own interests in mind, must lead to a renewed focus that the conservatives needed to support Hindenburg for President. They realized that they had to do everything possible to prevent the Nazi-Party from coming to power on their own, in any of the states or at the Reich level. Now Groener looked at Hitler's 'Idealism ${ }^{98}$ negatively and called him a "visionary and an idol of stupidity", who was just a "verbose bogey for the masses". Although he still believed in a modus vivendi with the Nazis blaming mainly Hugenberg ("the poison mixer Hugendubel" ${ }^{89}$ ) for the failure of agreement about the extension of Hindenburg's term. Regarding the possible danger of a Nazi-putsch he figured that Hitler and the NS-leadership knew very well where its limits were, because a violent takeover attempt

"would result in the ruthless use of the power of the state. Hammerstein is the man who strikes brutally, quite unlike Seeckt in 1923/24. The Reichswehr is in our hands which won't fail in this case. ${ }^{, 90}$

But even after the disappointment of a failure to negotiate with the 'national opposition' the politics of the velvet gloves towards the Nazis did not stop. There were several examples that the SA was responsible for a policy of constant provocation and violence that led to numerous death that even Groener called a "murder plague" and a "cultural shame for Germany". 91 Initially, he tried to blame communist organizations causing heavy protest by the Ministers of the Interior of states like Bavaria, Prussia and Baden, who already wanted to ban the SA in

\footnotetext{
${ }^{87}$ Huerter, Groener, 322-323; Schulz, Staat und NSDAP, Doc. 52b

${ }^{88}$ Huerter, Groener, reports that Groener characterizes Hitler in a letter to a friend, 324: "He avoids factual conversations and immediately fantasizes through all centuries of history. He talks like in a trance state with a world-lost look, then he starts with a cascade of words, phrases and pictures, without a comma or period, until he has completely exhausted himself. Impossible to interrupt him and return to this planet. One is exhausted from listening..."

${ }^{89}$ All quotes from, Huerter, Groener, 324

${ }^{90}$ Huerter, Groener, 324; Schulz, Staat und NSDAP, Doc. 54

${ }^{91}$ Huerter, Groener, 316
} 
1931.92 They knew that the violence was mostly caused by the Nazis ${ }^{93}$, and if this organization would be illegal, they considered the main problem solved.

Groener and Schleicher had additional reasons to treat the NS-movement with leniency and respect. On the one hand, they planned to eliminate the paramilitary organizations by consolidating its members in a national Wehrorganisation (military organization) and on the other hand they perceived the members of the paramilitary organizations as a potential reservoir for future Reichswehr divisions. The national Wehrorganisation was supposed to be under the tutelage of a Reichswehr general and they hoped (from a foreign policy perspective) through this consolidation they could put pressure on the Allies to loosen up the requirements of the Versailles Treaty, also intending that this new type of 'militia' organization could break through the 100,000 soldier ceiling that was imposed on Germany. Furthermore, from this perspective, the Reichswehr leadership hoped to solve the problem of their own planning and projections as they estimated not having enough recruits for their projected army of 21-36 divisions $(570,000 \mathrm{men})$ in the future ${ }^{94}$, that could be applied as a leverage or used for a war against the 'dictate' of the Versailles order, when Germany would be strong enough in the future.

Therefore, they welcomed the education that people had received in paramilitary organizations like the SA and considered it valuable for future Reichswehr divisions. ${ }^{95}$ The thinking behind all these activities was not only the doctrine of the Primat der Aussenpolitik but the idea of a necessary 'militarization' of the populace, promoting "military values like obedience, discipline and self-sacrifice"96 that would be crucial for the next conflict with France and Great Britain but was colliding with the democratic values of the republic and its official policy of 'peaceful change'. They believed that violence should only be directed against foreign countries, in this case against the 'winners' of the Versailles order, that allegedly held Germany back from regaining its great power status. The representatives of the Reichsrat (Council of the German States) had demanded the long-awaited ban of the SA and threatened - in case Groener would continue his course of appeasing the Nazi-party - to act

\footnotetext{
${ }^{92}$ See the protocol of their conference on November 17, 1931, Schulz, Staat und NSDAP, Doc. 41b

${ }^{93}$ Huerter, Groener, 349

94 Wilhelm Deist, "Zum Problem der deutschen Aufruestung" [The Problem of German Rearmament], in: Francia 5, no. 4 (1977): 539-565, 546-547

95 Deist, "Zum Problem”, Francia, 547; Michael Geyer, "Das Zweite Ruestungsprogramm (1930-1934)" [The second Armaments Program], in: Militaergeschichtliche Mitteilungen 17 (1977): 125-175

${ }^{96}$ Matthew N. Buchholtz, The ideological motivations of General Kurt v. Schleicher, the Nazi Movement, and the Collapse of the Weimar Republic, 1930-1933 (M. A. Thesis, University of Alberta, 2007): 65-81
} 
by themselves ${ }^{97}$. If States like Prussia, Bavaria, Wuerttemberg, Baden and Hessen would take independent action, it became a big problem for the administration and the Reichswehr, who suddenly had to face a counterweight besides the Reichstag, whose power could not be matched with emergency decrees by the President.

Groener realized that he had no choice but preempting the potential actions of the Laender with his own measures and he believed that a ban of the SA via emergency decree was compatible with his strategy of integration and his plan to consolidate all military organizations in a state sponsored central 'militia' organization. ${ }^{98}$ On April 13, 1932 the President finally signed an emergency decree that banned the NS paramilitary organizations SA and SS. The public reaction to the decree was predictable, while the republican press and political parties from SPD to DVP welcomed this decision and called it overdue, but the 'national opposition' was furious.

\section{The Crown Prince letter to Hitler on Sept. 25, 1932}

On September 25, 1932, the Crown Prince sent a letter to Hitler asking him to give up his fundamental opposition against the Papen-administration and accept their offer to become a member as Vice-Chancellor of the cabinet. He was worried that Hitler's refusal would be counterproductive in the long run playing into the hands of those, who were the declared enemies of the 'national opposition'. Wilhelm is suggesting again that Hitler's "wonderful movement" needs to come out of the "unproductive opposition" and he could still fight against the Papen Government but should at least support the "national demands of equality and the right of rearmament" regarding foreign policy. This would have a "tremendous impact" on foreign countries considering as well as on the majority of people in Germany who would like to put their "fatherland" first and it would demonstrate the necessary unity, National Conservatives considered crucial for regaining the great power status. ${ }^{99}$

While Pyta/Orth are completely silent on this issue, Clark is interpreting Wilhelm's letter to Hitler less as an act of "support and sympathy" for the Nazi Party but as a request to be open for compromise and a suggestion to enter the Papen administration as a Vice-Chancellor to

\footnotetext{
${ }^{97}$ Schulz, NSDAP und Staat, Doc. 26, 41a, 41b, 36, 42, 61, 63

${ }^{98}$ Huerter, Groener, 336-340; Schulz, Staat und NSDAP, Doc. 65, 66, 67, regarding the sequence of events, Doc. 71

${ }^{99}$ Wilhelm's letter to Hitler, F. W. von Preussen, Hohenzollern, 103-104, and Hitler's answer, 105-108
} 
unify the Right against the republic. Clark sees the Crown Prince' letter as a typical expression of the concept of 'taming' to integrate the Nazi-party into the Government, which was pursued by a large part of the "nationalistic and reactionary Right". In Clark's mind, the 'taming concept' seems to work as a legitimate excuse to do business with the Nazis and a justification for Wilhelm's letter to Hitler. But Hitler's answer demonstrates not only the intransigence of his 'either the whole power or nothing' concept but is also, according to Clark, further evidence of the illusion of the 'taming' strategy and that Hitler, refusing the advice of the Crown Prince, did not profit from Wilhelm's counsel by any means. ${ }^{100}$

Brandt is quoting in his report from the letter extensively and points out that Wilhelm specifically had the unity between the different factions of the 'national opposition' in mind. Thereby, the Crown Prince demonstrated - despite the continued murders of the $\mathrm{SA}^{101}$ - no distance to the Nazi-party. Malinowski also indicates that the Crown Prince in several letters to Schleicher and Hindenburg advocates that 'communist troublemakers' should be eliminated 'without mercy' and rejects the idea of behaving modest and respectable. ${ }^{102}$ Malinowski also points out that this needs to be specifically examined considering that Wilhelm's letter to Hitler was sent just one months after the Potempa-murders by SA members in Gleiwitz/Silesia. ${ }^{103}$ Hitler had sent a solidarity note declaring that the perpetrator's freedom from prosecution (as a special court had sentenced them to death) was a question of honor for the whole movement. ${ }^{104}$ While Clark is trying to downplay the letter to Hitler without providing any historical context, Brandt and Malinowski are both showing with whom the Crown Prince is trying to form an alliance: a political movement that does not shy away from violence and murder.

In Clark's view, Wilhelm did not support the Nazi-Party by advising Hitler because the Fuehrer refused this outright. In short, Hitler did not follow Wilhelm's advice and that is the reason why there was no support to begin with. Clark's strategy is obvious: whatever the Crown Prince has done, it is his 'opinion' that this will not amount to a support of Nazism. With the 'taming concept' in mind Clark is not only using it as an excuse for Wilhelm's

\footnotetext{
${ }^{100}$ Clark, Report, 4, 7, 11

${ }^{101}$ Brandt, Report, 20, 41-43

102 Malinowski, Report, 20-22

${ }^{103}$ Malinowski, Report, 21

104 See the documentation including the judgement by the local court, Kurt Kluke, "Der Fall Potempa" [The Potempa Case], Vierteljahrshefte fuer Zeitgeschichte 5, no. 2 (1957): 279-297; Richard Bessel, "The Potempa Murder", Central European History, 10, no. 2 (1977): 241-254, Hulbert, Legal Revolution, 280-324
} 
activities, but he wants to suggest a general division or rift between the National Conservatives and the Nazis without addressing any details or the identity of the goals of the 'national opposition'.

Now, after there has been an international discussion and those Gutachten for the Hohenzollern (including Clark's) have been published and widely critized, Clark is suddenly making amends and is now stating that - "in light auf newly discovered sources" - that "Wilhelm did not want to tame Hitler." 105 Surprisingly - for the first time - Clark seems to give in to the overwhelming evidence presented by Brandt and Malinowski and is now trying to mitigate the damage his 'appraisal' has caused, although without taking back his old judgement that the Crown Prince has not 'significantly advanced' National Socialism. What he calls 'newly discovered sources' were already available in 2011, admitting - kind of sheepishly - that he did not expect "such a controversy"106 with all the other historians and is pleading jointly for a 'concerted effort' of the historical community to work together and do not turn this in to a dispute between them. Clark's admissions are not only half-hearted and tacit - suddenly bashing Wilhelm now for his anti-democratic stance - admitting what has been known for a long time. His 'expert opinion' is not only suffering from a lack of information but his conclusions do not even match the meager facts he has provided.

The important question to be addressed here is why there was a 'taming concept' in the first place. It only makes sense - from the perspectives of the National Conservatives - if there was something worth 'taming' that could be applied to a target with whom there was a general agreement about the same goals and interests. Otherwise, there would be no 'taming' concept, but more like a strategy of conflict and disagreement. The 'taming concept' - if there ever was one worthy of this term - was conceived to bring in the Nazis, who were opposed to the political system at the time and were determined to abolish it. The 'taming concept only made sense, if there were common goals with the NS-movement the Nazis and a general agreement about abolishing the democratic system. Otherwise the Nazis would have been treated like communists that were bent on overturning the constitution to establish a kind of dictatorship the National Conservatives found undesirable and wanted to avoid at any cost. ${ }^{107}$

\footnotetext{
105 Andreas Kilb, "Wilhelm wollte Hitler nicht zaehmen", Interview with Christopher Clark, in: FAZ.net, November 4, 2020

${ }^{106}$ Kilb, "Wilhelm wollte Hitler nicht zaehmen", FAZ.net, November 4, 2020

107 Klaus-Juergen Mueller, "Nationalkonservative Eliten zwischen Kooperation und Widerstand"[National Conservative Elites between Cooperation and Resistance], in: Der Widerstand gegen den Nationalsozialismus.
} 
Therefore, it would be more adequate not to call the actual concept 'taming', but rather 'integrating' or a concept of 'cooperation' or an 'alliance', which would be closer to the actual events. The term in German typically used at the time was heranziehen or heranfuehren which means to 'draw in' or to 'enlist'. This included that National Socialism was to become a part of the government that National Conservatives wanted to harness for several reasons: on the one hand to use the popular following of the Nazis to integrate them into the state to shake off the 'radical' elements being assembled in the SA, and on the other hand to use those people with a para-miliatery education as a reservoir for the Reichswehr in the future. The most important goal for both partners of the alliance was the elimination of those dissenters at home that stood in the way of rearmament, to recover those territories 'lost' in 1919 (and potentially more with or without war) ${ }^{108}$, that Hitler and the Nazis had in mind that the National Conservatives would support when the time had come. When they formed a coalition in January 1933, Papen had called their alliance 'framing' instead of 'taming', a term, that reflected their role more appropriately.

But to use the term 'taming' sounded better for several reasons: on the one hand it implies that there was a conflict with a partner that was tamed or needed 'taming', and on the other hand it is suggesting that the National Conservatives who helped Hitler and agreed to the enabling act did this out of 'noble' and 'good' intentions. The National Conservatives intentions could not be more clear on or before January 30, 1933: they wanted and authoritatrian solution to dissolve the republic and did not consider the 'other half' of Germany that did not vote for the 'new' coalition on March 5. In fact, they looked the other way or even welcmoned it, when the Nazis put Social Democrats and Communists in concentration camps or simply killed them as the supporters of the revolution of 1918. The other half of Germany was excluded in 1933 while National Conservatives felt they were a part of Hitlers 'new' government and the 'national uprising' as they used to call it. Afterwards, in 1945 when the whole experiment fell apart, everybody downplayed its engagement and claimed they did not know what they were getting into. The crucial point - as the example of the Crown Prince tells us - was that the

Die deutsche Gesellschaft und der Widerstand gegen Hitler, ed. Jürgen Schmädeke and Peter Steinbach (Muenchen: Piper, 1986): 24-49

${ }^{108}$ Hugh Trevor Roper, "Hitler's Kriegsziele”[Hitler's War Aims], Vierteljahrshefte für Zeitgeschichte 8, no. 1 (1960): 121-133; Hugh Trevor Roper, "Hitler's War Aims, in: Aspects of the Third Reich, ed. H. W. Koch (Basingstoke: Macmillan, 1985): 235-250; David Aigner, "Hitler's ultimate Aims - a Program of World Domination?", in: Koch, Aspects, 251-266; Eberhard Jaeckel, Hitlers Weltanschauung [Hitler's Ideology] (Stuttgart: DVA, 1991, $4^{\text {th }}$ print.); Frederick T. Birchall, "Reich is thinking of War despite its Talk of Peace", in: New York Times, October 8, 1933; Axel Kuhn, Hitlers aussenpolitisches Programm [Hitler's Foreign Policy Program] (Stuttgart: Klett, 1970): 11-140 
National Conservatives actively supported and wanted the Nazis to succeed in getting rid of the hated republic. To them - without a doubt - anything would have been better than the Weimar democracy.

The consequences of a seizure of power by the Nazis before 1933 were widely discussed and numerous documents and events tell us about the warnings ${ }^{109}$ of what might happen if Hitler and his brethren would have access to the levers of power. To be sure, the Nazis were publicly very frank about their policies in case they would ascend to highest level of Government, and what they would do admitting openly against whom their actions would be directed:

"A National Socialist emergency decree would have had a completely different impact here: in the negative, through the immediate arrest and conviction of all communist and socialdemocratic party officials, and the concentrated elimination of the murderous districts and sending the intellectual instigators to concentration camps. On the positive side through the reorganization of the national educational system, which was destroyed by the November revolt of the previous usurpers of governmental authority in 1918." 110

This promise contains everything that six months later became reality: the exclusion and elimination of all political adversaries, committing all 'suspicious' characters to newly established concentration camps (the special invention for arbitrary and violent abuse independent from the 'normal' prisons) and a new way of education to manipulate the masses in the interest of the new regime. Not only is this prediction cited above a correct description of what happened after January 1933, it is also noteworthy whom the Nazis are planning to leave out, basically all parties to the right of the social democrats which included not only all 'nationally minded' but also those that were not associated with the Left specifically those conservatives transferring power to the Nazis. It it basically untrue when members of the National Conservatives later complained that they were unaware what the Nazis represented, while they were only disagreeing with them on 'methods' but not on the goals they both shared.

The letter from the Crown Prince to Hitler in September 1932, is not an expression of a 'taming concept' but part of a strategy of cooperation and basic agreement that was supposed to remind the Fuehrer to stick to the common goals. The Crown Prince was not worried about

\footnotetext{
109 Bodo Scheurig, Ewald von Kleist-Schmenzin, ein Konservativer gegen Hitler [A Conservative against Hitler] (Oldenburg: Stalling, 1968): 105-126; his contemporary memo about the NS-movement, Doc. II, "Der Nationalsozialismus - eine Gefahr“ [National Socialism - a Danger], 255-264

${ }^{110}$ Quote from the Nazi-Press organ 'Voelkischer Beobachter', August 11, 1932, in: Kluke, Potempa, 281-282
} 
any 'taming', he was rather concerned that Hitler might have passed up an opportunity that a united Right could legitimately take over the reins of the Federal Government as a special chance that might not come back again soon.

\section{The Hohenzollern, the 'Day of Potsdam' and the 'Enabling Act'}

The next stage in the Nazi seizure of power (after Hitler was appointed Chancellor by Hindenburg on January 30, 1933 ${ }^{111}$ ) was attacking the problem that in the last three years before there was - due to the success of the Nazis at the voting booth - no effective governing majority of the 'Weimar party coalitions' and the Chancler could politically only survive with the help of Presidential decrees, that replaced the votes of Parliament. In appointing him, Hitler had promised Hindenburg that only he could find a way out of the vicious cycle of 1932 that was riddled with emergency orders, parliamentary dissent, dissolution of the Reichstag and new elections every six months. There was no party coalition anymore, that was based on the majority of votes and the emergency decrees of the President had replaced the 'normal' form of governing. The cure for this 'disease' was supposed to be the passing of an 'enabling act' (Ermaechtigungsgesetz) ${ }^{112}$ that was designed to deliver a majority for a foreseeable time in voting for an 'enabling act' - that would transfer the legislative powers of Parliament to the Government and become itself superflous. Hindenburg hoped in appointing Hitler and a cabinet of 'national concentration' to make a first move towards the envisioned unity that was called Volksgemeinschaft (people's community) and supposed to replace the dissenting factions of Parliament and overcome all conflicts and disagreements (the way it happened in August 1914) putting an end to the pluralist system of democracy that was

\footnotetext{
${ }^{111}$ Akten der Reichskanzlei, die Regierung Hitler [Files of the Reichskanzlei, the Hitler Government, hereinafter cited as 'AdR Hitler'], Teil I [Part I]: 1933-34, 2 Vol., edited by Karl-Heinz Minuth (Boppard: Harald Boldt Verlag, 1983)

112 The details of the enabling law, Irene Strenge, "Das Ermaechtigungsgesetz vom 24. Maerz 1933" [The Enabling Law of March 24, 1933], in: Journal der juristischen Zeitgeschichte 7, no. 1 (2013): 1-46; regarding the term 'Machtergreifung' (seizure of power), Gottfried Jasper, Die gescheiterte Zaehmung. Wege zur Machtergreifung Hitlers, 1930-1934 [The failed Taming, Different Paths to Hitler's Seizure of Power, 1930-34] (Frankfurt/M.: Suhrkamp, 1986): 14-15 is pointing out that the term Machtuebernahme (takeover of power) or Machtauslieferung (delivery of power) would be more accurate; author prefers the term Machtuebergabe (transfer of power) that is adequate because it correctly summarizes what initially happened; the term Machtergreifung (seizure of power) would fit better the events after January 30, 1933 until the Sunmer of 1934, when Hitler made himself the successor of Hindenburg and eliminated the 'threat' of the SA; for a detailed discussion of these terms, Norbert Frei, "Machtergreifung', Anmerkungen zu einem historischen Begriff'[Seizure of Power, Remarks about a historical Term], Vierteljahrshefte für Zeitgeschichte 31, no. 1 (1983): 136-145
} 
perceived as too factious and a failed experiment. ${ }^{113}$ To achieve this goal it seemed necessary to create an idealized symbol of unity between the established National Conservative elites and the Nazi-movement ${ }^{114}$, a symbol of unity for the future represented through the ceremonies by the 'Day of Potsdam' on March 21, 1933, where the old and the new were supposed to merge and show the 'new' Germany (as a rehearsal of the enabling act), although the other half of the country was not represented.

In his report Clark is trying to downplay the significance of the whole event and the appearance of the Crown Prince as he has done so with all the other 'incidents', in which Wilhelm has supported the Nazis. Clark is describing Wilhelm's role as minor, because the Crown Prince personally had no 'official' invitation, speculating that Wilhelm probably attended only out of jealousy because of the appearance of his brothers August Wilhelm, Eitel and Oskar, also following Hitler's promise to restore the monarchy. Therefore - according to Clark - the Crown Prince had reasonable and legitimate motives to show up and the fact that Wilhelm attended the festivities he considers negligible because Hindenburg and Hitler were the focus of attention, while Wilhelm was - according to his role in numerous press reports barely mentioned on the side. ${ }^{115}$

Pyta/Orth are downplaying his attendance even further, denying the sequence of events on the day of the ceremony on March 21, 1933. Although confirmed by several contemporary witnesses who attended the event, Pyta/Orth squabble over details to confuse the reader. In their view, the unconfirmed seating arrangements, the lack of photos of the Crown Prince and Hitler is supposed to demonstrate Wilhelm's 'inconspicuous' role and that the Nazis did not attach any importance to his attendance. They prefer the interpretation of the German historian Martin Sabrow, whom they are quoting extensively. Sabrow asserts - without any evidence - that at the ceremony in Potsdam the National Conservatives did not 'capitulate' vis-à-vis the Nazis, that the event was rather a symbol of the competition between the two groups and that National Conservatives emerged as the winner of the 'Day of Potsdam' on March 21, 1933. ${ }^{116}$ Thereby, Pyta/Orth are trying to picture the event, not as a sign of

\footnotetext{
${ }^{113}$ Pyta, Hindenburg, 820-823

${ }^{114}$ Regarding the alliance of the elites, Martin Broszat, "Der Zweite Weltkrieg: ein Krieg der alten Eliten, der Nationalsozialisten oder der Krieg Hitlers?'[The Second World War, a War of the old Elites, of National Socialism or the War of Hitler?], in: Die deutschen Eliten und der 2. Weltkrieg, ed. Martin Broszat, Klaus Schwabe (Muenchen: C. H. Beck, 1989): 25-71

${ }^{115}$ Clark, Report, 4-5, 7-8, 11-12

116 Pyta/Orth, Report, 83; to corroborate their position Pyta/Orth are quoting several publications of Martin Sabrow, "Der doppelte Mythos"[The double Myths], in: Potsdamer Neueste Nachrichten, March 21, 2013;
} 
cooperation but as a power struggle of competition and confrontation, following the old German saying was nicht sein kann, dass nicht sein darf ("what cannot be that must not be'). ${ }^{117}$

Brandt and Malinowski both view the 'Day of Potsdam' as the central event, where part of the 'nationally' minded Right demonstrated reconciliation and cooperation with the NSmovement that was essential for the passing of the enabling act in the Reichstag two days later. Brandt is pointing out that there are several photos where Wilhelm is shown in a conversation with Hitler, Hindenburg and Mackensen and that it is also well-known that Hitler personally visited the Crown Prince the day before in Caecilienhof to invite him to the festivities in Potsdam hinting towards his mantra about the restoration of the monarchy. ${ }^{118}$ "In order for the arrangement to work effectively, National Conservatives had to participate to testify to the respectability of the new rulers from the ranks of the NSDAP, which was especially true for the Crown Prince right after President Hindenburg (...)." ${ }^{\text {"119 }}$ Malinowski is adding that even after 1945 Wilhelm has admitted that he was impressed by Hitler's Potsdam speech that he called 'historical' and added that he had rarely experienced a speech that dealt so 'thoughtfully' with German history. ${ }^{120}$

Contrary to the claims of the reports in favor of the Hohenzollern, the event on March 21, 1933 was a day of cooperation and unity between the National Conservatives and the Nazis, as several contemporary sources have shown in contradiction to the assertions of Sabrow and Pyta/Orth. ${ }^{121}$ An additional point could be made in poiting ouit, that the Nazis needed the National Conservatives more than the other way around and used the display of unity as a projection for the political dealings in the future, that was based on false promises, because Hitler had no use for 'partners', because he wanted the services of the National Conservatives

Martin Sabrow, "Der 'Tag von Potsdam', Zur doppelten Karriere eines politischen Mythos" [The Day of Potsdam, the double Advancement of a Myth], in: Der Tag von Potsdam, der 21. Marz 1933 und die Errichtung der nationalsozialistischen Diktatur, ed. Christoph Kopke and Werner Treß (Berlin: Walter de Gruyter, 2013): 47-86, 75

${ }^{117}$ Pyta/Orth, Report, 78-90

118 Brandt, Report, 23-24, 50-51; regarding Hitler's invitation, Martin Goertemaker, "Das Ende Preussens, $1933-$ 1947”, in: Preussen, Geschichte eines Mythos, ed. Julius Schoeps (Berlin: Weltbild, 2001): 198-219, 200

119 Brandt, Report, 51

${ }^{120}$ Malinowski, Report, 42

${ }^{121}$ Hans Wendt, Die Nationalversammlung von Potsdam, Deutschlands grosse Tage 21. Bis 23. Maerz 1933 [The National Assembly of Potsdam, Germany's Great Experience, March 21-23, 1933] (Berlin: Mittler, 1933); Hans Hupfeld, Reichstags-Eroeffnungsfeier in Potsdam, das Erlebnis des 21. Maerz in Wort und Bild [The opening Celebration of the Reichstag in Potsdam, the Experience of March 21, 1933 in Text and Pictures] (Potsdam: Hayn, 1933) 
only as subordinates. Two days later, the political reality at the Reichstag meeting, where the enabling act was passed, did not leave any doubt to a thoughtful observer who was in charge at the time and would be in the future. ${ }^{122}$ For the Nazis, the goal was deluding the public and getting support for the 'national uprising' and the 'spirit' of Potsdam, mostly hiding their real intentions for suppressing all others and for war and conquest in the future. ${ }^{123}$ Both parties at the festivities wanted to be part of the 'new' Germany, confirming the symbolic 'marriage' at the event ${ }^{124}$, as they shared important goals in domestic politics and foreihn policy. Hitler and Goebbels (who became the new Minister of Propaganda a week before ${ }^{125}$ ), who were most interested in the deception, cleverly determined that the passing of the 'enabling act' needed a special ceremony before hand to minimize the potential impact and make it more digestible for those conservatives, who had doubts about the Nazis. ${ }^{126}$ A "propaganda extravaganza of the first order"127, a special holiday, an event of pomp and circumstance that would emphasize the new 'national revolution', as a symbol of the "national uprising"128, to accentuate and 'honor' the alliance with the National Conservatives ${ }^{129}$, from whom they had received its powers almost two months ago. The Nazis knew very well, to whom they still had to cater to

122 See the documentation by Klaus Scheel, Der Tag von Potsdam [The Day of Potsdam] (Berlin: Brandenburgisches Verlagshaus, 1996); Jesko von Hoegen, Der Held von Tannenberg, Genese und Funktion des Hindenburg Mythos [The Hero of Tannenberg, Genesis and Function of the Hindenburg Myth] (Koeln: Boehlau, 2007): 383-405, who is also pointing towards Hitler's early plans for a state act of this magnitude in combination with his 'legal' strategy reported by the former SA-man Kurt Ludecke, I knew Hitler (London: Jarrods, 1938): 413; regarding Ludecke's credibility, Roland V. Layton, "Kurt Ludecke and I knew Hitler: an Evaluation", Contemporary History 12, no. 4 (1979) 372-386

${ }^{123}$ Guido Enderis, "Potsdam spirit hailed, Hindenburg invokes its return as Deputies meet in Old Church, Honor Ex-Crown Prince”, New York Times, March 22, 1933: 1; “Hitler's Speech at Potsdam”, New York Times, March 22, 1933: 8

${ }^{124}$ As a contemporary Hindenburg biographer had in mind, Gerhard Schultze-Pfaelzer, Hindenburg und Hitler zur Fuehrung vereint [Hindenburg and Hitler united to lead] (Berlin: Stollberg, 1933): 81-96; Gerhard SchultzePfaelzer, Hindenburg - ein Leben fuer Deutschland [Hindenburg - a life for Germany] (Berlin: Ullstein 1934)

125 AdR Hitler, Vol. 1, Doc. 46, Denkschrift ueber die Errichtung eines Reichskommissariats fuer Volksaufklaerung und Propaganda [Memorandum on the establishment of a Reich Commissioner for the Enlightenment of the People and Propaganda] March 7, 1933, 168-171

${ }^{126}$ Regarding the role of Goebbels, Hoegen, Held von Tannenberg, 384-386

${ }^{127}$ Hulbert, Legal Revolution, 333

${ }^{128}$ Hulbert, Legal Revolution, 343; Bracher, Machtergreifung, 152, points out that the day of 'national uprising' should be rather called the 'day of national oppression' because the other half of the people was not represented at the Potsdam festivities; Hans Mommsen, "Die deutschen Eliten und der Mythos des nationalen Aufbruchs von 1933" [The German Elites and the Myth of National Uprising in 1933], in: Merkur 38, no. 423 (1984): 97-102; Jasper, Zaehmung, 172-175

${ }^{129}$ AdR Hitler, Vol. 1, Doc. 44, Ministerbesprechung vom 7. Maerz 1933 [Ministerial meeting, March 7, 1933], $159-166,159-160$ 
and nurture the illusion, that this was still an equal 'partnership' ${ }^{130}$ and a matter of real power sharing.

The whole nation was to be a part of the festivities while the entire ceremony was broadcast throughout the Reich. ${ }^{131}$ The event was designed as the reopening of the new Reichstag featuring its members (KPD and SPD members chose not to attend), the upper level of the bureaucracy, the cabinet, important military officers, Hitler, Hindenburg and members of the Royal family including the Crown Prince. The other half of Germany, represented by social democrats and communists was conspicuously absent and only those were present who represented the 'nationally' minded Germany, that had bet on the NS-movement. The reason for the "Ruehrkomoedie"132 (emotionally charged comedy) in Potsdam's Garrison Church was obvious: a combination of a special opening of the new Reichstag ${ }^{133}$ and a confirmation of the marriage of the traditional Prussia of the past with the Nazi-movement at a location that was originally used for the inauguration of the first German Reichstag on March 21, 1871 after the founding of the 2 . Reich presided by Bismarck. It also contained the corpses of the important Prussian kings that were crucial for upholding the traditions that went back more than three hundred years. This was a 'show' of unity, a "theatre coup" ${ }^{134}$ staged by the Nazis ${ }^{135}$, although envisioned and wanted by Hindenburg ${ }^{136}$ in cooperation with their conservative colleagues in the administration that was - in Goebbels words - part of the process of Gleichschaltung ${ }^{137}$

\footnotetext{
${ }^{130}$ See the depiction of the event, Pyta, Hindenburg, 820-826, where he is emphasizing the unity and deepening of the relationship between Hindenburg and Hitler, without mentioning his later thesis of a potential power struggle or competition between National Conservatives and Hitler

${ }^{131}$ Hoegen, Held von Tannenberg, 384-386

${ }^{132}$ Friedrich Meinecke, Die deutsche Katastrophe, Betrachtungen und Erinnerungen [The German Catastrophe, Reflections and Memories] (Zuerich: Aero, 1946): 25

133 This is reflected by a special feature as a commemoration of the opening session of the Reichstag at the Garrison Church in Potsdam on March 21, 1933, a 'state act' to be remembered, "Der Staatsakt in Potsdam, Blaetter der Erinnerung an die feierliche Eroeffnung des Reichstags am 21. Maerz 1933" featuring a summary of the event with the speeches of Hindenburg and Hitler (and Goering's as the President of the Reichstag at the Krolloper in Berlin later that afternoon) in a special typeset without the usual columns, Verhandlungen des Reichstags, 8. Wahlperiode, Vol. 457 (Berlin, 1934): 1-14
}

${ }^{134}$ Bracher, Machtergreifung, 144

${ }^{135}$ Guido Enderis, "Nazis order Reich to celebrate Unity”, New York Times, March 19, 1933, 1; "Planes to patrol Reich Celebration", New York Times, March 20, 1920, 5

${ }^{136}$ AdR Hitler, Vol. 1, Doc. 43, Vermerk Meissners ueber eine Besprechung zur Gestaltung der Eroeffnungsfeier des Reichstages, 7. 3. 1933 [Meissner's note about a discussion on the organization of the opening ceremony of the Reichstag, March 7, 1933], 157-158

137 Karl-Dietrich Bracher, "Stufen totalitärer Gleichschaltung: Die Befestigung der nationalsozialistischen Herrschaft 1933/34"'[Levels of totalitarian conformity: The consolidation of the National Socialist rule 1933/34], Vierteljahrshefte für Zeitgeschichte 4, no. 1 (1956): 30-42; the Gleichschaltung was meant to be a centralization of all political power in Berlin and specifically eliminate the power in the Southern German States, which were 
(equalization of powers) between the revolutionary Government and the people". ${ }^{138}$ Both partners had committed to this and wanted to implement the opening of the Reichstag and the passing of the 'enabling law' that the New York Times back then called the 'Dictatorship' Act. ${ }^{139}$

A good example of this is the role of the catholic Zentrum ('Center' ${ }^{140}$ ) party, who wanted to believe Hitler that abolishing all basic rights would only apply to the communists and the social democrats and not to them. As a result, they gave away whatever leverage they may have had, considering that Hitler and the Nazis needed the votes of the Zentrum knowing that it would look better (to the German People as well as to the world) if the two-thirds majority came from the support of all the conservative parties right of the social democrats and none of them would break ranks and vote against it. ${ }^{141}$ On the other hand, the Nazis had to resort to cooking the books either way to get to the two-thirds majority in the Reichstag. They had to reduce the overall seats of Parliament through canceling the seats of the communists estimating correctly that the social democrats would be the only party who would vote against it. ${ }^{142}$ Without the votes of the 'Center' party they would have had to resort to further manipulation and threats in getting to the required majority, as Hitler in a rare moment of frankness pointed out in his speech:

"(...) we appeal at this hour to the German Reichstag to legalize what we could have taken otherwise. We do it because of the law - not because we overestimate power - and, at the end

more liberal and a cause for constant dissent, AdR Hitler, Doc. 60, Ministerbesprechung vom 15. Maerz 1933 [Ministerial meeting, March 15, 1933], 212-214

${ }^{138}$ Bracher, Machtergreifung, 146

139 “Text of Dictatorship Act”, New York Times, March 24, 1933, 1; "Speech of Hitler in Reichstag on his Policies for Germany", New York Times, March 24, 1933, 2; Guido Enderis, "Hitler is supreme under Enabling Act", New York Times, March 27, 1933, 5; "Hindenburg less active, Hitler to issue decrees with more authority than Predecessors, bars a Monarchy now", New York Times, March 24, 1933, 1; Harold Callender, "The German Mind in a Ferment", New York Times, April 30, 1933, SM 1

140 AdR Hitler, Vol. 1, Doc. 68, Ministerbesprechung vom 20. Maerz 1933 [Ministerial Meeting, March 20, 1933], 238-243, 239, where Hitler reports that in his discussion with the Center party they accepted his reasons for the enabling law and that they would vote for it, which - as he is pointing out - would be as very important regarding the German prestige towards foreign countries

${ }^{141}$ Hubatsch, Hindenburg, Doc. 106, Protocol of the cabinet meeting of March 20, 1932, 371-374

142 Hubatsch, Hindenburg, Doc. 105, Protocol of cabinet meeting on January 30, 1933, 369-371, where Hitler is stating, that they needed to eliminate the communist seats in the Reichstag in order to pass the enabling law and Hugenberg and Papen concur; also Hitler was afraid in case of a KPD-ban there could be a general strike, but the Reichswehr was not to be used in case of its suppression; their only focus was supposed to be on a foreign enemy; while the Foreign Minister, v. Neurath, proposed that a KPD-ban combined with a general strike needed to be avoided; in Doc. 106, 371-374, Minister of the Interior, Frick, is stating that in - order to pass the enabling act - they would have to change the procedures of the Reichstag, and count all the missing members as 'present' 
of day - may be able to connect with those people who are now separated from us but still believe in Germany. (...)"143 (emphasis by author)

Hitler's statement is a summary of his 'legal revolution' combined with threats and why he preferred a 'legalized' transfer of power compared taking power through a putsch - a case he had tried in 1923 and lost. He knew that he could only do it through constitutional measures (he had no interest in starting a civil war), in agreement with 'the powers that be' (Hindenburg) because he not only feared the Reichswehr (as Groener had pointed out), but he also figured that - in case of a legal appointment - potential resistance of social democrats and communists would be close to zero. Hitler knew that he needed to avoid a potential act of solidarity between the Reichswehr and his political adversaries, and he estimated that the social democrats would think twice calling for a general strike like during the Kapp-Luettwitz Putsch in 1920. In case the Nazis would have to take power violently, Hitler would have had the Reichswehr and more than half of Germany against him. This was a big risk that could cause a lot of 'problems' and the whole Machtergreifung could have failed.

The representatives of the catholic Bavarian People's Party (BVP) and the former liberal State Party (StP, now reduced to a small fringe), von Lex and Maier, enumerated the basic rights which they deemed part of Christian civilization and part of the Prussian tradition pointing out that they were missing these in the enabling act, but, aside of any guarantees by Hitler, considered that these objections were alleviated although not completely dispelled. In short, as informed citizens they had grave concerns about the fact that the "basic elements of any community living together in an orderly, constitutional state" 144 were shattered but felt compelled to vote for the act, because for several reasons they did not have the courage to do like the Social Democrats and vote 'no'. They probably hoped that a better future was just about to begin and things would not turn all that bad as many 'naysayers' had already promised.

Only a few National Conservatives (from the BVP) went to Hindenburg to complain about the potential consequences of the transfer of power of January 30, 1933, stating that the Nazis were striving to acquire "sole power"145, which should be prevented. Despite numerous complaints against methods and procedures of the Nazis, the shared goals in getting rid of the

\footnotetext{
${ }^{143}$ Hitler, Speech, Verhandlungen des Reichstags, Vol. 457, $2^{\text {nd }}$ Session, March 23, 1933, 36 (D); Bracher, Machtergreifung, 166

${ }^{144}$ Hitler, Speech, Verhandlungen des Reichstags, Vol. 457, $2^{\text {nd }}$ Session, March 23, 1933, 38 (A-C)

${ }^{145}$ Pyta, Hindenburg, 811-812
} 
parties on the Left and the pledge of rearmament seemed more important than their own future as independent political parties. ${ }^{146}$ The National Conservatives were fully aware, and being in support of an alliance with National Socialism, that the new regime would cause a change in Germany that would turn the country into a dictatorship. ${ }^{147}$ They accepted that random acts of violence against dissenters and Jews ${ }^{148}$, first spontaneously and later in established concentration camps ${ }^{149}$, would become the norm hoping it was not directed against themselves. The same attitude can be found in the Crown Prince, who showed up at the 'theatre coup' of Potsdam and two days later at the passing of the 'enabling act' in support of the common goals and the alliance of the Right in the spirit of 'national unity'. If he would have been a serious 'resister' he had no reason to show up at all and legitimize the events through his appearance.

In short, the Hohenzollern became supporters of the cause that helped to legitimize the transfer of power they were all striving for to leave the 'hated' republic behind. ${ }^{150}$ Not attending these crucial events would have documented their disagreement with the Nazis, like in the case of Ewald von Kleist-Schmenzin, who - as a conservative - even before January 30, 1933 went to warn Hindenburg and tried to prevent Papen and Hugenberg from making a

\footnotetext{
${ }^{146}$ As an example, AdR Hitler, Vol. I, Doc. 10, 15, 20, 23, 39, 40, 42, 51,58 (Hitler in an answer to Papen is denying any attacks of the SA on foreign dipolomats and is comparing them with the revolution of 1918, meaning any encroachments now are nothing compared with the 'crimes' of the 'November criminals' back then

${ }^{147}$ See also the diary of Reinhold Quaatz (DNVP), Die Deutschnationalen und die Zerstorerung der Weimarer Rpublik, aus dem Tagebuch von Reinhold Quaatz 1928-1933 [The German Nationals and the Destruction of The Weimar Republic, from the diary of Reinhold Quaatz], ed. Hermann Weiss and Paul Hoser (Berlin: Oldenbourg, 1989): 227-229, 234-243; Larry E. Jones, "Die Tage vor Hitlers Machtuebernahme, Aufzeichnungen des Deutschnationalen Reinhold Quaatz" [The Days before Hitler's Seizure of Power, Notes of the National Conservative Reinhold Quaatz], in: Vierteljahrshefte fuer Zeitgeschichte 37, no. 4 (1989): 759-774

148 The anti-Jewish actions, Christoph Dipper, "Der Deutsche Widerstand und die Juden" [The German Resistance and the Jews], in: Geschichte und Gesellschaft 9, no. 3 (1983): 349-380; Frank Bajohr, "The 'Folk Community' and the Persecution of the Jews: German Society under National Socialist Dictatorship, 1933-1945”, Holocaust and Genocide Studies 20, no. 2 (2006): 183-206; Hitler is trying to turn - what he calls the 'atrocity propaganda' in Foreign countries against the Nazis - into a boycott of Jewish businesses that they have to realize that this 'help' from Foreigners won't do them any good, AdR Hitler, Vol. 1, Doc. 78, Minister-besprechung vom 29. Maerz, 1933 [Ministerial Meeting, March 29, 1933], 270-273
}

${ }^{149}$ Christian Goeschel and Nikolaus Wachsmann, "Before Auschwitz: The Formation of the Nazi Concentration Camps, 1933-1939”, Journal of Contemporary History 45, no. 3 (2010), 515-534; Michael Wildt, "Die ersten 100 Tage der Regierung Hilters"[The First 100 Days of Hitler's Government], Zeitgeschichte online 7 (2017); Hermann Kaienburg, "Die Rolle von SA und SS in der Phase der nationalsozialistischen Machtkonsolidierung im Frühjahr 1933" [The Role of SA and SS in the first Phase of national socialistic Consolidation of Power in the Spring of 1933], 163-177; Kurt Schilde, "Opfer des NS-Terrors 1933 in Berlin" [Victims of the NS-Terror in 1933 in Berlin], both in, Kopke, Tress, Tag von Potsdam, 179-211; regarding the roots of antisemitism, Donald L. Niewyk, "Solving the Jewish Problem: Continuity and Change in German Antisemitism, 1871-1945", Leo Baeck Yearbook 35, no. 3 (1990): 335-370

${ }^{150}$ F. W. von Preussen, Hohenzollern, 207 
'serious mistake'. ${ }^{151}$ From the Crown Prince we only have statements and letters of agreement with the Nazis that signal the opposite. Wilhelm did not try to warn Hindenburg, nor did he try to prevent people he knew well from forming an alliance with Hitler. He did the opposite: he encouraged them to do so.

\section{The Crown Prince' letters and publications after January 30, 1933}

If the Crown Prince had been an opponent of Hitler one would at least expect a public silence after the seizure of power and privately scathing letters to his friends, but Wilhelm acted to the contrary. In fact, there is an identity between his private letters and public statements regarding the new NS-regime that demonstrates again that he was (as he wrote to his father on January 30, 1930) very excited about the transfer of power to Hitler. Wilhelm II. could not agree more and the Crown Prince was thrilled that finally in Germany "a new Government was inaugurated, that confirmed his efforts he has worked for since a year". ${ }^{152}$ And he continues (aside from public appearances like on the 'Day of Potsdam') to lend his name and prestige as a supporter of the Nazis. From his national and international public assistance, the letters to friends and family to the telegrams of congratulation to Hitler for his invasions of foreign countries in 1939-40 ${ }^{153}$, after January 30, 1933, Wilhelm followed enthusiastically the line of propaganda for the new regime and defended its course of trivializing and diminishing the violent and deadly measures against dissenters and Jews calling it 'countermeasures against a communist plot' ${ }^{154}$

In his report, Clark is focusing mainly on the two articles the Crown Prince had published in Germany called "November days" and "Eternal Prussia" in 1933, that were written as an encouragement for the NS-referendum for Germany to leave the Voelkerbund (united nations) in October 1933 that Clark is omitting in his report. He considers them as a "support of the new regime" but with the qualification that Wilhelm did not support the Nazis without certain limitations, emphasizing that he has stated that Hitler will act in the conservative tradition of Prussian politics. Clark is also conceding that the Crown Prince never defended the Jews, condemned publicly the alleged Greuelpropaganda (atrocity propaganda) against Germany in

\footnotetext{
${ }^{151}$ Scheurig, Kleist-Schmenzin, 119-125

${ }^{152}$ F. W. v. Preussen, Hohenzollern, 204

153 The original letters and telegrams can be viewed in facsimile, Arne Semsrott, "Der braune Adel und die Nazis: Wir veroeffentlichen die Briefe von Kronprinz Wilhelm an Hitler", in: www.fragdenstaat.de (Nov. 14, 2019)

154 “Ex-Crown Prince denies Atrocities", New York Times, 14
} 
foreign countries and was sharing the antisemitic prejudices of the Right. However, Clark is also stating that the impact of his opinions, Wilhelm has expressed in the German and foreign press, can only be considered "insignificant" and his private letters to Lord Rothermere and Geraldine Farrar where he positively supported the Nazis should be regarded as "megalomaniacal". 155

Wilhelm had - according to Clark - to many illusions about his own influence (Clark wants to downplay it), and the Crown Prince' telegrams of congratulations for Hitler's invasions of the neighbor countries from 1939 onwards, are presented in relation to an obvious justification, the 'material insecurity' the Hohenzollern allegedly had to deal with after 1933. In addition, Clark is seriously stating that the family was constantly confronted with the danger of expropriation of their estates ${ }^{156}$, an assertion, that he uncritically took over from the Crown Prince' grandson, Friedrich Wilhelm, which we will address further below. If the Crown Prince really would have been opposed to the Nazis, he would have had a choice, either being silent after 1933, or, like his younger brother Adalbert, could have stayed out of politics and moved to Switzerland before 1933, an option that Wilhelm never considered and that - as an alternative to supporting the Nazis - also did not seem to enter the mind of the authors of these reports.

Pyta/Orth argue in a similar fashion, admitting that Wilhelm published those articles in the domestic and foreign press, but insisted that these articles are not representative of his opinions because they are atypical for his true convictions. Instead, they are claiming that these articles need to be understood as "tactical concessions" considering that (in their view) Wilhelm is an opponent of Hitler who has only paid lip service to the Nazi cause. Regarding his letters to friends and family - if they are mentioned at all - they follow Clark and his thesis of 'megalomania', pointing out that these statements are insignificant because they never became public at the time.

In contrast to Clark and Pyta/Orth the reports by Brandt and Malinowski show with overwhelming evidence that Wilhelm's public and private statements in favor of the Nazis follow a certain 'line of plausibility'. If the Crown Prince would have really been in opposition to the Nazi seizure of power, he would not have written (besides any public statements) those incriminating private letters suggesting his support for the new regime,

\footnotetext{
${ }^{155}$ Clark, Report, 16

${ }^{156}$ Clark, Report, 5-6, 8-9, 10, 12-13, 14, 16-17
} 
including the telegrams of excitement to his father and the letters to Farrar and Rothermere. In his letter to Rothermere, he is also stating that he was already in favor of Hitler not only at the President's election in 1932, where he secured him about "two million votes", but also pointing out that he has asked Bruening to retire early, recommended Hitler as Hindenburg's successor and continued these efforts even under Chancellor Schleicher until Hitler was finally appointed. In Wilhelm's perspective this day was a great joy for every German:

"And thus the respect for, and the confidence in the personality of the Fuehrer Adolf Hitler grew from month to month. (...) All I can say is that on that day indescribable jubilation went through the whole German nation.” 157

The problem for both reports in favor of the Hohenzollern is that there are not only private letters in which Hitler and his policies were praised; in several public statements the Crown Prince helped the NS-regime to refute criticism from the United States and other countries where Jewish organizations complained about the boycott and mistreatment of Jewish people through SA-members. ${ }^{158}$ What Clark and Pyta/Orth do not mention is the fact that Wilhelm's letter to Rothermere, where he praised the politics of the Nazis, seem to be a calculated move to cover up the atrocities against hundreds of thousands of German citizens that suffered in concentration camps while the Crown Prince 'hobnobbed' with the perpetrators of this policy.

Also, through his letters, Wilhelm helped those NS-regime friendly, influential forces in Great Britain, represented by Lord Rothermere, to spread a positive picture of the Nazis in mass publications like the 'Daily Mail', the 'Evening Standard' and others. Rothermere was one of those friends of National Socialism that believed the only way to avoid another war and fight Bolshevism was friendly relations with Germany and giving the Nazis and Hitler a 'free hand' in the East, where they could fight communism to the 'benefit' of the Western World. Rothermere was not an accidental target to whom the Crown Prince sent a 'private' letter. The owner of the Daily Mail and other publications was a well-known Nazi supporter in England, who had praised the new Regime in several articles and Hitler - following the advice of Foreign Minister Neurath - invited him in December 1934 to a special dinner for foreign guests at the Reichskanzlei, where other influential people were also present. ${ }^{159}$

\footnotetext{
${ }^{157}$ Malinowski, Report, 36-37

158 “Ex-Crown Prince denies Atrocities", New York Times, 14

${ }^{159}$ Ian Kershaw, Hitlers Freunde in England. Lord Londonderry und der Weg in den Krieg [Hitler's Friends in England, Lord Londonderry and the Path to War] (Muenchen: DVA, 2005): 80-83, also see note 133 on p. 432
} 
As a result of this visit, more positive articles appeared in the Daily Mail, where Rothermere praised Hitler as a 'god given gift' to Germany and portrayed any critical reports regarding the treatment of Jews and opponents to the Nazi regime as utter nonsense. Hitler, understanding very well the potential value of his 'friends' in Great Britain, also send several letters to Rothermere trying to reassure him about his motives asserting his peaceful intentions as he implemented a policy of gradually undermining the Versailles Treaty. Hitler reaffirmed the cornerstone of this 'peaceful' strategy, getting what he wanted without a shot fired: his intention to establish friendly relations with Great Britain which was supposed to isolate France and give him a 'free hand' to gain new Lebensraum (room to live) for Germany in the East. Hitler hoped that Rothermere would show his letters to other influential people in Britain, expecting a breakthrough in British-German relations that would support his shared goals with the National Conservatives that Germany would become a great power again. ${ }^{160}$

In his private letters, the Crown Prince could be very frank about the measures of the Nazis which he called in a letter to Geraldine Farrar in April 1933 (a friend of his in America) "Aufraeumarbeiten" (clean-up work), which was a euphemism for the destruction of the 'Left' and the Weimar Republic. Specifically, in this letter to Geraldine Farrar - with a "HeilHitler" greeting and an official copy to Goebbels on April 11, 1933 -, the Crown Prince confirmed every conservative prejudice about the Weimar Republic and its founders, and at the same time launches a justification for the victorious 'upheaval' of the Nazis. Wilhelm is mad about the revolution in 1918, the fall of the monarchy and the defeat of the army, pointing out who is responsible for it, without pulling any punches, demonstrating his antisemitism and boosting the 'stab-in-the-back legend' that became one of the core features of the conservative and Nazi interpretation of the past:

"The unbelievably mean and vile revolution of 1918, in which socialists, deserters, slackers, war profiteers and unfortunately also a large part of the Jews of our fighting army fell in the backs of our fighting army and caused the revolution with the help of the unscrupulous elements of the fleet. The overthrow of the monarchy, the unheard-of peace treaty of Versailles, based on the swindle of Mr. Wilson's 14 points, and the unheard-of enslavement of the German people by the war tributes were the result of this revolution."161

\footnotetext{
${ }^{160}$ Kershaw, Hitlers Freunde, 82; regarding foreign policy, Ullrich, Hitler, 528-567, 754-838

${ }^{161}$ The letter is quoted extensively by Lothar Machtan, Der Kaisersohn bei Hitler [The Kaiser's Son with Hitler] (Hamburg: Hoffmann \& Campe, 2006), 291-292, 291
} 
Also, the Crown Prince is stating that all administrations that governed the republic subscribed to a "an endless policy of appeasement, which meant that the German people were driven into ever greater impoverishment and it was believed that by continually giving in and fulfilling all the demands of the enemy we could secure a better position for our fatherland among the other nations." 162 And after having to swallow these 'outrageous' policies for such a long time, it is no surprise - according to Wilhelm - that in National Conservative and NScircles a tremendous anger has pent-up and was now discharged against the republic and its representatives (social democrats, Jews and communists), that would also result in hardship and 'overacting'against individuals, but at its core - he assures Farrar - President Hindenburg and Chancellor Hitler (an uncrowned 'genius') were the guarantee that after the necessary Aufraeumarbeiten "very soon there will be complete quietude and tranquility in our fatherland." 163

The term 'clean-up work' was also a euphemism for the terror- and boycott campaigns against dissenters and Jewish businesses as well as the implementation of 'wild concentration camps' where SA-groups tortured and killed numerous people they wanted to eliminate, while the regular police who had tried to prevent this before now had an order from above to just look the other way. ${ }^{164}$ At this point SA and SS terror circles could do whatever they wanted using that permission leniently. The Crown Prince was fully aware of this, although in public he denied it and tried to play it down, calling it in an open letter to George S. Viereck (a NSpropagandist in America) 'anti-German' propaganda comparable to that during World War I, insinuating that these reports were basically untrue. Knowing well that people in America were also worried about communist activities, his address admitted falsely that any measures were only directed against communist' outcasts, using this as a blanket excuse to suspend the basic rights of the people:

"Reports that a state of siege and news censorship exists are free inventions. The emergency decree under which mail and telegraphic communications can be supervised is directed against persons suspected of communist plots. The national revolution, the goal of which it is to free Germany from serious communistic danger and remove from the administration all inferior elements, has been accomplished with remarkable order." 165

\footnotetext{
162 Machtan, Kaisersohn, 291

${ }^{163}$ Machtan, Kaisersohn, 292

${ }^{164}$ Kaienburg, "Rolle SA und SS”, 163-177

165 "Ex-Crown Prince denies Atrocities”, New York Times, 14
} 
The Crown Prince had no problem - for the purpose of German propaganda - to lie and manipulate his audience. On top of that, he pretended that he is acting like a neutral citizen instead of being a representative of the German Government with an official point of view, because the whole affair was coordinated with propaganda Minister Goebbels who gave Wilhelm in his diary a 'high five':

"Anti-German propaganda: Crown Prince is helping me quite a bit in sending an open letter to Viereck in New York which I have written and which will be cabled right away."166

In short, Wilhelm followed German propaganda directives created by Goebbels as part of a coordinated public relations campaign for the new regime. This was also acknowledged by German newspapers who widely reported about the success of German 'counter-measures' to Allied propaganda efforts to discredit Germany in the eyes of foreigners. Wilhelm is not only part and parcel of the German Propaganda campaign but is using his international contacts to legitimize the Nazi-regime in foreign countries, with whom Germany is directly involved and where statements of the Crown Prince did matter.

Also, Clark and Pyta/Orth seem to overlook the historical context of the Nazi foreign policy between 1933 and 1939. The initial policies of so-called 'peaceful' pressure and allegedly rightful 'self-determination' of German minorities in foreign countries turned into the a war of extermination against Poland and other countries starting in 1939. The Nazis 'peaceful' disguise and the strategy of 'Selbstverharmlosung'167 (to appear as harmless as possible) was finally terminated, and they initiated the attacks on Poland and other countries that turned into the Second World War while the conservative Elites of the Reich in the Foreign Office and the Wehrmacht did not object and followed Hitler, driven by their anti-Polish prejudices and the desire to destroy the Treaty of Versailles. ${ }^{168}$ Understanding how unpopular war would be - specifically after five years of a necessary peace rhetoric that Hitler already regretted ${ }^{169}$ -

\footnotetext{
${ }^{166}$ Goebbels, Tagebuecher (Diaries), 25. 3. 1933, quoted by Malinowski, Report, 27-28

167 Hans-Adolf Jacobsen, Nationalsozialistische Aussenpolitik 1933-1938 [National Socialist Foreign Policy, 1033-1938] (Frankfurt/M.: Metzner Verlag, 1968): 328

168 Klaus-Juergen Mueller, "Zu Struktur und Eigenart der nationalkonservativen Opposition bis 1938 Innenpolitischer Machtkampf, Kriegsverhinderungspolitik und Eventualstaatsstreich" [On the structure and character of the National-Conservative Opposition until 1938 - domestic Power Struggle, War Prevention Policy and eventual Coup d'état], in: Schmaedeke, Widerstand, 329-344; Gerd Ueberschaer, "Militaeropposition gegen Hitlers Kriegspolitik 1939 bis 1941 - Motive, Struktur und Alternativvorstellungen des entstehenden miltaerischen Widerstandes" [Military Opposition to Hitler's War Policy 1939 to 1941 - Motives, Structure and alternative Ideas of the emerging Military Resistance], in: Schmaedeke, Widerstand, 345-367, 347-348
}

${ }^{169}$ As Hitler has stated in a secret speech to the German Press, Wilhelm Treue, "Hitlers Rede vor der Deutschen Presse (November 10, 1938)" [Hitler's Speech to the German Press, November 10, 1938], Vierteljahrshefte fuer Zeitgeschichte 6, no. 2 (1958): 175-191, 180 
the Nazis created several Grenzzwischenfaelle (border incidents) in Silesia ${ }^{170}$, that were supposed to show that Poland had attacked Germany and not the other way around, a recipe that has already been used by their predecessors in unleashing the First World War.

Instead of criticizing the Nazi regime for starting the war with Poland, Norway and France, Wilhelm congratulated and praised the 'success' of the Fuehrer on June 25, 1940, for his "brilliant leadership" in overwhelming and invading Belgium, Holland and France and suggested "a final settlement with the perfidious Albion". And, "in this hour of historical significance as a soldier and a German I would like to shake your hand with full admiration."171 Already on September 21, 1939, three weeks after Germany had invaded Poland, the Crown Prince had sent a hand-written letter to Hitler, stating 'neutrally' like the Nazi propaganda slogans - after peace could not be 'sustained' and Germany had to resort to arms - he wanted to express "his sincere and warmest wishes" regarding the success of the Wehrmacht in Poland, that every "soldier's heart makes beat faster" and that he and his sons would be delighted to become a soldier again with the sincere hope to be employed in this war. ${ }^{172}$

As we have shown before, the Crown Prince was always in Hitler's camp and was neither protesting nor was he in opposition to the regime. There were other conservatives, like in the case of Fritz Thyssen, a Ruhr magnate, who also had supported Hitler previously, but, in disagreement over the war against Poland in $1939^{173}$, initiated a complete break with the NSmovement, while Wilhelm - despite his experience in July 1934 - chose the opposite and continued his support for the 'German' cause. For Thyssen, the decision for war against Poland seemed a big mistake (the 'beginning of the end'), while for the Crown Prince the 'basic consensus' ${ }^{174}$ with Hitler about the common goals in foreign policy aside of any differences in timing and methods, still prevailed. As the Nazis were successfully subjugating Europe, the Crown Prince like the overwhelming majority of National Conservatives and

\footnotetext{
${ }^{170}$ A detailed account of these activities, Alfred Spiess, Heiner Lichtenstein, Unternehmen Tannenberg; Der Anlass zum Zweiten Weltkrieg [The Tannenberg Enterprise, the Pretext for World War II] (Frankfurt/M., Ullstein, 1979)

${ }^{171}$ F. W. v. Preussen, Hohenzollern, 222

${ }^{172}$ Quotes from Brandt, Report, 34-35

${ }^{173}$ Hans O. Eglau, Fritz Thyssen, Hitlers Goenner und Geisel [Fritz Thyssen, Hitler's Patron and Hostage] (Berlin: Siedler, 2003): 203-241

174 Klaus-Juergen Mueller, "Deutsche Militaer-Elite", in: Broszat, Schwabe, Eliten, 285-289, 289: "This consensus was also not in danger, when Hitler in 1941 initiated the attack on the Soviet Union as a racemotivated war of annihilation."
} 
Germans in general willingly followed the path of conquest and destruction and showed no interest in opposition or even resistance, except for a few individuals.

\section{The restoration of the monarchy}

One of the motives consistently referenced in the reports supporting the claims of the Hohenzollern and used as an excuse for the Crown Prince' dealings with Hitler and the Nazimovement, is the blanket statement that he was only cooperating with National Socialism because he saw an opportunity to restore the monarchy in Germany, combined with the hint that the Fuehrer had confirmed many times that he had similar intentions. ${ }^{175}$ Aside of the fact that this is no 'good' excuse or reason for supporting the Nazis, this point needs to be further investigated. The Crown Prince may have drawn his own conclusions before 1933 although he had doubts - as Bruening reports ${ }^{176}$ - but stated after Hitler's seizure of power that he had lost faith in the chance for a restoration. ${ }^{177}$ After 1945, during an interrogation by Robert M. W. Kempner while testifying in Nuremberg at the so-called Wilhelmstrassen trial (Case No. 12), Wilhelm confessed that he never believed Hitler, and thought that his statements regarding the restoration of the monarchy were a deliberate deception by the Fuehrer. ${ }^{178}$ That he may have had certain hopes called 'illusions' - and that he even tried to coopt Rothermere for that ${ }^{179}$ - may be true, but it doesn't change his support for the 'Fuehrer' or his general belief that this support - aside of the restoration question - was the right thing to do and that both parties - the Crown Prince and the Nazis would benefit from it.

For Wilhelm's biographers Herre and Jonas (as well as Clark and Pyta/Orth) the restoration issue seems like a valid explanation for his support of the Nazi cause before and after $1933^{180}$,

\footnotetext{
175 Regarding Hitler's intentions and policies from a contemporary perspective, G. E. W. Johnson, "Hitler or Hohenzollern?", The North American Review 238, no. 3 (1934): 513-523

${ }^{176}$ Bruening, Memoirs, reports a meeting with the Crown Prince regarding the restoration of the monarchy, 520: "But he [Wilhelm] believed that I would fail anyway, because in his opinion the problem was the character of the Reich President, who would betray me as much as he would have betrayed everyone else, he did not even think of making room for a monarch."

${ }^{177}$ F. W. v. Preussen, Hohenzollern, 207-208, 210; Jonas, Kronprinz, 242

178 Jonas, Kronprinz, 290-295, 291

${ }^{179}$ Machtan, Kronprinz, S. 223

${ }^{180}$ While Herre, Kronprinz Wilhelm, 176, 199, 202, 214, 220-223, 226, and Jonas, Kronprinz, 216-217, 222, 236, 239, 242, 247, still points towards the importance of the restoration concept for the Crown Prince' motives; Jonas is also saying that Wilhelm didn't believe in it after Hitler's seizure of power, that publications for NSPropaganda probably were made against his will and is guessing that he was restrained by financial dependency on the Nazi's good will regarding his properties, 242-243, 251
} 
suggesting indirectly that this was his only motive. The Crown Prince' grandson Friedrich Wilhelm (thirty years later) dropped that line of excuse and focused more on potential expropriation threats ${ }^{181}$ (also eagerly picked up by Clark $^{182}$ ). They all characterize the hope for restoration was an illusion that the Crown Prince was clinging to and point out that it was unrealistic from the beginning, insinuating that he did not realize this during the 'dark' years, and has supported Hitler out of a neccessity. But the question remains, when did the restoration issue become unrealistic? Already during the war of 1914-18, when the Kaiser avoided his responsibilities as commander-in-chief and rather chopped wood and went for walks until Germany's defeat became unavoidable? ${ }^{183}$ Or when Wilhelm II. and the Crown Prince - as a result of the defeat and the 'revolution' in Germany - signed their abdication in $1918^{184}$ avoiding responsibility as the supreme leader and fled into exile? At the President's election in 1932 when Wilhelm II. did not permit the Crown Prince' candidacy to go forward $^{185}$ ? When Hitler in March of 1933 told the public that a restoration would be out of the question with the Crown Prince being present ${ }^{186}$ ? After the Roehm affair in 1934 or finally when Alfred Rosenberg stated in 1939 that "the monarchy has been sunk into a grave forever" because in 1918 the Kaiser himself through his abdication had left that tradition behind? ${ }^{187}$

It is important to find an answer because, if the Crown Prince had serious doubts before 1933, it is nothing more than a non-convincing, lame excuse to use the restoration issue as an explanation for his support of National Socialism. Clark, for example, points out that Hitler confirmed the restoration of the monarchy whenever he needed the Crown Prince to be in support of the Nazis (for example before the President's election in January 1932), but then states that Hitler favored Wilhelm's brother August Wilhelm and his son Alexander as a successor in the next generation, admitting that the Fuehrer was effectively postponing the

${ }^{181}$ F. W. v. Preussen, Hohenzollern, is emphasizing the failure of the efforts of Wilhelm II. and the Crown Prince by 1933, as the Nazis curbed any monarchical organization in 1934, 120-129, 201-202, 207, 210, 215, 222-223, and is guessing that Wilhelm could not be too critical of the Nazis having to show restraint because he was worried about potential interventions by the regime towards his properties according to the enabling act, 212, 223

${ }^{182}$ Clark, Report, 15-16

${ }^{183}$ Michael Epkenhans, "Der Verfall des monarchischen Gedankens in Deutschland im Ersten Weltkrieg" [The Decline of Monarchical Thought in Germany during the First World War], in: Globale Machtkonflikte und Kriege, ed. Flavio Eichmann (Paderborn: Schoeningh, 2016): 175-192

184 “The Former German Emperor”, Current History 9 (March 1, 1919): 437-439

${ }^{185}$ Stribrny, Kandidatur, 198-212

${ }^{186}$ F. W. v. Preussen, Hohenzollern, 253, is quoting Hitler's speech on March 23, 1933

${ }^{187}$ F. W. v. Preussen, Hohenzollern, 255 
issue. ${ }^{188}$ Pyta/Orth go a step further and assert that even during the time when Bruening was looking for an alternative candidate for Hindenburg, only the Crown Prince came to mind, and Bruening and Schleicher were courting him ${ }^{189}$, as the former has allegedly stated in his memoirs.

However, looking at Bruening's memoirs a different picture emerges. First, the meeting with the Crown Prince was proposed by Schleicher and Bruening followed him with hesitation, because, as we know from other parts of the memoirs, Bruening was not thinking very highly of Wilhelm. ${ }^{190}$ Secondly, at the meeting, the Crown Prince balked at the idea that in this situation the restoration of the Monarchy would depend on the support of the 'Left' and third he was convinced that Bruening's plan would fail. As Wilhelm has pointed out at the time, the crucial factor in all of this, Hindenburg, would betray - in his mind - all of them anyway, as he had done before, because Hindenburg had no interest in vacating his office for a future monarch, except for Wilhelm II., which was out of the question anyway. ${ }^{191}$ This statement shows that in Spring of 1932 the Crown Prince (beyond any hopes and illusions) was aware of one of the crucial obstacles, and the difficulties in overcoming that. It sounds like that Wilhelm already had no faith in the restoration of the monarchy before he became a candidate for President.

In fact, the available documents suggest that the Crown Prince was very realistic about the restoration question, as Jonas reports and Wilhelm's grandson reiterates. ${ }^{192}$ Clark states that Wilhelm nevertheless believed in it even after the seizure of power stating that Hitler in May 1933 continued to nurture the idea that - as a "completion of his work" - he would like to see the restoration of the monarchy and the Hohenzollern dynasty would be his only choice. ${ }^{193}$ However, Clarks statement where he is quoting Friedrich Wilhelm von Preussen is incomplete. Already on the following pages of his study, Friedrich Wilhelm is pointing to a meeting Hitler's with Friedrich von Berg, a member of the Hohenzollern administration, where the Fuehrer remarked, consistent with his speech on March 23, 1933, that he is not refusing "a

\footnotetext{
${ }^{188}$ Clark, Report, 8

${ }^{189}$ Pyta/Orth, Report, 14

190 Bruening, Memoiren, 453, 512 is describing a meeting with Hindenburg who envisions a solution that involves the sons of the Crown Prince, while he is also refusing any solution for a restoration in general (except with Wilhelm II.), which means that Hindenburg was - like Hiler - effectively against a restoration and wanted to postpone it indefinitely

${ }^{191}$ Bruening, Memoiren, 520-521; Pyta, Hindenburg, 749

${ }^{192}$ Jonas, Kronprinz Wilhelm, 242; F. W. v. Preussen, Hohenzollern, 210

${ }^{193}$ Clark, Report, 8
} 
monarchy for the Reich in absolute terms, but as long as he lives, it would be out of the question, because the people only want him, Hitler, and nobody else." 194

Hitler added that only he and the NS-movement had the 'determination' to do the 'dirty work' (getting rid of the dissenters and starting a war), being very distinct about the question of restoration that did not nurture any illusions for the future anymore. At least since Hitler's speech in March of 1933 (where Wilhelm was present at the Reichstag) or the conversations Hitler had with the representatives of the Hohenzollern administration in May 1933, the Crown Prince could not have any more delusions about the feasibility of restoration because the Fuehrer had stated that this was never going happen "during his lifetime". Wilhelm's motive to continue working with the Nazis even after Hitler denounced any plans for a restoration must have had other reasons that obviously Clark and Pyta/Orth are not mentioning because they do not want to address it. ${ }^{195}$

As the Crown Prince stated himself, he was convinced that only Hitler with his 'energy and will' would be the one who could succeed in seizing power (in addition of any goals that national conservatives and Nazis had in common). This made him cooperate with the Nazimovement, becoming their domestic and international propaganda mouthpiece and made him praise the 'Fuehrer' with whom he felt he had a great relationship. As he explained in his letter to Lord Rothermere in 1934 there were several reasons why he was attached to the Fuehrer, aside of the point that a lot of Germans "saw in him a savior of our people" thinking that Hitler was a genius. Wilhelm was fascinated about Hitler's general posture in contrast to conventional politicians, admitting that he was an 'early adopter':

“General v. Seeckt, Stresemann, Bruening, and General von Schleicher, all of whom I cannot deny the recognition of their great abilities and best intentions, had never shown the will and the energy, required for all really thoroughgoing action. Thus, I also joined Adolf Hitler, already at the time, when wide circles of the Stahlhelm and particularly of the German nationalists refused to recognize him." 196

\footnotetext{
${ }^{194}$ F. W. v. Preussen, Hohenzollern, 121-122

${ }^{195}$ Pyta, Hindenburg, 749, decribes the activities of the Kaiser to intervene with Hindenburg through Mackensen in November 1932

${ }^{196}$ Karina Urbach, "Nuetzliche Idioten, die Hohenzollern und Hitler" [Useful Idiots, the Hohenzollern and Hitler], in: Preußendämmerung, Die Abdankung der Hohenzollern und das Ende Preußens, ed. Thomas Biskup, Truc Vu Minh, Jürgen Luh (Heidelberg: Arthistoricum, 2019): 65-93
} 
There were other problems with the restoration: The former Kaiser ${ }^{197}$ and the Crown Prince ${ }^{198}$ had signed a document in November 1918, that they would seal the abdication of their claim to be the King of Prussia or the Kaiser of the German Reich, which weighed heavily on their later demands to regain their former position, or when the Crown Prince aspired to be a serious contender for the throne. The issue was that Germany had three generations of Hohenzollern who wanted to become the next Kaiser, and as result there was only another obstacle for serious restoration attempts, because each of the contenders indirectly blocked the other's candidacy.

In connection with Wilhelm's intention to restore the monarchy, Clark is also mentioning another motive to cooperate with Hitler, speculating about the reasons why Wilhelm was sending the telegrams to congratulate Hitler on the invasion of the neighbor countries in 193940. Clark is pointing out, that the Hohenzollern family from 1934 on lived in constant insecurity about her financial well-being because parts of the regime (as rumors had it according to Clark) contemplated their expropriation, a threat that was supposed to be very real and should explain the strong drive of the family to keep good relations with the Nazimovement ${ }^{199}$. Thereby, Clark is touching upon a dark area of the Hohenzollern legacy: the net worth of the family, its income and distribution between its members and the financial assets which are shrouded in secrecy - until today. ${ }^{200}$

Clark is basing his verdict only on the assertion of Wilhelm's grandson, who in his study is mentioning a "complex web of dependencies" the Crown Prince had to face who needed to consider the "security of the family properties and therefore the good-will of the Nazileaders". ${ }^{201}$ Clark is quoting an adjutant of Wilhelm's father, Sigurd v. Ilsemann ${ }^{202}$, who is the

\footnotetext{
${ }^{197}$ Sally Marks, “'My Name Is Ozymandias': The Kaiser in Exile”, Central European History 16, No. 1 (1983): 122-170, John C. G. Roehl, Wilhelm II., Into the Abyss of War and Exile, 1900-1941, transl. Sheila de Bellaigue, Roy Bridge (Cambridge: Cambridge University Press, 2014): 1164-1187; Lothar Machtan, Kaisersturz. Vom Scheitern im Herzen der Macht [The fall of the Kaiser, from the failure at the heart of power] (Darmstadt: Wissenschaftliche Buchgesellschaft, 2018); "The Former German Emperor", Current History 9 (March 1, 1919): $437-439$

198 Jonas, Kronprinz, 170-172, F. W. v. Preussen, Hohenzollern, 193-194

${ }^{199}$ Clark, Report, 15-16

${ }^{200}$ Regarding the finances of the Hohenzollern there is only a small amount of information available, John C. G. Roehl, "Hof und Hofgesellschaft unter Kaiser Wilhelm II."[Court and its Society under Kaiser Wilhelm II.], in: John C. G. Roehl, Kaiser, Hof, Staat, Wilhelm II. und die deutsche Politik [Kaiser, court, state, Wilhelm II and German politics] (Muenchen: C. H. Beck, 1987): 78-115
}

${ }^{201}$ F. W. v. Preussen, Hohenzollern, 218

${ }^{202}$ Sigurd v. Ilsemann, Der Kaiser in Holland, Vol. 2: Monarchie und Nationalsozialismus, 1924-1941 [The Kaiser in Holland, Vol. 2: Monarchy and National Socialism], ed. Harald von Koenigswald (Muenchen: Biederstein, 1968): 235 
sole source of the "rumors" about the "expropriation" dangers by the Nazis ${ }^{203}$, but is sceptical regarding the chances for a restoration, considering Hitler's speech at the Reichstag on March 23, 1933, pointing in general towards the illusions that have have been promoted in the Kaiser's surroundings. ${ }^{204}$ Jonas is mentioning the danger of expropriation as well, but admits it is all speculative ("we don't know") and assumes it while he is looking for an explanation why the Crown Prince is still 'hobnobbing' with the Nazis after his good 'friend' Kurt v. Schleicher was killed by the regime in 1934.

All this remains speculative, because nobody is quoting any documents from the archives of the Hohenzollern administration, Friedrich Wilhelm v. Preussen had certainly access to and would have relied on if the danger had been real. Clark's additional claim that the Crown Prince and his family constantly lived in 'material insecurity' is inaccurate and should be clearly refuted or supported by incontrovertible evidence other than rumors. After the Kaiser abdicated in 1918 and fled to Holland, he was cut off from his fortune in Germany and, as several press reports and discussions in the Landtag (State Parliament) of Prussia indicated, he did not have to starve in his exile in Holland because the Government of Prussia sent him up to 100 Million Marks in several installments. ${ }^{205}$ The Kaiser, through the threat of returning to Germany, even managed to receive more funds in the early 1920s besides the 50 train wagons full of furnishings that were sent to him from Berlin to his new residence. ${ }^{206}$ There were estimates of his wealth in 1913 of 140 million ${ }^{207}$ Marks, and in 1921 of 1 billion with an annual income of 33 Million Marks ${ }^{208}$. Jonas is reporting that his fortune at the time of his death in 1941 was estimated at 70-80 Million $^{209}$ (ca. 15 times more in today's value) without giving any figures for annual income of the Hohenzollern for the time between 1933 and 1945.

\footnotetext{
${ }^{203}$ F. W. v. Preussen, Hohenzollern, 211

${ }^{204}$ Ilsemann, Kaiser in Holland, Vol. 2, 214-215, 216; Ilsemann states, that - after Hitler's statements in 1933 the Kaiser knew it was over

205 T. R. Ybarra, "Footing the Bills for Germany's Imperial Spendthrift”, New York Times, September 25, 1921: 40, listing the installments sent to Holland in 1918-1920; "100,000,000 Marks sent to Kaiser in Exile, Prussian Socialists demand List of House Furnishings forwarded to Doorn Mansion”, New York Times, November 5, 1920, 17

206 Cyril Brown, "Kaiser threatened to return to Germany, used that Argument to force Prussia to send more Money”, New York Times, Aug. 4, 1921, 2; further details, Kurt Heinig, Hohenzollern (Berlin: Verlag fuer Sozialwissenschaft, 1921); Roehl, Hofgesellschaft, 80-87

${ }^{207}$ Roehl, Hofgesellschaft, 83-85

208 “The Hohenzollern Fortune”, Current History 13 (Feb. 1, 1921): 274-277, 276

209 Jonas, Kronprinz, 287
} 
But even if we take Jonas' lower numbers, it seems clear that even at a lower annual income the Crown Prince (when after 1945 90\% of the real estate was lost and the Hohenzollern administration cut his income by $80 \%$ ) was able to rent a vacation villa in Switzerland for several months at 10,000 Swiss Francs per month, when foreign currencies were hard to come by. ${ }^{210}$ It is difficult to imagine (as Clark and others have suggested) that before 1945 when Wilhelm's usual annual income was still intact, that his family had to suffer from any material hardship or insecurity, and after 1945 , when he had lost $80 \%$ of his income, was even able to spend large sums on vacation homes.

\section{The conservative opposition to Hitler}

When dealing with the motives of the Crown Prince and his circle, Clark's strategy is to call Wilhelm a 'megalomaniac', characterizing him as a "pure Mitlaeufer"211 (fellow traveler), an opportunist, whose statements cannot be taken seriously. The term Mitlaeufer was used after 1945 to put people in the lowest possible category that determined they had done nothing wrong, have not been members of the party and had just gone 'with the flow'. People in this category were discharged and received - as it was called in German - a Persilschein, comparable to an acquittal in a court case that is about the opposite of support or advancement of a certain cause.

Pyta/Orth take it one step further (like the attorney for the Hohenzollern ${ }^{212}$ ) and argue that the Crown Prince and Kurt von Schleicher were not only not 'significantly advancing' Hitler and the Nazis but were determined to prevent him from coming to power ${ }^{213}$ and should be counted as part of the opposition against the regime. ${ }^{214}$ Their methodology is quite simple; instead of looking at the main events between November 1932 and January 30, 1933 and related documents, they are going one or two tiers below to find new evidence to reconstruct certain activities that by itself cannot be disputed but have no relevance for the bigger picture. In

\footnotetext{
${ }^{210}$ Jonas, Kronprinz, 296-297

211 Clark, Report, 16

212 Malinowski, Report, 20-21, points out that the attorney for the Hohenzollern, Putzier, has asserted in 2013 that the letters between the Crown Prince and Kurt v. Schleicher demonstrate, "that Crown Prince Wilhelm didn't want to enable a national socialist administration, and on the contrary wanted to prevent it" (just like Pyta/Orth in their report), while Malinowski calls it a "gross distortion of the real events which are well documented by research and primary sources"

${ }^{213}$ Pyta/Orth, Report, 4, 7, 29, 30, 35, 40, 42, 44, 94, 143

${ }^{214}$ Pyta/Orth, Report, 90-105, 98-100,
} 
addition, they are addressing the possible influence of certain events in a 'what, if' scenario, admitting its hypothetical character, but making it look like that they could count as a real alternative. ${ }^{215}$

The problem with this scenaerio is its hypothetical character and potential impact; Pyta/Orth claim it could have been useful if Gregor Strasser, their candidate of resistance before 1933, would have internally fought against Hitler. May be, but - and this is the problem with this claim - Strasser quit already on December 8, 1932, before the fight had eally begun. However, through this early surrender in December ${ }^{216}$ and his hesitation in January to join a Schleicher cabinet the information the Crown Prince provided about certain develpments in the Nazi party was rendered useless, aside of the problem if providing this information could qualify as a 'prevention of Hitler'. The conclusion that Wilhelm played an important role to prevent Hitler from coming to power, because he was 'crucial' for Schleicher's alleged concept to potentially split the NS-Party and work with Strasser, is without any plausibility and remains highly speculative. No matter how we look at it, it remains a 'what, if' scenario, that is in contradiction to the conclusions Pyta/Orth are drawing from it. ${ }^{217}$ In reality, none of these activities had a crucial impact on Schleicher's strategy to stay in power, on the events in January 1933 or on Hindenburg appointing Hitler as the new Chancellor on January 30, 1933.

As we have already emphasized, the real resistance to Hitler was concentrated in the former Government of Prussia, that Papen and Schleicher had finally eliminated on July 20, 1932 and therefore all opposition was restricted to the Social Democratic party, that was out of office and powerless. The real reason why Schleicher's concept of a Querfront ${ }^{218}$ (transverse front)

\footnotetext{
${ }^{215}$ Hentschel, Weimar, Doc. II, "Briefe vom Leiter des Wehramts der NSDAP, General Hörauf, an den Kronprinzen Wilhelm", 150-154, in fact Hoerauf's letters to the Crown Prince are not only speculative but invalidate the core issue of Pyta/Orth, that Schleicher wanted to split the NS-party, in pointing out - on Dec. 13, 1932 - that the current Government could not have any interest in the split or demise of the NSDAP, 'because of the numerous valuable forces present in it, and because she has actually understood to bring back a considerable part of the workers into the national camp, who otherwise would go to the Left' (p. 152)

${ }^{216}$ Udo Kissenkoetter, Gregor Strasser und die NSDAP [Gregor Strasseer and the NSDAP] (Stuttgart: DVA, 1978): 123-177

${ }^{217}$ Pyta/Orth, Report, 41-42

${ }^{218}$ Henry A. Turner, "The Myth of Chancellor v. Schleichers Querfront Strategy", Central European History 41, no. 4 (2008): 673-681; Jasper, Zaehmung, 115-125; Axel Schildt, Militärdiktatur mit Massenbasis, die Querfrontkonzeption der Reichswehrführung um General von Schleicher am Ende der Weimarer Republik [Military Dictatorship with a Mass Base, the Transverse Conception of the Reichswehr Leadership around General von Schleicher at the End of the Weimar Republic] (Frankfurt/M.: Campus, 1981); Irene Strenge, Kurt von Schleicher: Politik im Reichwehrministerium am Ende der Weimarer Republik [Kurt v. Schleicher, Politics at the Ministry of the Reichswehr at the End of the Weimar Republic] (Berlin: Duncker \& Humblot, 2006): 198218; Reinhard Neebe, Grossindustrie, Staat und NSDAP 1930-1933 [Big Industry, the State and NSDAP, 193033] (Goettingen: Vandenhoeck \& Ruprecht, 1981): 140-152
} 
did not have a chance from the start and was only an Intermezzo (as Pyta has called it previously ${ }^{219}$ ), can be traced back to the problem that Schleicher was promising too much to too many organizations and people at the same time. He did not solve any of the problems regarding the national 'unity' Hindenburg had in mind or any other problems regarding the Reichstag that were urgent in January of 1933. Schleicher failed despite high expectations, because he could not deliver anything and was basically helpless to even manage the next session of the Reichstag. There he would face a motion of no confidence which was supported - comparable to that against Papen on September 12, 1932 - by over $90 \%$ of the Reichstag members. But Schleicher not only lacked the savviness of a regular politician to stay in power, his general flexibility regarding the structure of the state (as Pyta/Orth emphasize ${ }^{220}$ ) also worked against him, considering that he completely underestimated the Nazi party. He often compared it falsely with the Social Democrats during the Kaiserreich of the 1880 s or their entry into the Government in $1918 / 19$ trying to justify why the establishment needed to give Hitler and the NS-movement a chance to prove themselves. ${ }^{221}$ This comparison alone is not a sign of political cleverness but demonstrates political naivete as one of the factors that limited Schleicher's reign as a Chancellor to less than two months.

In addition, looking at Schleicher's relation to the NS-movement, it is a fact that since October 1931, when Schleicher initiated the first meeting with Hitler (and between Hitler and Hindenburg), it was Schleicher who was one of the most ardent supporters of bringing Hitler and the Nazi-party into the Government. Negotiating an agreement with Hitler on May 7, 1932, he proposed forming a coalition with the Nazis, cancel the SA-ban, dissolve the Reichstag and initiate new elections for the promise of 'support' of the new PapenGovernment, a promise Hitler conveniently overlooked later. After the successful election of July 1932, where the Nazis achieved $37,4 \%$ of the votes, Schleicher was the first who offered Hitler the Chancellorship stating that this would end the Nazi demagoguery and separate the party from the SA and the SS. Schleicher also saw the advantages of having a large Nazifaction in the Reichstag, considering that their votes would protect the military budget and instill fear on the Left that would keep the Social Democrats in check. ${ }^{222}$

\footnotetext{
219 Pyta, Hindenburg, 769

${ }^{220}$ Pyta/Orth, Report, 7-11

221 Peter Hayes, “A Question Mark with Epaulettes? Kurt von Schleicher and Weimar Politics", Journal of Modern History 52, no. 1 (1980): 35-65, 38-39, 48

${ }^{222}$ Hayes, Schleicher, 44-50
} 
To sum it up, in order to support Hindenburg's concept to achieve a more right-wing administration, Schleicher, as the representative of the President, was involved in all of the negotiations with the Nazis since 1931 (except the last one between Papen and Hitler when he was the Chancellor) and the plot to overthrow Bruening, the putsch against Prussia on July 20, $1932^{223}$ and the demise of Papen in November of 1932, when he used civil war preparations of the Reichswehr to scare the ministers in the Papen-cabinet to vote against a renewal of Papen's Chancellorship ${ }^{224}$. Pyta/Orth, construing the 'resistance'of the Crown Prince and Schleicher, are also omitting statements Schleicher has made that would completely change the picture as somebody who allegedly wanted to prevent Hitler from coming to power. Even after his demise on January 28, 1933 he told his cabinet at its last session, Hitler should become Chancellor, also hoping that he could at least stay on as a potential Minister of the Reichswehr in a Hitler cabinet. The protocol of this last cabinet meeting reads as follows:

"He, the Chancellor, fears the worst for the near future. The difficulties might not be so great if the President could find himself ready to appoint Hitler as Chancellor. To his knowledge, the Reich President was still not determined to do so. All that remains is the formation of a differently composed presidential cabinet, which, according to him, has so far being consisted of Papen and Hugenberg." 225 (emphasis by author)

In short, even at the end of January 1933, Schleicher outed himself as a reactionary opportunist that hoped that Hindenburg would appoint Hitler and that he could continue as a Minister of the Reichswehr. Despite his pragmatism and his flexibility, Schleicher was also a conservative preferring an authoritarian solution to the uncertainties of democracy. Unlike Papen, he agreed with parts of the NS-party (Strasser etc.) and others on social issues. It was also his goal to eliminate SPD and KPD and integrate the unions and the large group of workers, who were still voting for the left that could not be reached by the Nazi Party or the Konservative Volkspartei (Peoples' Conservative Party). This new small, conservative party, split from the DNVP in $1928^{226}$, because its protagonists could not accept Hugenberg's right-

\footnotetext{
${ }^{223}$ Strenge, Kurt v. Schleicher, 118-121

${ }^{224}$ Richard Breitman, “On German Social Democracy and General Schleicher 1932-33”, Central European History 9, no. 3 (1976): 352-378; Vogelsang, Reichswehr, 316; Larry E. Jones, "Taming the Nazi beast, Kurt v. Schleicher and the End of the Weimar Republic", in: From Weimar to Hitler: Studies in the dissolution of the Weimar Republic and the Establishment of the Third Reich, 1932-34, ed. Hermann Beck, Larry E. Jones (New York: Berghahn, 2019): 23-51, 28-29

${ }^{225}$ AdR Schleicher, Doc. 71.1, 307; Winkler, Weimar, 585

226 On the split of the DNVP, Thomas Mergel, "Das Scheitern des deutschen Tory-Konservatismus, die Umformung der DNVP zu einer rechtradikalen Partei, 1928-1932"'The Failure of German Tory Conservatism, the Change of the DNVP to a right-wing radical Party, 1928-1932], Historische Zeitschrift 276, no. 3 (2003):
} 
wing course without a 'social conscience', became Schleicher's sole supporters to help implement his Querfront concept, that unsuccessfully tried to unite the 'left' wing from different parties and the unions to encompass traditional party and class conflicts to provide a mass basis for a government that relied on the Praesidialsystem (Presidential system) and its emergency decrees.

The People's Conservatives and their representatives operated with similar ideas like the Nazis looking for a "new State" and a "Third Reich", although their concept to form a new Volksgemeinschaft was not necessarily based on terror and intimidation. ${ }^{227}$ Therefore, it is not accidental that a person like Guenther Gereke, who had designed Schleicher's program for job creation and was a forerunner of the ideas of Hans Zehrer ${ }^{228}$ from the Tatkreis, also became a Reichskommissar for job creation in Hitler's first cabinet, following a program, that fought unemployment with deficit-spending as an answer to one of the most crucial concerns since the economic crisis ensued in 1929. At the same time, the 'People's Conservative party' faction in the Reichstag (although quite small) voted for the enabling act without any reservations. ${ }^{229}$

In the aftermath, Schleicher tried to defend himself against Nazi allegations that he was the one who tried to delay a transfer of power to Hitler and pointed out, that since the Summer of 1931 he was promoting a participation of the Nazi party in Government and after the election of July 1932 vigorously pushing for Hitler becoming Chancellor. This assertion is also confirmed by contemporary source ${ }^{230}$, but - as Schleicher stated with regret - this move was prevented by Hindenburg and not by him. ${ }^{231}$ Schleicher only took Hindenburg's refusal in

323-368; Friedrich Hiller v. Gaertringen, "Die deutschnationale Volkspartei" [The German National People's Party], in: Das Ende der Parteien 1933, ed. Erich Matthias, Rudolf Morsey (Duesseldorf: Droste, 1960), 543652; Larry E. Jones, "German Conservatism at the Crossroads, Count Kuno von Westarp and the Struggle for Control of the DNVP, 1928-30", Contemporary European History 18, no. 1 (2009): 147-177; Erasmus Jonas, Die Volkskonservativen 1928-1933, Entwicklung, Struktur und staatspolitische Zielsetzung [The People's Conservatives 1928-1933, Development, Structure, and political Aims] (Duesseldorf: Droste, 1965): 23-78

227 The ideological differences between People's Conservatives and the Nazis, Jonas, Die Volkskonservativen, 915, the support of Schleicher, 127-129; Bracher, Aufloesung, 322

${ }^{228}$ Winkler, Weimar, 526

${ }^{229}$ Axel Schildt, "Die Illusion der konservativen Alternative" [The Illusion of a conservative Alternative], in: Schmaedeke, Widerstand, 151-168; Speech of Simpfendoerfer, in: Verhandlungen des Reichstags, Vol. 457, 2. Session (March 23, 1933): 38 (D)

230 Schleicher's statement to Puender, Oct. 8, 1932, see the diary of Hermann Puender, Politik in der Reichskanzlei, Aufzeichnungen aus den Jahren 1929-1932 [Politics in the Reichskanzlei, Recordings between 1929 and 1932], ed. Thilo Vogelsang (Berlin: Walter de Gruyter, 1961): 149

231 Thilo Vogelsang, "Zur Politik Schleichers gegenueber der NSDAP 1932" [Schleicher's Politics towards the NSDAP 1932], in: Vierteljahrshefte fuer Zeitgeschichte 6, no. 1 (1958): 86-116, 87-90 
July of 1932 as the 'final' answer, and therefore was unable to offer Hitler during the next six months anything more than a few cabinet positions and the job of Vice-Chancellor. Because of these restrictions, he could only hope getting the Nazis involved as the junior coalition partner without the crucial Chancellorship, something he seemed to believe in until January 30, 1933, when Hindenburg proved him wrong and finally appointed Hitler. ${ }^{232}$ Even Wilhelm, when Schleicher became Chancler in December 1932, had its doubts about its validity and later confessed (in March 1933) to General Ferdinand von Bredow, one of Schleichers friends and assistants that he wanted to give the Chancellorship rather to Hitler:

"We all regret that Schleicher has allowed himself to be manoeurved into this pathetic position and it is a truism when I say that I had urgently warned him of accepting the Chancellorship, because it was foir me personally clear that after the Papen Government resigned, there was only one solution: to give Adolf Hitler the Chancellorship. (...) Now we have to support the unity of this government in every way and to smash everyone's face who tries to bring disquiet and distrust against it."233

In short, Schleicher and the Crown Prince are not candidates with any credibility for being protagonists of preventing Hitler from coming to power or were a real alternative to the Nazis. Otherwise, Wilhelm, as we have demonstrated, would not have supported the new regime, and Schleicher would not have gone out of his way to confirm that he was a supporter of the Nazis before 1933, when he did not have to. Regarding the transfer of power to the NS-party, Pyta/Orth are continuing to speculate that the Crown Prince's public statements did not reflect his inner convictions because his reaction to the 'Marburg Speech' of Franz von Papen on June 17, 1934 (Wilhelm is supposed to have congratulated Papen and the author of the speech, Edgar J. Jung ${ }^{234}$ ) should demonstrate that the Crown Prince was a "passive carrier of knowledge" who would act behind the scenes in "conservative opposition networks", asserting that Wilhelm knew certain people in Papen's Vice Chancellor's office, that were privy to an alleged plan to overthrow Hitler. ${ }^{235}$ In addition, Pyta/Orth point out the fact that three collaborators of the Crown Prince were arrested during the days of the Roehm-affair ${ }^{236}$,

\footnotetext{
${ }^{232}$ Vogelsang, "Politik Schleichers", 90

${ }^{233}$ Urbach, Useful Idiots, 541

${ }^{234}$ Pyta/Orth, Report, 98, point out that the Crown Prince sent letters to Papen and Jung is based on the memory of his sister, Viktoria Luise, and the adjutant of the former Kaiser, v. Ilsemann; the original letters by itself seem to be lost

235 Pyta/Orth, Report, 98-99

${ }^{236}$ Hermann Mau, "Die "Zweite Revolution": Der 30. Juni 1934” [The second Revolution, June 30, 1934], Vierteljahrshefte für Zeitgeschichte 1, no. 1 (1953): 119-137; Klaus-Juergen Mueller, "Reichswehr und »Röhm-
} 
which they see as another that the Crown Prince should be located close to the opposition and that his public statements, where he supported the propaganda of the regime cannot be taken as honest expressions of his real convictions. Their assertions read like a reversal of the usually negative principle 'guilty by association' turned positive. They conclude, Wilhelm knew people who were against Hitler and therefore, he was part of the conservative 'opposition'. This conclusion is not only absurd but simply incorrect.

It is no surprise that Papen's Marburg Speech (written by Edgar Jung) contains lots of ambiguities (instead of being in 'opposition' to the regime) and was more focused to call an end to Roehm 's alleged 'second revolution', than to call for a restoration of basic rights for all the people, specifically those who were suffering in concentration camps. The speech was on the one hand a confirmation of Hitler's policies that took the common goals for granted, while on the other hand Papen criticized methods and procedures of the Nazi seizure of power. ${ }^{237}$ Neither did he admit his own role in the transfer of power to the NS-movement nor did he state any criticism towards Hitler and the actions of the Nazis against its political opponents or the Jews. In a telegram to Hitler right after the speech, Papen explicitly stated, "in the old university town of Marburg I have just struck a blade for the unwavering and undistorted continuation of your revolution and the fulfillment of your word." ${ }^{238}$ In other words, Papen just tried to get a little 'pregnant'with critiscm, which - as we all know - does not work.

In a way the speech initiated an unexpected and unintended call to $\operatorname{arms}^{239}$ for Hitler who was interested in eliminating any opposition to his regime, conservative or revolutionary. Jung as a National Conservative with strong convictions towards a religious renewal of the German Volksgemeinschaft, saw in Hitler's sole claim to power the National Conservatives and its intellectual base (like himself) marginalized $^{240}$ and therefore was hoping to start a

Afläre«, aus den Akten des Wehrkreiskommandos (Bayer.) VII" [Reichswehr and the 'Roehm-Affair, from the Files of Wehrkreiskommando VII], in: Militaergeschichtliche Mitteilungen 3 (1968): 107-144; "Hitler in warning reveals Movement for $2^{\text {nd }}$ Revolution", New York Times, July 3, 1934, 1

237 Reiner Moeckelmann, Franz von Papen, Hitlers ewiger Vasall [Franz v. Papen, Hitlers eternal Vassal] (Darmstadt: Philipp von Zabern, 2016): 247-255

${ }^{238}$ Ullrich, Hitler I, 514

239 Rainer Orth, “Der Amtssitz der Opposition”? Politik und Staatsumbaupläne im Büro des Stellvertreters des Reichskanzlers in den Jahren 1933-1934 [The official seat of the opposition? Politics and state restructuring plans in the office of the Deputy Chancellor from 1933-1934] (Koeln: Boehlau, 2016): 533-534; reviewed by Larry Jones, Central European History 50, no. 3 (2017): 285-286; and Bjoern Hofmeister, Neue Politische Literatur 64 (2018): 303-305

${ }^{240}$ Rosnan Magub, Edgar Julius Jung, right-wing enemy of the Nazis: a political biography (Rochester, N. Y.: Camden House, 2017): 191-226; Sebastian Maass, Die andere deutsche Revolution: Edgar Julius Jung und die metaphysischen Grundlagen der Konservativen Revolution [The other German Revolution, E. J. Jung and the metaphysical Basis of a Conservative Revolution] (Kiel: Regin-Verlag, 2009): 119-126, in the original 'Marburg 
'conservative' revolution against the Nazis that was determined to restore 'decency' and 'good will' but not the 'basic rights' for all people. ${ }^{241}$ Jung, who was originally in favor of the transfer of power to the Nazis on January 30, 1933, is famous for having said afterwards that they were responsible for putting Hitler into power and now needed to get rid of him. ${ }^{242}$

The initial conservative opposition in the 'Vice-Chancellery' in 1934 was banking on Hindenburg and the Reichswehr ${ }^{243}$ and their specific 'plan' (unlike the one in 1944), was based purely on the 'hope' that Hindenburg - in connection with Papen's Marburg speech would initiate a strike against Hitler through the Reichswehr and replace him with a 'directorate' of politicians that included - aside from Hitler, Goering, Goerdeler, Bruening and Papen ${ }^{244}$ - to turn the one-person dictatorship into a multi-person directorate that was an illusion from the start. As Tschirschky has stated in his memoirs ${ }^{245}$, they did not want to remove the Fuehrer, they just wanted to coopt him and still use his 'services', although not as sole dictator of the Reich. And that at a time when the Reichswehr generals were miles away from considering a serious putsch against Hitler (as if they were ever serious about it) and more concerned about eliminating the competitive threat of the SA.

Hitler took the opportunity of the 'Roehm-affair' to take action against the SA in order to confirm the two-pillar concept (party and $a r m y^{246}$ ) that would not allow a third pillar and a competitor for the Reichswehr, reaffirming what he had promised Hindenburg previously, that

speech', 135-149; Papen is making the point that the national-conservative revolution basically differs from the Nazis in 'tactics' and is condemning the attempts of the SA for a second revolution; Larry E. Jones, "Edgar Julius Jung: The Conservative Revolution in Theory and Practice", Central European History 21, no. 1 (1988): 142-174, is sceptical regarding Jung's sense of practicality, 174: “As it was, Jung's political program had a curiously anachronistic quality to it that effectively militated against its translation into practice."

${ }^{241}$ Werner E. Braatz, "Two Neo-Conservative Myths in Germany 1919-32, the 'Third Reich' and the 'New State",, in: Journal of the History of Ideas 32, no. 4 (1971): 569-584, 584: "The neo-conservatives had failed to find a third way between parliamentary democracy and totalitarian dictatorship. Indeed, by destroying the institutional framework of the democratic republic, they had paved the way for an age of caesarism under the sway of a single party - the Nazis."

${ }^{242}$ Jung's statement about their responsibility, Heinz Hoehne, "Mordsache Roehm III" [The Murder Case of Roehm, Part III], in: Der Spiegel 25 (1984): 128-142, 137

243 Regarding the 'plans' of the oposition, Guenther von Tschirschky, Erinnerungen eines Hochverraeters [Memoirs of a Traitor] (Stuttgart: DVA, 1972), 154-180; Orth, Amtssitz, 451-518

${ }^{244}$ Tschirschky, Erinnerungen, 154-163, 172-179; Orth, Amtssitz, 519-530, 527, states that the "action plan" failed, because the 'opposition' group during the crucial days after June 17, 1934, could not get Papen to go see Hindenburg to initiate the chain of events that was supposed to cause the demise of the regime

245 Tschirschky, Erinnerungen, 176-178

246 Kirstin A. Schaefer, Werner von Blomberg, Hitlers erster Feldmarschall [Hitler's first Field Marshal] (Paderborn: Schoeningh, 2006): 133-145 
the army was supposed to be left out of any domestic quarrels. ${ }^{247}$ At the same time taking action against the SA secured him a non-veto of the Reichswehr leadership regarding the succession of Hindenburg ${ }^{248}$ as the prize to acquire absolute power. Hitler had the advantage of a powerful ally that would cover his action against Roehm, that came out of an identity of interests which was widely perceived as a necessary preemption of a common foe. ${ }^{249}$

Papen's 'criticism' contained in the Marburg speech regarding the shortcomings of National Socialism after the legal abolition of all basic rights was nothing more than an appeal to the good-will of the Nazis laced with a self-limitation that any criticism was only allowed for those people who had "proven their loyalty" to the Fuehrer with the assurance of the speaker that their intention was not to go back to the "liberal ideas of truth and freedom". ${ }^{250}$ Without that and any support of President Hindenburg or the Reichswehr, Papen's criticism was a futile exercise without any practical consequences. The whole Marburg speech is by itself contradictory, and, even at the time, could not be taken as a serious attempt of resistance. Papen criticized the methods of the Nazi-rule but not the rule by itself of which he was also a supporter and an active member. No wonder that this whole incident is not even mentioned by the classical accounts of the history of the resistance against Hitler. ${ }^{251}$

Aside of the role of the Crown Prince, there was always a strong focus on the conservative opposition to Hitler, because they - through the command of the Reichswehr - had the means to remove the Fuehrer and the NS-movement from power. ${ }^{252}$ But the conservative elites had

\footnotetext{
${ }^{247}$ Klaus- Juergen Mueller, Das Heer und Hitler, Armee und nationalsozialistisches Regime, 1933-1940 [The Army and Hitler, Army and national socialistic Regime] (Stuttgart: DVA, 1969): 35-141; the restoration of 'decency' was reported by Harold C. Deutsch as a goal of Carl Goerdeler, "Diskussion zur Geschichte des Widerstandes, ein Tagungsresuemee" [Discussion regarding the History of Resistance, Conclusions of a Conference], in: Schmaedeke, Widerstand, 1119-1158, 1126-1127

${ }^{248}$ Hoehne, "Mordsache Roehm III", 139: "The SA remained an obstacle on his way to sole rule, because without a disempowerment of the army of brown shirts, the generals of the Reichswehr would not leave it up to Hitler to succeed Hindenburg".

${ }^{249}$ Regarding the so-called 'Roehm-Putsch' as it was euphemistically labeled by the Nazis, Eleanor Hancock, "The Purge of the SA Reconsidered: "An Old Putschist Trick", Central European History 44, no. 4 (2011): 669683; David Jablonsky, "Roehm and Hitler: The Continuity of Political-Military Discord", Journal of Contemporary History 23, no. 3 (1988): 367-386

${ }^{250}$ Maass, Revolution, 135, 137

251 Peter Hoffman, The History of the German Resistance, 1933-1945 (Cambridge: MIT Press, 1977); Schmaedeke, Widerstand, contains no entry describing Papen's Vice chancellery as a center of the 'opposition' to Hitler, and is only mentioned by Schildt, “Konservative Alternative”, 163, as a 'special aspiration' of Papen and others for a 'catholic-fascistic' regime

${ }^{252}$ Leonidas Hill, "Towards a New History of German Resistance to Hitler", Central European History 14, no. 3 (1981): 369-399 is proposing a new history of the resistance to overcome the main focus on the National Conservatives
} 
to overcome a structural dilemma: they all had welcomed the Nazis coming to power ${ }^{253}$ (with few exceptions) and had agreed - domestically as well as internationally - to the overall goals of Hitler and the NS-movement reaffirming a 'basic consensus' ${ }^{254}$ between the conservatives and the NS-party. Initially, when Hitler was acting carefully in the foreign policy arena, the leaders of the Reichswehr as the second pillar of the state and the Foreign Office through Minister von Neurath ${ }^{255}$, were pushing ahead demanding Germany's exit from the United Nations and the disarmament conference ${ }^{256}$ to accelerate the path of rearmament, while the Crown Prince lent his public support. ${ }^{257}$ As Hitler stuck to the strategy of Selbstverharmlosung (making oneself appear as harmless as possible), gaining ground in the international arena without firing a shot, his prestige in Germany grew by the day and the National Conservative elites played along and facilitated - as a functional elite who was fighting for influence and status ${ }^{258}$ - Germany's rearmament as part of the 'basic consensus'.

They also did not protest when Hitler revealed his 'extended' goals in November 1937, that went way beyond the revision the Versailles system to regain the 'lost' territories. ${ }^{259}$ The National Conservatives were only worried about one thing: avoiding and preventing a major war (in reminiscence of 1914) with the Western Powers, before Germany was prepared and would be able to fight successfully. As a few people had already warned in 1933-34, despite its talk of peace, the NS-Government was preparing for war to recover Germany's great

\footnotetext{
${ }^{253}$ Theodore S. Hamerow, On the Road to the Wolf's Lair. German Resistance to Hitler (Cambridge, MA: Cambridge University Press, 1997): 19-34, 83-114; Hans Christoph Kraus, "Der konservative Widerstand gegen den Nationalsozialismus" [The conservative Resistance to National Socialism], in: Politischer Widerstand, allgemeine theoretische Grundlagen und praktische Erscheinungsformen in Nationalsozialismus und Kommunismus, ed. Barbara Zehnpfenning (Baden-Baden: Nomos, 2017): 181-204, 185-189, is basically denying Hamerow's findings trying to exculpate National Conservatives in pointing to a few 'resisters' like Kleist-Schemnzin, Edgar Jung and the 'resistance' in 1933-34 and is also praising Papen's Marburg speech
}

${ }^{254}$ For the 'basic sonsensus', Klaus-Juergen Mueller, "Militaerische Elite”, 289

${ }^{255}$ Regarding the goal of Foreign Minister von Neurath for Germany to leave the Voelkerbund, Hans Juergen Doescher, SS und Auswaertiges Amt im Dritten Reich [SS and Foreign Office in the Third Reich] (Frankfurt/M.: Ullstein, 1991): 62-63; Doescher is showing that Neurath was one of those National Conservatives who even before 1933 became a supporter of Hitler and afterwards, and stayed on - as he pointed out to a colleague - "um Schlimmeres zu verhueten" [to prevent worse], 66

${ }^{256}$ Mueller, "Deutsche Militaerelite", 260-263

257 The Crown Prince published two articles in support of the referendum of the Hitler administration to leave the Voelkerbund and elect a new Reichstag completely with NS-candidates, Ullrich, Hitler I, 538-539; Clark, Report, 5-6, 8-9; Malinowski, Report, 34

${ }^{258}$ Doescher, SS und Auswaertiges Amt, 71, 114-118, is pointing out that in 1937 many diplomats considered to become members of the SS that the personal administration of SS talked about a Massenflucht (mass flight)

${ }^{259}$ Mueller, "Deutsche Militaer-Elite", 274-275, 280 
power status, drawing conclusions from the rearmament policies of the new regime. ${ }^{260}$ The military leadership knew too well that their rearmament program in 1938 was still incomplete and preferred to wait than to provoke a major war with France and Great Britain, remembering the problems of the First World War, when Germany did not seem to be prepared for an extended fight. ${ }^{261}$

The conservative elites in the Foreign Office and the newly expanded Wehrmacht were all in favor of a Grossdeutschland ${ }^{262}$ (Larger Germany), but disagreed again (like in domestic politics) with the Nazis over the methods how to achieve it. They shunned the risk of an 'underprepared' war, while Hitler was constantly urging them to be bold and reminded them of the need to overcome the usual resistance to his plans (like in the case of Austria, Czechoslovakia, Poland etc.), and projected (correctly) that the Western Powers would not intervene. When war was avoided in 1938 through the Munich Treaty and Czechoslovakia ceased the area of Sudetenland to Germany, the military opposition to Hitler was devastated, because their focus of preventing a war with the West was neutralized (while Hitler was temporarily celebrated as the angel of peace) and postponed to 1939, when Hitler was ready to attack Poland. But even at this point the military opposition was wavering and procrastinating, knowing too well that the elimination of Poland was also part of the 'basic consensus' for a Grossdeutschland that was necessary for achieving hegemony in Europe. ${ }^{263}$

As Klaus-Juergen Mueller has put it, the reaction of the military opposition indicated a mixture of "submissiveness, resignation, fatalism and illusions." The decisive factor for their behavior was not opposition but a basic consensus about the foreign policy goals they shared with Hitler: "The reach for European hegemony, even for world power of the German Reich and the extensive militarization of the nation in the age of the 'technical-industrial war' were the main elements (...) that linked them to Hitler, making them support his system and affirm his war policy". ${ }^{264}$ To compensate for the defeat in 1918, the Reichswehr generals looked

\footnotetext{
${ }^{260}$ Fredrick L. Schuman, "The Third Reich's Road to War", Annals of the American Academy of Political and Social Science 175 (September 1934): 33-43; Frederick L. Schuman, "Nazi Dreams of World Power", Current History 39 (1934): 535-541; Frederick Birchall, "Reich is thinking of War despite its talk of Peace", New York Times, October 8, 1933

${ }^{261}$ Mueller, "Deutsche Militaer-Elite", 282-283

${ }^{262}$ Bernd-Juergen Wendt, Grossdeutschland. Aussenpolitik und Kriegsvorbereitung des Hitler-Regimes [Larger Germany, Foreign Policy and War Preparation of Hitler's Regime] (Muenchen: Dtv, 1987): 7-37

${ }^{263}$ Klaus-Juergen Mueller, “Zu Struktur und Eigenart der nationalkonservativen Opposition”, 338-339

${ }^{264}$ Mueller, "Deutsche Militaer-Elite”, 288-289
} 
back on almost twenty years of planning for a war of revenge ${ }^{265}$ against the Western Powers, while during the years of the republic it was based on pure illusions and only Hitler after 1933 had given them the means to fulfill this desire. In short, for $99 \%$ of all National Conservatives, Hitler and the NS-movement became the realization and implementation of their dreams to wipe out the notch of defeat in $1918 .^{266}$

Therefore, it is no surprise, when Hitler in 1939 and 1940 successfully initiated the invasions of Poland, France, Belgium, Holland, Danmark and Norway, being at the height of his popularity, and having proven wrong the dire predictions of the military leadership, that nobody from the Conservatives - at that time - even remotely thought about resisting or removing him. ${ }^{267}$ They were rather of the mindset - like the Crown Prince - to send Hitler telegrams of congratulations. The National Conservatives were determined - out of a false patriotism - to differentiate between the war and its territorial gains they deemed legitimate and the politics of the Nazis who were the real beneficiaries of reestablishing Germany's hegemony in Europe. As long as Hitler was successful, he had nothing to fear from the conservative opposition that disintegrated until his first defeats in the Soviet Union. In short, the opposition wanted to keep Hitler's territorial gains but did not want him and the Nazi administration because they were appalled by his methods and the level of corruption in higher circles. ${ }^{268}$

Even a year later when Hitler conceived the attack on the Soviet Union and asked the military leadership to work out his instructions to conduct a war of annihilation the generals of the Wehrmacht went along and delivered. As Mueller has put it, "The politically disempowered military elite saw in this war both the resumption of Eastern political and strategic military concepts from the time of the First World War as well as an ideological and socio-political extermination struggle against an enemy that had already been seen behind the great challenge of the revolution of 1918."269 They should have known better considering the experience with

\footnotetext{
${ }^{265}$ Cark Dirks, Karl-Heinz Jansen, Der Krieg der Generaele, Hitler als Werkzeug der Wehrmacht [War of the Generals, Hitler as a Tool of the Army] (Berlin: Propylaen, 1999): 11-33, Doc. 1, "Gedanken ueber den Krieg der Zukunft" [Thoughts about the War of the Future], 192-209

${ }^{266}$ Mueller, "Deutsche Militaer-Elite", 240-247

${ }^{267}$ Ueberschaer, "Militaeropposition", 345-367, 348-350

${ }^{268}$ Hamerow, Wolf's lair, 289

${ }^{269}$ Mueller, "Deutsche Militaer-Elite”, 289
} 
the SS-Einsatzgruppen ${ }^{270}$ in Poland two years earlier, but they still played along and executed Hitler's war of annihilation creating a cover for the Holocaust that made them criminal accomplices of the Nazis. Objections by generals, who thought that the SS went too far who had already protested in 1939 over its actions in Poland, were brushed away by the military leadership who seemed only interested in getting the war successfully executed. ${ }^{271}$

Also, it is not far-fetched to state, that in the minds of Stauffenberg, Tresckow, and others, who had a rather gloomy outlook before starting the putsch in 1944 expecting failure, the assassination of Hitler became the moral substitute as a "form of individual and collective atonement, expiation, regeneration and redemption" for their earlier support of the regime. ${ }^{272}$ In short, the ambivalence of the conservative opposition can be summarized as follows: until July 20, 1944 they found all the reasons not to act, rather than reasons to take effective action that included the end of the Fuehrer and his regime. Before they finally decided to act, they could justify the putsch only for moral reasons, considering that they had realized it was too late to expect the Allies to negotiate on a different outcome than unconditional surrender.

The overall behavior of the Crown Prince confirms that a majority of German people and the elites, for the 'benefit' of Germany, would have avoided an attack on Hitler letting him fulfill his mission although a catastrophic ending was foreseeable. When Wilhelm and his son, Louis Ferdinand, had a real chance to join the assassination attempt on Hitler in 1944, the Crown Prince basically told him not do it and refused any participation by himself, thwarting the last chance to show that there was a royal opposition that had the courage to stand up for its beliefs. $^{273}$

\section{Final Considerations}

As we have seen in our discussion of the seven topics, the reports in favor of the Hohenzollern show multiple deficiencies, allowing their authors to conclude that the Crown

\footnotetext{
270 War, Pacification and Mass Murder, 1939. The Einsatzgruppen in Poland, ed. Juergen Matthaeus, Jochen Boehler, Klaus-Michael Mallmann (Lanham, Md.: Rowman \& Littlefield, 2014); Helmut Krausnick, Hitlers Einsatzgruppen. Die Truppen des Weltanschauungskrieges 1938-1942 (Frankfurt/M.: Fischer, 1985)

${ }^{271}$ Johannes Hürter, Felix Römer, "Alte und neue Geschichtsbilder von Widerstand und Ostkrieg, Zu Hermann Gramls Beitrag 'Massenmord und Militäropposition'" [Old and new historical images of resistance and the Eastern War. On Hermann Graml's contribution 'Mass murder and military opposition'], Vierteljahrshafte fuer Zeitgeschichte 54, no. 2 (2006): 300-322

${ }^{272}$ Hamerow, Wolf's Lair, 350

${ }^{273}$ Jonas, Kronprinz, 270-276; F. W. v. Preussen, Hohenzollern, 268-290
} 
Prince did not support the activities of the Nazis, and was working against them rising to power in 1933. What makes these reports deficient is not only the lack of historical context: It is their attempt to create a broad gulf between the National Conservatives and the Nazis that cannot explain the alliance that lasted way beyond 1933. They construe a conflict between them, instead of pointing towards their common goals which had originally made the alliance possible. ${ }^{274}$ The alliance was all about that the German Reich being able to regain its former military strength to turn those efforts into sizable gains, as Hitler tried to do from the beginning.

The two groups only became adversarial after 1933 about the methods of the Nazis when the conservative partner realized that one of their shared goals, to abolish political pluralism, was backfiring and could turn against them, and that they afterwards were at the mercy of the Nazis. Hitler, remembering the domestic divisions during the First World War, not only followed an ideology that abhorred any public dissent or criticism, but he specifically was averse to any public pluralism, projecting a future war that required perseverance and staying power and not open criticism that probably reminded him of the 'stab-in-the-back legend' in 1918. Only a small minority of the conservatives foresaw this dilemma and alerted their colleagues, but the majority refused to listen and agreed to accept an enabling act that ended the multi-party system and was replaced with the dictatorship of the Nazis.

The role of the National Conservatives, who had agreed to form a coalition with the Nazis voluntarily, preferring to ignore any warnings at the time, was that of a junior partner, that Hitler needed as a functional facilitator to carry out his orders, but not as political partner with a voice trying to intervene and 'soften' his 'methods'. The two reports in favor of the Hohenzollern avoid discussing this along with the shared goals between the two parties that are crucial for understanding the Crown Prince and his political circles between 1930-1932, and his behavior after January 30, 1933. Without looking at these issues, Wilhelm's support for National Socialism is without any rationale and cannot be explained except through simple opportunism, based on his assumed 'naivete' or the subjective 'likability' of Hitler.

Both reports in favor of the Hohenzollern display the revisionist tendencies that after 1945 were expressed to exculpate those National Conservatives, like Hindenburg, Papen, Schleicher, Schacht, Neurath, Hugenberg, the Crown Prince and others, who are responsible for the transfer of power to the Nazis, now claiming a Zwangslage ('predicament') that

\footnotetext{
${ }^{274}$ Machtan, Kronprinz, 243, seems surprised about the 'convergence' of their interest in the common takeover of power to eliminate the Weimar Republic
} 
allegedly was based on the "compulsion of necessity". ${ }^{275}$ In our case, revisionist accounts of what happened between 1930 and 1945, appeared specifically in the 1950s and 1960s, when conservative survivors like Papen, Schacht, Meissner, Weizsaecker and others published their memoirs and tried to distort the record by downplaying their own roles asserting that they were against the Nazis from the start (and did not like them), but stayed on to prevent the 'worst'. And when the worst happened and they were a part of it, they shrugged their shoulders and claimed a Zwangslage and that they were basically 'powerless' to do anything against it. ${ }^{276}$ In a nutshell, their were prepared against any criticism and defended their participation with the Nazis through predicaments they have brought onto themselves.

For the fact that the Crown Prince has 'significantly advanced' Hitler and the Nazis he himself is the best witness: Machtan has discovered a document in the Federal Archive in Koblenz where Wilhelm sent a letter to Hitler (and Viktoria von Dirksen, a confidante of Hitler) on August 15, 1936 where he summarized his activities in favor of the Nazis, signaling Hitler, that he has been a staunch supporter and doesn't deserve the current isolation and dismissal, the way he has been treated since a couple of years, just because - we have to add he wanted to restore the monarchy of the Hohenzollern and turn Hitler's sole dictatorship into a 'directorate', where the National Conservatives still had a say. Wilhelm's letter is a confirmation of his crucial support and at the same time a complaint like 'nothing is so hard as man's ingratitude', a letter, that was never sent, because - as Machtan points out - the Crown Prince, despite being furious, feared a rupture with Hitler, that needed to be avoided at all cost, considering that they - on the other hand - agreed on $90 \%$ of the issues. Wilhelm summed up his support for the Nazis as follows:

\footnotetext{
275 Hubatsch, Hindenburg, 1, is defending the President for his decision to appoint Hitler and is stating that criticism of this decision was made, "without the reasons for these decisions, the general timing, and that the compulsion of necessity was being duly taken into account."

276 A selection of these memoirs and its reviews that tried to correct the omissions and distortions, Franz v. Papen, Memoirs (London: Deutsch, 1952); Franz v. Papen, Der Wahrheit eine Gasse (Muenchen: List, 1952); reviewed by Werner Conze, "Papens Memoiren", Historische Zeitschrift 175, no. 2 (1953): 307-317; Moeckelmann, Franz v. Papen; Hjalmar Schacht, 76 Jahre meines Lebens (Bad Woerishofen, Kindler \& Schiemeyer, 1953), reviewed by Fritz Neumark, "Hjalmar Schacht. Leben und Wirken einer umstrittenen Persönlichkeit", Finanz-Archiv 38 (1980) 478-485; Lutz Graf Schwerin v. Krosigk, Memoiren (Stuttgart: Seewald, 1977); reviewed by Peter C. Witt, "Memoiren", Historische Zeitschrift 227 (1978): 727-728; Otto Meissner, Staatssekretaer bei Ebert, Hindenburg, Hitler: der Schicksalsweg des deutschen Volkes von 1918 1945, wie ich ihn erlebte [State Secretary with Ebert, Hindenbirg and Hitler] (Hamburg: Hoffmann \& Campe, 1950); the review "In einem Hemd", Der Spiegel, November 22, 1950, 11-12, drew the conclusion that Meissner's memoirs is a 'justification for all those who stayed on to prevent a situation which might become worse'; Ernst von Weizsaecker, Erinnerungen (Muenchen: List, 1950); Peter de Mendelssohn, “Die verhinderten Hochverraeter. Wege und Irrwege neuerer deutscher Memoirenliteratur"[The Traitors who prevented themselves, Ways and Aberrations of recent German memoir literature], Der Monat 4 (1951), 495-509
} 
"Long before the National Socialist movement took hold of the majority of the people, I exchanged personal thoughts with you and stood up for you and your movement with a warm heart. Since the seizure of power I held back for understandable reasons and only thought of how I could help to rebuild the German people. I have spoken and written for you and your big ideas, wherever I was given the opportunity to do so. I also used my very extensive international connections wherever possible, for the work you serve."277

Machtan concludes: "The monstrous as well as definitive reality of National Socialism and its masterminds does not seem to have reached him even three years after Hitler came to power." In Wilhelms mind, "the rulers would only have to recognize just once how deeply he feels connected to them." ${ }^{278}$ That sums up the relationship the Crown Prince had with the Nazis, which has been confirmed solidly by many documents and will be confirmed in the future.

As Karina Urbach has stated, the science of history owes an incredible amount of gratitude to the person who leaked the four reports to the public ${ }^{279}$, so that everybody finally had the chance to discuss its content. She also indicates that the Crown Prince, "who went to bed with every adversary of the Weimar Republic", decided to rather work with Hitler than Schleicher, because the latter was not strong enough to fulfill the task ahead. Wilhelm's temporary cooperation with Schleicher forwarding certain information to him about the inner discussions of the Nazi party was short lived and does not help to exculpate him. He - as an opportunist was merely keeping his options open and finally went with the stronger battalions of the Nazis. 280

Considering the situation in the early 1930s in Germany, it is difficult to overlook several opportunities for the decision-makers of the Weimar Republic to fight Hitler and prevent him

${ }^{277}$ Machtan, Kronprinz, 234, German original: "Lange bevor die nationalsozialistische Bewegung die Mehrheit des Volkes erfasste, stand ich mit Ihnen in persoenlichem Gedanken austausch und setzte mich fuer Sie und hre Bewegung mit warmen Herzen ein. Seit der Machtergreifung hielt ich mich aus begreiflichen Gruenden zurueck und dachte nur daran, wie ich am Aufbauwerk des Deutsche Volkes mithelfen koennte. Ich bin in Wort und Schrift fuer sie und Ihre grossen Ideen eingetreten, wo mir dazu nur irgendwie Gelegenheit gegeben wurde. Auch meine sehr weitgehenden Beziehungen zum Ausland setzte ich, wo es nur moeglich war, fuer das Werk, dem sie dienen, ein."; Wilhelm tried to get back in Hitler's 'good book' in using his secretary to send numerous documents of support to Viktoria von Dirksen, a confidant of the Fuehrer, in order to become a public personality again, that would fuerther advance the 'German cause' (p. 236)

${ }^{278}$ Machtan, Kronprinz, 237

${ }^{279}$ The reports were leaked by the comedian Jan Boehmermann in his late-night show 'Neo Maganzin Royale' of the Second German Public TV channel on November 14, 2019, Joerg Haentzschel, "Jan Boehmermann, der Aufklaerer", Sueddeutsche Zeitung, November 15, 2019

${ }^{280}$ Eva-Maria Schnurr, "Der Kronprinz ging mit jedem Gegner der Weimarer Republik ins Bett”, Interview mit Karina Urbach, Spiegel.de, November 26, 2019; Karina Urbach, Hitler's heimliche Helfer, der Adel im Dienst der Macht [Hitler's secret Helpers, the Nobility in service of Power] (Darmstadt: Theiss, 2016): 212-215, 301, 313 
from coming to power if they wanted to. One of these chances occurred in 1930, when the Prussian Government and even that of the Reich compiled reports that clearly demonstrated the dangerous goals and methods of the NS-movement. The reports were clearly pointing out that the NS-party was categorically hostile towards the democratic system and planned to do everything in their power to eliminate the republic and establish instead a dictatorship of their own. The 'threat of civil war' by the SA and similar groups ${ }^{281}$, that hung over the republic from the beginning, deserved a serious answer which excluded 'cuddling' and endless 'negotiations' that send the wrong message. A prime opportunity to prevent the growth of the NS-movement was missed in the early 1930s while the political elites did nothing to prevent a foreseeable disaster.

There were several chances to send a clear message to the NS-movement and its voters and prevent them from coming to power, even in November of 1932, when it became clear that the Nazis were already in decline at the voting booth. If the party would have been made illegal earlier, they could not have participated in elections and they were only left to initiate another coup d'etat. If they had to challenge the 'system' in a direct fashion, that would have forced the Reichswehr to fight them determining the outcome as a loss to the NS-movement. Either way, if Hindenburg would have stuck to conservative values and would have not appointed Hitler as Chancellor, the NS-movement, shut out from any power participation, either had the option of falling apart or had to try a putsch like in 1923.

A good example for a successful resistance - domestically as well as internationally - is the case of Austria, a German speaking country, between 1933 and 1938. Despite a lot of pressure by the Nazis from Germany, the conservative Government of Engelbert Dollfuss, although it took an authoritarian turn in March of $1933^{282}$, defied all the Nazi attempts of blackmail and terrorism, economic boycott and invasion threats, which led to a ban of the NS-party in Austria. As a result, the Nazi party was denied a 'legal' path to power and had to facilitate a putsch in July $1934^{283}$ that ended in defeat, although Chancellor Dollfuss got killed and the whole affair invoked reminiscences to Hitler's failed putsch in Germany in 1923. In short, the National Conservatives in Austria in 1932-33 - compared to Germany - were not fooled by

\footnotetext{
${ }^{281}$ Winkler, Weimar, 477

${ }^{282}$ Gottfried-Karl Kindermann, "Zur neuen Selbstfindung Oesterreichs durch Geschichtskrisen und Widerstand, unter besonderer Berücksichtigung der Österreich-Ideologie der Dreißiger Jahre" [On the new self-discovery of Austria through historical Crises and Resistance, with special Consideration of the Austrian Ideology of the thirties], Zeitschrift für Politik 32, no. 2 (1985): 279-295, 289-291

${ }^{283}$ Kurt Bauer, "Hitler und der Juli-Putsch 1934 in Oesterreich" [Hitler and the July-Putsch in Austria in 1934], Vierteljahrshefte fuer Zeitgeschichte 59, no. 2 (2011): 193-227
} 
the Nazis and their demand for 'new' elections was refused, and, resisting all other threats to transfer power to them.

The Austrians withstood the Nazi menace for another five years, and only transferred power to them in $1938^{284}$ after heavy pressure from Hitler, the final invasion by the Wehrmacht and no international support or help that could have prevented the Anschluss (connection) of Austria, a contemporary euphemism, and isolated the Nazis. The reasons for the resistance in Austria compared to its non-existence in Germany seems obvious: the Austrian Conservatives did not share any goals with the Nazis and had everything to lose if the NS-movement also took over power in Austria, considering that $78 \%$ of the seats in the Nationalrat (Parliament) were in the hands of non NS-parties. ${ }^{285}$ In Germany the Nazis were completely unprepared ${ }^{286}$, could not believe themselves when they finally took over in 1933 and Goebbels confirmed in his diary their determination never to surrender power to anybody, predicting the end of the NS-movement as it happened in 1945: "We will never give up power again, only if somebody will carry us out as corpses." 287

The Crown Prince - even before 1914 - was a champion of authoritarian solutions, a spokesperson for right-wing radical fanatics, that suggested a coup d'etat to remove the Chancellor Bethmann-Hollweg and the Foreign Secretary Jagow and demanded a war on the "Jewish intrigues and the incitements of Social Democratic leaders" that were supposedly "corrupting the monarchical spirit of the German people" at home and a war against France and Russia abroad. Wilhelm supported a memorandum by a General, who wanted to abolish universal suffrage for the Reichstag by the means of a putsch or a 'successful war' and demanded draconian measures to 'solve' the 'Jewish question' through higher taxation, exclusion form state administration and journalism and preventing 'miscegenation' between the 'Jewish and Germanic races' ${ }^{288}$, measures that were finally enacted by the Nazis starting

\footnotetext{
284 Norbert Schausberger, "Oesterreich und die nationalsozialistische Aussenpolitik" [Austria and National Socialistic Foreign Policy], in: Hitler, Deutschland und die Maechte, Materialien zur Aussenpolitik des Dritten Reichs, ed. Manfred Funke (Duesseldorf, 1978): 728-756, 744-748

${ }^{285}$ Gottfried-Karl Kindermann, Oesterreich gegen Hitler, Europas erste Abwehrfront 1933-1938 [Austria against Hitler, Europe's first Front of Resistance, 1933-38] (Muenchen: Langen Mueller, 2003): 40-125, 341-351

286 Hans Mommsen, "Ausnahmezustand als Herrschaftstechnik des NS-Regimes" [State of emergency as a technique of rule of the Nazi regime], in: Funke, Hitler, Deutschland, 30-45, 30-31

${ }^{287}$ Quoted by Ullrich, Hitler I, 354

288 Roehl, Abyss, 969; Hartmut Pogge von Strandtmann, Immanuel Geiss, Die Erforderlichkeit des Unmoeglichen. Deutschland am Vorabend des Ersten Weltkriegs [The necessity of the impossible. Germany on the eve of the First World War] (Frankfurt/M.: Europaeische Verlagsanstalt, 1965), 5-45
} 
in 1933. During the July Crisis in 1914 Wilhelm made aggressive statements publicly ${ }^{289}$, that critized his father's Government and threatened to disturb the 'indirect provocation' scenario the German leadership had adopted to facilitate the Austro-Hungarian ultimatum to Serbia, while officially trying to seem not involved. Bethmann Hollweg had to ask the Kaiser again to reprimand his son, because his utterances "might not only help our opponents but also produce a result the opposite of that intended (...)." 290

The key point - that cannot be stressed enough - for the Crown Prince' engagement against the republic and for the Nazis - like for the other National Conservatives - was the fact that Germany had surprisingly lost the First World War, the Hohenzollern abdicated and the republic accepted the Versailles Treaty that was based on the premise that Germany had started the war in 1914. In several publications ${ }^{291}$ (which are not mentioned in any of the reports) Wilhelm joined the German 'innocence' campaign against the alleged Kriegsschuldluege (war-guilt lie), that was started by the German Foreign Office in $1919^{292}$ to drive a wedge between the Allies, challenge Article 231 in order to bring down the whole Treaty. In addition, Wilhelm and his friends were uncompromising foes of the Weimar Republic combining their agitation against democracy with the German obligations to pay reparations for the damages Germany had caused. The crucial point in all of this was the unleashing of the war in 1914 and the non-acceptance of responsibility when the war turned into a defeat. And Wilhelm, as his publications demonstrate, chose - like his father and other

\footnotetext{
289 Roehl, Abyss, 1032

${ }^{290}$ Roehl, Abyss, 1032

${ }^{291}$ Kronprinz Wilhelm, Erinnerungen [Memoirs] (Stuttgart: J. B. Cotta, 1922); Kronprinz Wilhelm, Ich suche die Wahrheit. Ein Buch zur Kriegsschuldfrage [I search for the Truth, a Study on War-Guilt] (Stuttgart: J. B. Cotta, 1925)

292 Regarding the German 'innocence' campaign there are only a few studies available, Hermann J. Wittgens, The German Foreign Office campaign against the Versailles Treaty, an examination of the activities of the Kriegsschuldreferat in the United States (Ph. D. diss., University of Washington, 1970); Holger H. Herwig, "Clio Deceived: Patrotic Self-Censorship in Germany after the Great War", International Security 12, no. 1 (1987): 5-44; Erich J. C. Hahn, “The German Foreign Ministry and the Question of War Guilt in 1918-1919”, in: German Nationalism and the European Response, ed. Carole Fink, Isabel Hull, James McGregor Knox (Norman: University of Oklahoma Press, 1985): 43-70; Ulrich Heinemann, Die verdraengte Niederlage. Politische Oeffentlichkeit und Kriegsschuldfrage in der Weimarer Republik [The suppressed defeat. Public Discussion and the War Guilt Question in the Weimar Republic] (Goettingen: Vandenhoeck \& Ruprecht, 1983); Immanuel Geiss, "Die manipulierte Kriegsschuldfrage" [The manipulated War-Guilt Question], in: Militaergeschichtliche Mitteilungen 34, no. 2 (1983); Gottlieb von Jagow (1863-1935) und sein Umfeld. Ein kaiserlicher Spitzendiplomat zwischen Erstem Weltkrieg und Kriegs(un)schuldforschung [Gottlieb von Jagow (1863-1935) and his sphere. A top imperial diplomat between World War I and War Guilt Research], ed. Reinhold Zilch (Berlin: Trafo Wissenschaftsverlag, 2020)
} 
National Conservatives at the time - defiance over reality and paved the way for right-wing radicals like the Nazis. ${ }^{293}$

The Crown Prince and the other National Conservatives did not want to realize that the German decision to go to war in 1914 was unnecessary and wrong from the start. Germany unleashed a 'war of illusions' and a war of 'false hope' implying that the country would be able to force its rule upon the neighboring countries in Europe. Germany's unleashing of the war in 1914 was based on a strategy of 'deception' attacking and overwhelming Germany's neighbors to dominate all of Europe - pretending that Germany had to defend itself against an 'ambush' by Russia and France - and was based on the false calculation of military superiority that - sooner or later - was bound to fail against the superior resources of the Allies. ${ }^{294}$ Even after the defeat in 1918, Germany's elites and the Crown Prince were looking for excuses not to acknowledge these issues, and Wilhelm and a lot of people rather clung to the antiVersailles campaign of the Foreign Office that blamed the Allies. This was continued after the seizure of power in 1933 until Hitler finally pulled the signature to the Versailles Treaty in 1937 and initiated his renewed program of war against Germany's neighbors again under the pretext of 'defense'. ${ }^{295}$

Wilhelm's so-called 'search for the truth'296 about the unleashing of the war in 1914 - as one of his studies was called - was based only on the selective view of the German innocence campaign that omitted important facts just like the 'expert opinions' in favor of the Hohenzollern and other historiography that is still agitating against Versailles and complaining about Germany's loss of 'sovereignty', blaming the Allies for Hitler's seizure of power even a hundred years later today. ${ }^{297}$ The Crown Prince, in sending Hitler telegrams of congratulations in 1939-40, was overlooking the fact that all the new conquests - like those between 1914-18 - were based on illusions with the difference that this time Germany's adversaries would not be deceived again. After the initial success of the Nazis the Allies again

293 Eckart Conze, "Verhasster Vertrag, Versailles als Propagandawaffe gegen die Weimarer Republik" [The hated Treaty, Versailles as a Weapon of Propaganda against the Weimar Republic], in: Aus Politik und Zeitgeschichte 69 (2019): 45-49

${ }^{294}$ In a rare case of realism, Hans Delbrueck, "Die strategische Grundfrage des Welkrieges"[The strategically decisive question of the World War], in: Preussische Jahrbuecher 183 (1921): 289-308

${ }^{295}$ Hamerow, Wolf's Lair, 19-82

${ }^{296}$ Crown Prince Wilhelm's study is called, Ich suche die Wahrheit ('I search for the Truth')

${ }^{297}$ Peter Hoeres, “Versailler Vertrag: ein Frieden, der keiner war" [The Versailles Treaty, a peace that wasn't], in: Aus Politik und Zeitgeschichte 69 (2019): 38-44; also the revisionist manifesto, Dominik Geppert, Soenke Neitzel, Cora Stephan, Thomas Weber, "Warum Deutschland nicht allein Schuld ist" [Why Germany is not guilty by itself], Welt.de, January 4, 2014 
brought their massive resources to bear to thwart Germany's second "Griff nach der Weltmacht"'298 ('quest for World Power') which ended this time with the 'unconditional surrender' of the country, and cost again millions of lives on both sides.

In the end, the Crown Prince - like other National Conservatives - turned out to be more astute than the Nazis. Wilhelm simply avoided the resistance against Hitler, the Goetterdaemmerung of 1945 and, ignoring those major events, pretended - even after the disaster of another lost war - that nothing had happened. The keyword after 1945 was initially not Aufklaerung ('enlightenment') but Verdraengung ('suppression') of the past, the National Conservatives as well as the Nazis both had an interest in, which is somewhat understandable looking at the seriousness of their crimes. Both parties had of course an interest to minimize their involvement and push it on the major 'criminals', who obviously lead the effort. Wilhelm survived the 'catastrophe' of 1945 like his brethren as somebody who had - as the majority of Germans - 'supported' Hitler, and pretended, he did not know anything about the domestic and foreign victims that this 'experiment' had caused. But even after 1945, the Crown Prince felt an allegiance to the Fuehrer, praising his speech on the 'Day of Potsdam,299 that explains best German history, the day where National Conservatives and the Nazis reaffirmed and deepened their alliance to start working on the 'national cause'. After 1945, Wilhelm was probably puzzled over the fact - after the 'promising' start of 1933 - that the alliance with the Nazis ended up in such a colossal failure.

What the conservatives and the Crown Prince refused to accept, is the fact that Germany's return as a Great Power, going back to the coveted sovereignty before 1914, was undesirable and would cost millions of lives even besides the Holocaust. ${ }^{300}$ The state of war was not a natural thing, although Wilhelm glorified it as a 'necessary' circumstance, that was justified and deserved his support, even before 1914. ${ }^{301}$ The idea that violence, war, and conquest would be considered 'normal' between people and countries, like a 'natural catastrophe' that is unavoidable, may be a justification after the fact or an ideology of the Nazis ${ }^{302}$, but should

\footnotetext{
298 This is the title of the study of Fritz Fischer, Griff nach der Weltmacht (Duesseldorf: Droste, 1961) that finally changed the discussion about the First World War forever [engl. transl.: Germany's aims in the First World War (New York: W. W. Norton \& Co., 1967)]

${ }^{299}$ Malinowski, Report, 42

300 Dieter Pohl, "Der Holocaust und die anderen NS-Verbrechen: Wechselwirkungen und Zusammenhaenge" [The Holocaust and other crimes, Interactions and Context], in: Der Holocaust, Ergebnisse und neue Fragen der Forschung, ed. Frank Bajohr, Andrea Loew (Frankfurt/M.: Fischer, 2015): 124-140

${ }^{301}$ Kronprinz Wilhelm (Ed.), Deutschland in Waffen [Germany with Arms] (Stuttgart: DVA, 1913)

302 Regarding the NS-ideology of violence and war, Broszat, "Zweiter Weltkrieg”, 40-43
} 
not serve as a positive guidance for domestic and foreign relations of any 'civilized' country. That Wilhelm was also responsible for the 'catastrophe' in Europe may have occurred to him sometimes, but because he was not directly involved, he felt like a spectator, suppressing these uncomfortable thoughts, believing in his innocence, and - like the rest of Germany carried on and complained about the downsides of the occupation regime. ${ }^{303}$ Whatever the Fuehrer had done, in their mind, was not 'all' wrong, trying to separate the 'successes' of a Grossdeutschland from the 'methods' of the Nazis, guided by a false nationalism, which valued the invasion and dominance of foreign countries implemented and accompanied by the doctrine of racial superiority that was praised as a positive accomplishment.

After 1945 the National Conservatives were appalled about the measures ${ }^{304}$ the Allies took after 'unconditional surrender', not comprehending the danger Germany had meant for Europe and the World. It took another generation to leave the negative connotation of Versailles behind and acknowledge what had really happened. Meanwhile, it is well-known that after 1949 and the initial 'brush' with the 'truth' during the IMT-trials, the old, National Conservative elites ${ }^{305}$ returned with the stipulation that they were the real victims of Nazism and were never involved or supported Hitler and his regime, creating the 'myth' that the Nazis fell from the sky and had hijacked the German Government in 1933 ${ }^{306}$, inventing the "minimal guilt thesis"307 that - in a nutshell - all the National Conservative supporters of Hitler were mere Mitlaeufer, a myth Clark and Machtan are now reviving. Whatever mistakes the Allies had made after 1918, this time they made sure that Germany would not get off the hook without fundamental changes.

\footnotetext{
${ }^{303}$ Jonas, Kronprinz, 281-310

${ }^{304}$ This time the Allies forced Germany to surrender 'unconditionally', changing the political structures that had helped Germany to unleash two World Wars, and established their own tribunal (IMT), that - in contrast to the German trials in Leipzig in the 1920s - prosecuted war crimes initiating first a main trial against the top Nazielite and then twelve follow-on trials against those people who became Hitler's accomplices and executors, Der Nationalsozialismus vor Gericht: die allierten Prozesse gegen Kriegsverbrecher und Soldaten, 1943 - 1952 [National Socialism in Court, Allied Trials of War Criminals and Soldiers, 1943-1952], ed. Gerd R. Ueberschaer (Frankfurt/M.: Fischer, 1999)

${ }^{305}$ Regarding the return of the old elites in Germany after 1949 and the exculpation of the Nazi-crimes, Der halbierte Rechtsstaat, Demokratie und Recht in der frühen Bundesrepublik und die Integration von NSFunktionseliten [The halved Rule of Law, Democracy and Justice in the early Federal Republic and the Integration of Nazi functional Elites], ed. Sonja Begalke, Claudia Fröhlich, Stephan A. Glienke (Baden Baden: Nomos, 2015); Norbert Frei, Vergangenheitspolitik, die Anfänge der Bundesrepublik und die NS-Vergangenheit (Muenchen: C. H. Beck, 1996); [engl. transl., Adenauer's Germany and the Nazi Past: The Politics of Amnesty and Integration (New York: Columbia University Press, 2002)]

${ }^{306}$ Frei, Adenauer's Germany, 312

307 Thomas W. Maulucci, "German Diplomats and the Myth of the Two Foreign Office", in: A Nazi Past: recasting German identity in postwar Europe, ed. David A. Messenger, Katrin Paehler (Lexington, KY: The University Press of Kentucky, 2015): 139-167, 139
} 
The questions remains, what did the Crown Prince needed to do - other than what he did that would qualify - in Machtan's and Clark's eyes - that Wilhelm 'dignificnatly advanced' National Socialism? Becoming a minister - like Hugenberg - in his cabinet, being directly a part of the the seizure of power and supporting Hitler more openly than he did? Was it therefore ok to support Hitler and the Nazis like the National Conservatives did back then? Or did Wilhelm had to be the Kaiser of Germany at the time after a successful restoration of the monarchy under the Nazis? If that would have been the case, and Wilhelm as the Kaiser of Germany would have tolerated the Nazi crimes as they happened and him being their fig leaf, he would have been one of the main war criminals at the trial at Nuremberg and probably would not have been acquitted. In a nutshell: the Crown Prince was lucky that Hitler resisted all projects of restoring the monarchy with Wilhelm as the new Kaiser, because otherwise he would not have gotten away after 1945 as easily as he did. But now, as we can see clearly, the Crown Prince's behavior in supporting Hitler should be a matter of compensation so that also his support for the Nazis is rewarded at the same time? Is that why some historians characterize him only as a Mitlaeufer that will excuse similar behavior as the right thing to do at the time and as probably all supporters could come up with excuses to act that way?

Hitler - in a certain way - in refusing Wilhelm's advances protected his future as a 'normal citizen' who - as Clark and Machtan have called him - was only a mere Mitlaeufer, an unscrupulous fellow traveler like any other supporter in Germany, that just agreed with Hitler on $90 \%$ of the Nazi ideology, that just wanted a 'normal' dictatorship that eliminated all the dissenters and a 'normal' war of revenge against the neighbors to achieve the German goals, they were unable to accomplish in the First Wold War. For these goals he just had to support and significantly advance the Nazis, because nobody else was as ruthless to do the job thoroughly, as Wilhelm by himself acknowleged. He knew what he was getting into and that's why he supported Hitler and not one of the National Conservatives. And now - 70 years later - we cannot figure out if this person was supporting and 'significantly advancing' Hitler? The good news is: Machtans study is a clear sign that the deeper the historian is digging, nobody is able to find anything that would exonerate the Crown Prince or turn him into a part of the resistance and that it is rather to the opposite, considering that all the new materials show Wilhelm's relentless support for Hitler and the Nazis.

Today, 75 years later, two 'expert opinions' confirm that Wilhelm and his brethren did not support and 'significantly advance' National Socialism, that his responsibility was close to zero and that he was in opposition and resistance of the Nazi-regime or was only a mere 
Mitlaeufer. ${ }^{308}$ This late Persilschein tries to set the clock back to the 1950 s and conveniently overlooks the fact, that without people like Wilhelm, Hitler would have never come to power. Fortunately, we know better today and do not have to rely on reports, that are showing history with distortions and insisting on an alternative that never existed.

${ }^{308}$ Clark, Report, 16: "In those years the Crown Prince became a pure fellow traveler (Mitlaeufer)." 